$$
D \circ f / O R / 22207 \ldots 1
$$

\title{
Ground-Water Flow and Ground- and Surface-Water Interaction at the Weldon Spring Quarry, St. Charles County, Missouri
}

By Jeffrey L. Imes and Michael J. Kleeschulte

U.S. GEOLOGICAL SURVEY

Water-Resources Investigations Report 96-4279

Prepared in cooperation with the U.S. DEPARTMENT OF ENERGY

\author{
MASTER \\ Rolla, Missouri \\ 1997

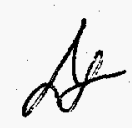

BSTTRIBUTION OF THS DOCUMENT IS UNLMMTED

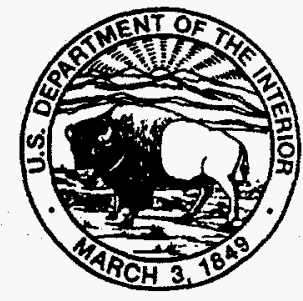




\section{U.S. DEPARTMENT OF THE INTERIOR BRUCE BABBITT, Secretary}

U.S. GEOLOGICAL SURVEY

Gordon P. Eaton, Director

The use of firm, trade, and brand names in this report is for identification purposes only and does not constitute endorsement by the U.S. Geological Survey.

For additional information write to:

Copies of this report can be purchased from:

District Chief

U.S. Geological Survey

1400 Independence Road

Mail Stop 100

Rolla, MO 65401
U.S. Geological Survey

Branch of Information Services

Box 25286

Denver, CO 80225-0286 


\section{DISCLAIMER}

Portions of this document may be illegible electronic image products. Images are produced from the best available original document. 


\section{CONTENTS}

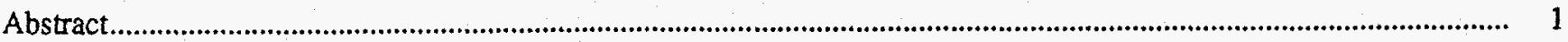

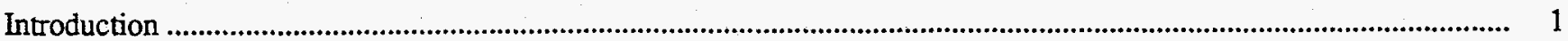

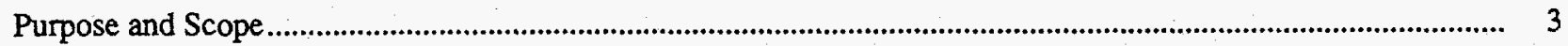

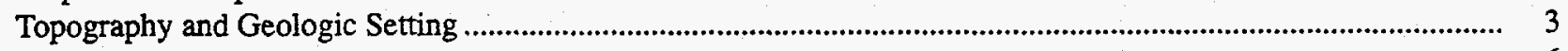

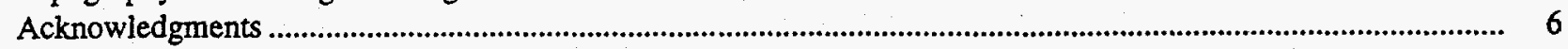

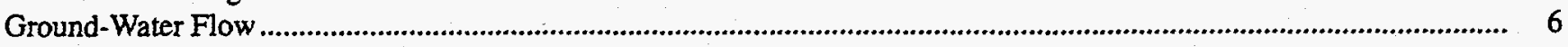

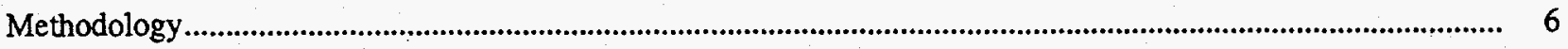

Piezometer and Staff-Gage Network Design ................................................................................................... 12

Ground- and Surface-Water-Level Measurements ............................................................................................. 14

Lateral Flow Interpreted from Potentiometric Maps ................................................................................................ 16

Flow Interpreted from Hydraulic-Head Differences along Two Sections ............................................................. 21

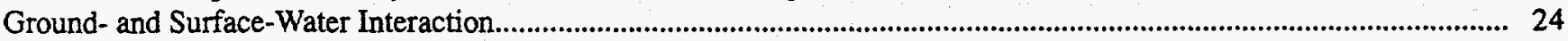

Recharge of the Alluvial Aquifer by Femme Osage Slough .............................................................................. 27

Ground-Water Discharge to Little Femme Osage Creek ............................................................................................ 29

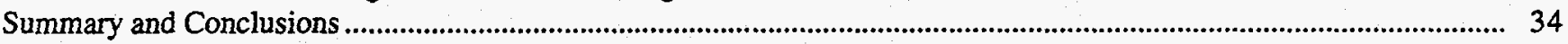

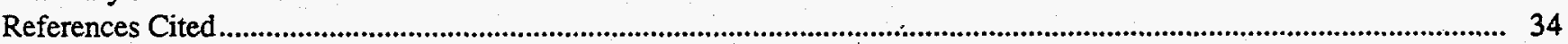

\section{FIGURES}

1.-3. Maps showing:

1. Boundary of U.S. Army property and U.S. Department of Energy chemical plant site and location of the Weldon Spring quarry, Weldon Spring, Missouri.

2. Location of the Weldon Spring quarry, wells in the St. Charles County well field, and area where uranium has been detected above background concentrations.

3. Topography of the upland bedrock areas and the Missouri River alluvial plain near the Weldon Spring quarry

4. Generalized stratigraphic column with descriptions of the lithologic and hydrologic properties of the geologic formations present in southern St. Charles County

5. Map showing location of piezometers and staff gages installed to monitor water levels

6. Map showing location of water-quality monitoring wells included in the water-level monitoring network ....... $\quad 13$

7.-22. Maps showing water-table altitudes in the bedrock and the alluvial aquifer near the Weldon Spring quarry,

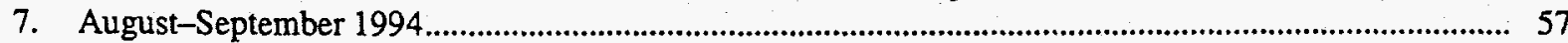

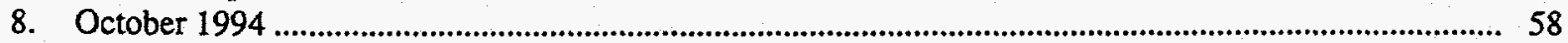

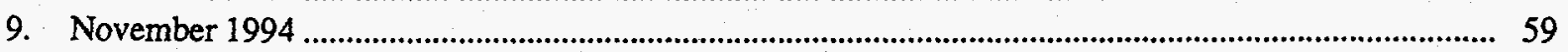

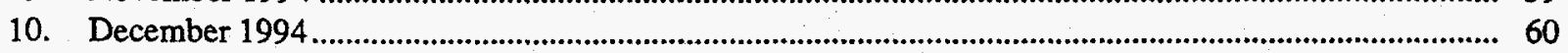

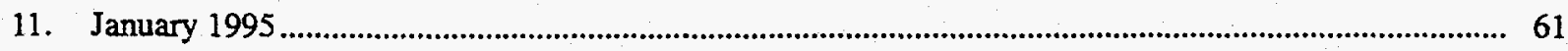

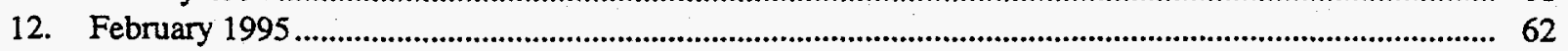

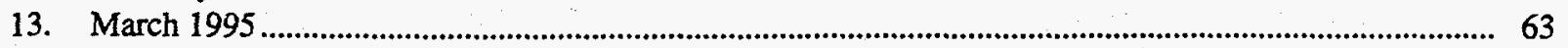

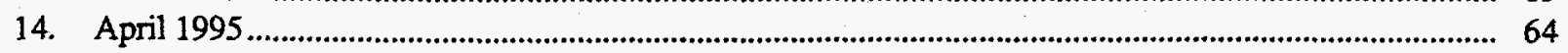

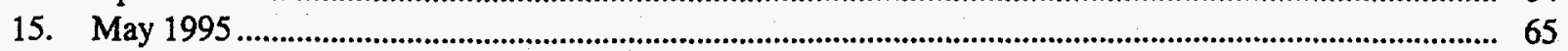

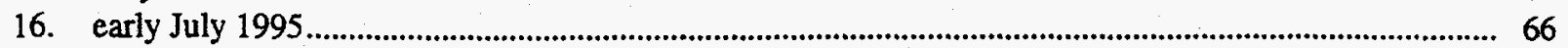

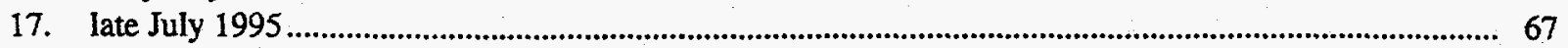

18. August 1995

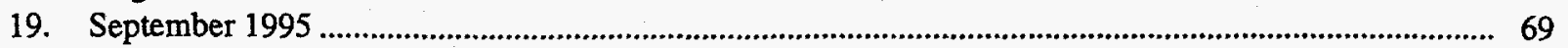

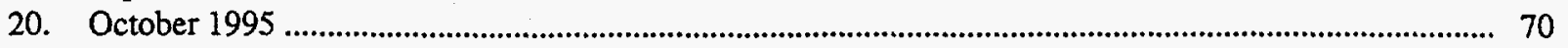

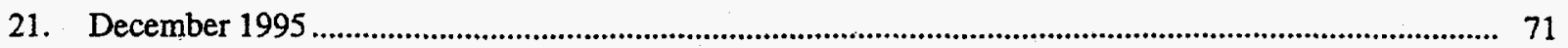

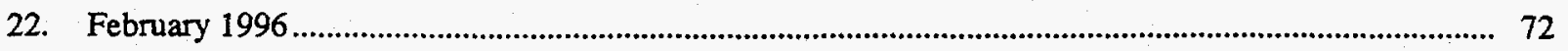




\section{FIGURES-Continued}

23. Map showing potentiometric surface of the coarse-grained basal part of the alluvial aquifer, Decernber 1995

24. Map showing potentiometric surface of the coarse-grained basal part of the alluvial aquifer, February 1996

25.-27. Graphs showing:

25. Vertical hydraulic-head differences along cross section $A-A^{\prime}$ from the Weldon Spring quarry to the Missouri River alluvial aquifer, February 1996

26. Vertical hydraulic-head differences along cross section B-B' from the upland area northeast of the Weldon Spring quarry to the Missouri River alluvial aquifer, February 1996

27. Daily mean water-level altitudes in piezometers WSQ-S12 and WSQ-S25 and monitoring well MW-1019 and at gage WSG-SG5 (Femme Osage Slough).

28.-30. Maps showing location of seepage-run measurements on Little Femme Osage Creek,

28. August 24, 1994

29. March 17, 1995

30. October 26,1995

\section{TABLES}

1. Site location and construction data for piezometers, monitoring wells, and staff gages in the water-level monitoring network

2. Surveyed and interpolated altitudes along the Missouri Department of Conservation boat ramp at the Missouri River

3. Monthly and bi-monthly altitude of water levels in piezometers, selected monitoring wells, and staff gages in the water-level monitoring network

4. Daily mean water-level altitudes for piezometer WSQ-S12

5. Daily mean water-level altitudes for piezometer WSQ-S19

6. Daily mean water-level altitudes for piezometer WSQ-S25

7. Daily mean water-level altitudes for piezometer WSQ-B4.

8. Daily mean water-level altitudes for monitoring well MW-1019

9. Daily mean stage for Femme Osage Slough

10. Stream-discharge measurements on Little Femme Osage Creek (August 24, 1994, March 17, 1995, and October 26, 1995) 


\title{
Ground-Water Flow and Ground- and Surface-Water Interaction at the Weldon Spring Quarry, St. Charles County, Missouri
}

\author{
By Jeffrey L. Imes and Michael J. Kleeschulte
}

\begin{abstract}
Ground-water-level measurements were made in 37 piezometers and 19 monitoring wells during a 19-month period to assess the potential for ground-water flow from an abandoned quarry to the nearby St. Charles County well field, which withdraws water from the base of the alluvial aquifer. From 1957 to 1966 , low-level radioactive waste products from the Weldon Spring chemical plant were placed in the quarry a few hundred feet north of the Missouri River alluvial plain. Uranium-based contaminants subsequently were detected in alluvial ground water south of the quarry.
\end{abstract}

During all but flood conditions, lateral ground-water flow in the bedrock from the quarry, as interpreted from water-table maps, generally is southwest toward Little Femme Osage Creek or south into the alluvial aquifer. After entering the alluvial aquifer, the ground water flows southeast to east toward a ground-water depression presumably produced by pumping at the St. Charles County well field. The depression position varies depending on the Missouri River stage and probably the number and location of active wells in the St. Charles County well field.

Vertical ground-water flow as determined from ground-water-level measurements in piezometers and monitoring wells completed in different horizons in the bedrock and the alluvial aquifer indicate that water from the quarry moves downward into the Plattin Formation and laterally toward and into the base of the alluvial aquifer. Ground water also flows from the alluvial aquifer water table downward into more permeable gravel and sand deposits at the base of the alluvial aquifer.

The Femme Osage Slough is a source of recharge to the alluvial aquifer except during extreme conditions caused by an unusually high Missouri River stage (above 455 feet). Water levels in Femme Osage Slough typically are higher than water levels in the alluvial aquifer beneath the slough. Gains or losses of streamflow in Little Femme Osage Creek near the abandoned quarry are minimal. Therefore, the exchange of water between the bedrock aquifer and Little Femme Osage Creek is minimal.

\section{INTRODUCTION}

The Weldon Spring chemical plant in southern St. Charles County, Missouri (fig. 1), was operated from 1957 to 1966 to process uranium-ore concentrates and recycled scrap to obtain uranium tetrafluoride, uranium trioxide, and pure uranium metal (Kleeschulte and Emmett, 1987). Low-level radioactive waste products from the chemical plant, which consisted primarily of accumulated contaminated solids and radioactive residues, were transported to an abandoned limestone quarry, known as the Weldon Spring quarry (fig. 1), hereinafter referred to in this report as the quarry, located south of State Highway 


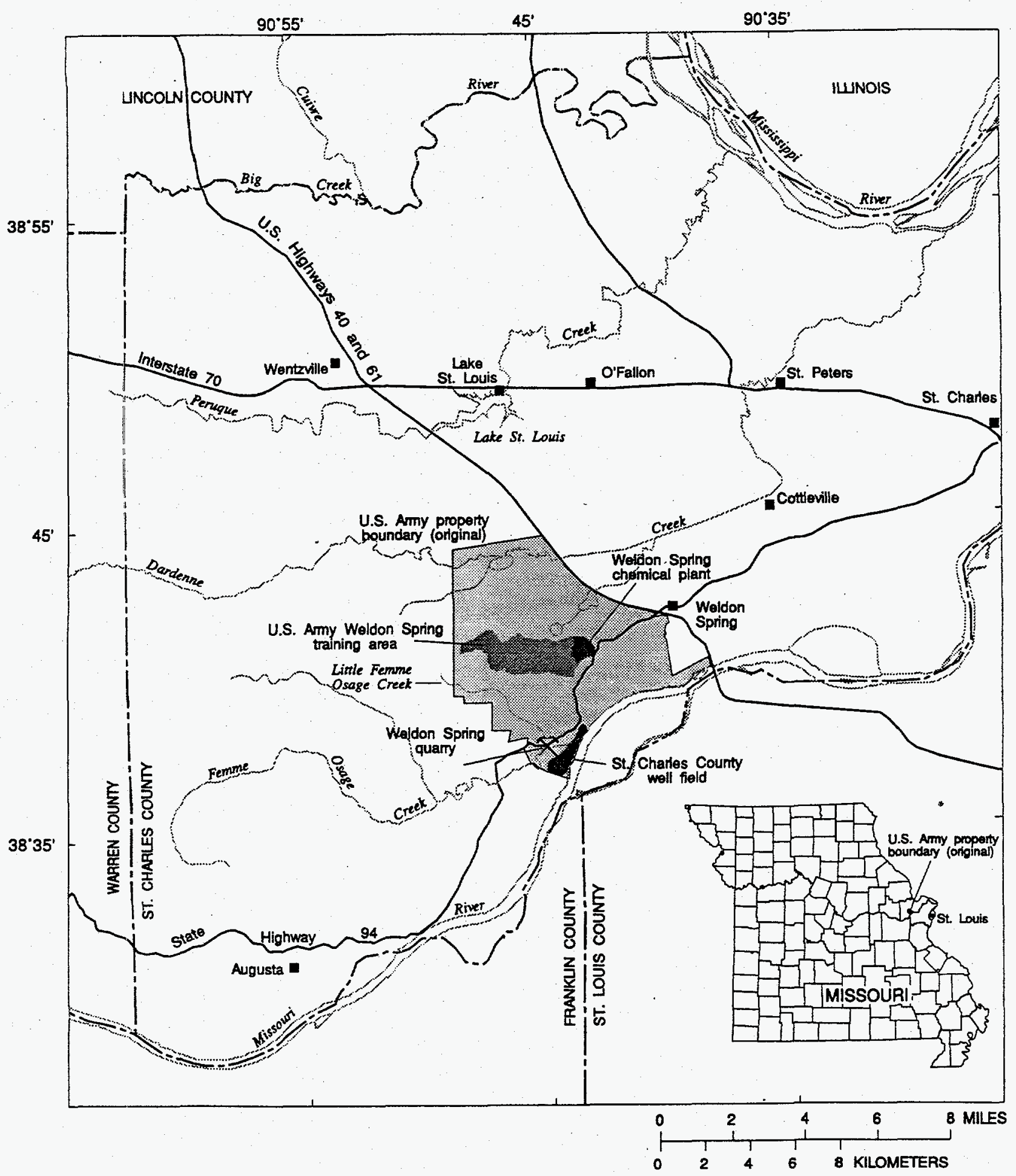

Figure 1. Boundary of U.S. Amy property and U.S. Department of Energy chemical plant site and location of the Weldon Spring quarry, Weldon Spring, Missouri. 
94, about $3 \mathrm{mi}$ (miles) southwest of the chemical plant. The quarry, which was cut into permeable, fractured rocks of the Kimmswick Limestone and the upper 15 to $20 \mathrm{ft}$ (feet) of the Decorah Formation, is a few hundred feet north of bedrock bluffs overlooking the Missouri River alluvial plain. The quarry is steep-walled to the north, east, and south and opens to the west onto the narrow alluvial plain of Little Femme Osage Creek. With the accumulated wastes, the quarry floor was raised from an altitude of about 435 to $465 \mathrm{ft}$ above sea level or approximately the same level as the Missouri River alluvial plain south of the quarry.

The first load of an estimated $95,000 \mathrm{yd}^{3}$ (cubic yards) of contaminated materials consisting of structural debris, drummed and unconfined wastes, process equipment, soils, and sludges was transported from the quarry in May 1993 (U.S. Department of Energy, 1994). Waste removal from the quarry has again lowered the altitude of the quarry floor back to the original altitude, and currently (1996), the lowest point in the quarry is at an altitude of $435 \mathrm{ft}$ (Bill Goldkamp, Project Management Contractor, written commun., 1996). This level of the floor is beneath the water table and is shown as the quarry pond on figure 2 . This part of the quarry remains flooded unless water is removed by pumping.

The St. Charles County well field withdraws water from the base of the Missouri River alluvial aquifer south and east of the quarry (figs. 1,2). Wells 2 through 8 are active. The construction of these wells is similar; they range from 104 to $110 \mathrm{ft}$ deep, are open to the base of the alluvial aquifer through a $40-\mathrm{ft}$ screen at the bottom of the well, and are cased from the screen to land surface (Mugel, 1993). Because of the potential for migration of uranium-based contaminants from the quarry into the well field, a water-sampling program was initiated to collect samples from the alluvial aquifer that supplies water to the well field. Ground-water samples collected during 1985 and 1986 south of the quarry and north of Little Femme Osage and Femme Osage Sloughs (fig. 2) had above-background uranium concentrations (fig. 2) ranging from 47 to $4,500 \mu \mathrm{g} / \mathrm{L}$ (micrograms per liter). Elevated concentrations of uranium (as large as 77 $\mu \mathrm{g} / \mathrm{L}$ ) also were detected in surface-water samples from the western section of Femme Osage Slough near the quarry. These data indicated that uranium had migrated southward from the quarry area (Kleeschulte and Emmett, 1987). However, water samples collected from alluvial wells south of the slough had uranium concentrations at background concentrations ranging from 0.4 to $4.2 \mu \mathrm{g} / \mathrm{L}$ (Kleeschulte and others, 1986).

\section{Purpose and Scope}

The detection of uranium-based contaminants in alluvial ground water south of the quarry indicated the possibility that contaminated ground water could migrate into the St. Charles County well field. However, the movement and fate of contaminants transported from the quarry by ground water was not completely understood. Because of uncertainties regarding the potential of contaminant migration, a study was begun in March 1994 by the U.S. Geological Survey, in cooperation with the U.S. Department of Energy, to address these concerns. This report presents the results of that study that ended in September 1996, defines the vertical and lateral movement of ground water from the quarry to discharge areas in the Missouri River alluvial aquifer, and assesses ground- and surface-water interaction between the quarry area and Femme Osage Slough, Little Femme Osage Slough, and in the alluvial aquifer near the quarry.

This report also provides: a ground-water flowpath analysis from the quarry; data to support remedial actions associated with the removal of uranium-contaminated material from the quarry; and data that can aid in the construction and calibration of a digital ground-water flow model to simulate ground-water flow in the quarry and the nearby alluvial aquifer. The geohydrologic data were collected from a monitoring network consisting of piezometers and surface-water staff gages designed to provide ground-water-level monitoring in the quarry area and in the alluvial aquifer south and east of the quarry.

\section{Topography and Geologic Setting}

Land-surface altitudes in the study area (fig. 3) range from 450 to $580 \mathrm{ft}$ above sea level. A ridge south of the quarry forms the bluff overlooking the Missouri River alluvial plain. The quarry was excavated into the west end of this ridge about $0.25 \mathrm{mi}$ east of the Little Femme Osage Creek. The vertical bluff face exposes as much as $80 \mathrm{ft}$ of limestone bedrock and marks the northern erosional limit of the Missouri River. The Missouri River alluvial plain south of the bluff is flat, and altitudes range from 450 to $460 \mathrm{ft}$ above sea level. Altitudes are about $10 \mathrm{ft}$ lower in 


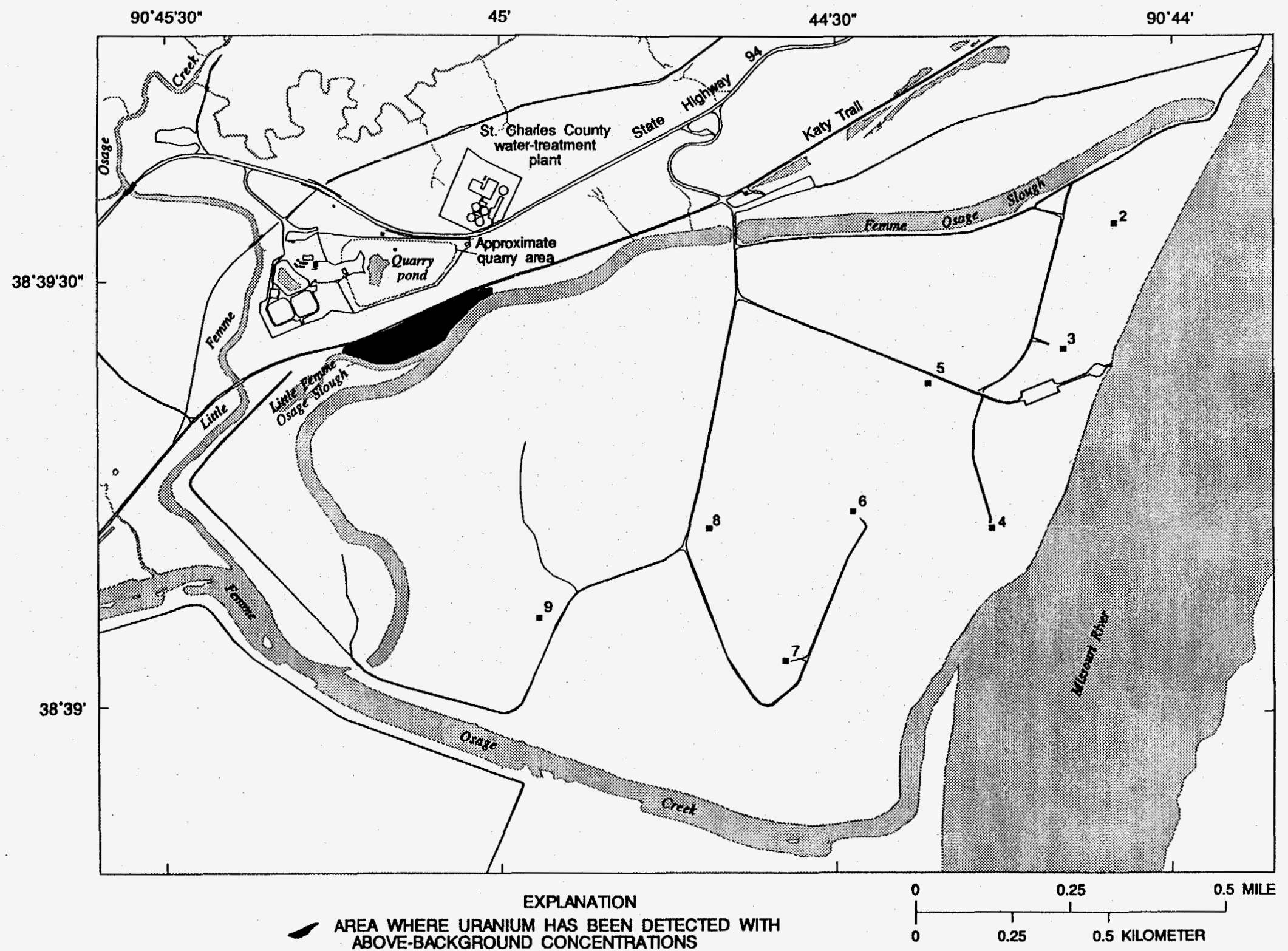

$\because$ WeLL IN THE ST. ChaRles COUNTY WeLl fieL AND NUMBER

Figure 2. Location of the Weldon Spring quarry, wells in the St. Charles County well field, and area where uranium has been detected above background concentrations. 


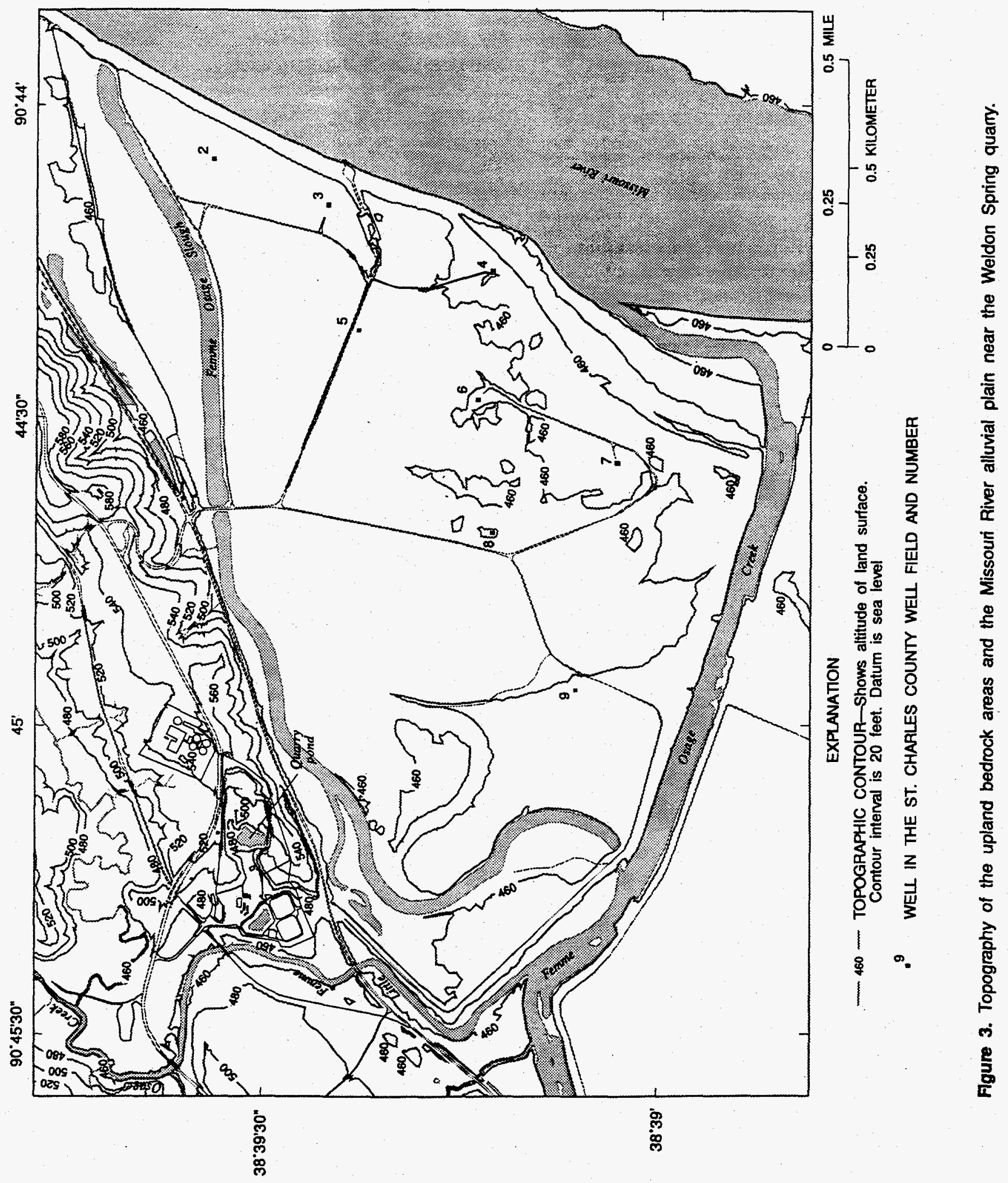


abandoned channels and sloughs and about $10 \mathrm{ft}$ higher along the man-made levee, constructed to protect the alluvial plain from floodwaters.

Bedrock geologic units from younger to older formations in the vicinity of the quarry are the Kimmswick Limestone, Decorah Formation, and Plattin Formation (fig. 4). The uppermost Kimmswick Limestone is covered by thin clayey soils and was the source rock during the production years of quarry operation. The original quarry floor exposed the upper part of the Decorah Formation, a predominantly thinly bedded limestone. The altitude of this part of the quarry floor is about $435 \mathrm{ft}$ and is near the top of the predominantly limestone Plattin Formation, which underlies the 30-ft thick Decorah Formation. The base of the Decorah Formation and upper part of the Plattin Formation commonly are characterized by the presence of metabentonite beds, which may impede the downward movement of ground water. The primary permeability of the Plattin Formation typically is small and fractures are few. The formation permeability is higher where small fractures are present, offering alternate routes for ground-water flow.

Unconsolidated sediment forming the Missouri River alluvium generally is composed of fine-grained silt or clay near the surface grading downward to coarser-grained sand and gravel near the base of the alluvium. During drilling of piezometers in the alluvial aquifer, a thick (15-20 ft) layer of blue viscous clay was observed south of the quarry along the southern side of the Fiemme Osage Slough. This clay layer seemed to be localized in this area. Silt was a more common surficial material encountered in other parts of the alluvium.

\section{Acknowledgments}

The authors acknowledge the cooperation of Bill Goldkamp, Project Management Contractor, who served as a liaison between the U.S. Geological Survey, the drilling contractors, and the drilling personnel. $\mathrm{He}$ managed the numerous modifications to the drilling specifications and informed us about the drilling status of the monitoring wells. Acknowledgment also is given to the Missouri Department of Conservation for permission to install the piezometers on public land and for allowing vehicular access to the abandoned Missouri-Kansas-Texas Railroad embankment locally known as the Katy Trail (fig. 2). Without their cooperation, the data could not have been collected.

\section{GROUND-WATER FLOW}

The sharp termination of bedrock at land surface evident by the bluff overlooking the Missouri River alluvial plain and the presence of the Missouri River, smaller tributary streams, the thick alluvial deposits, and the St. Charles County well field all in a limited area add to the complexity of ground-water flow in the quarry area. The combined effects of these factors caused uncertainty in the conceptual model of groundwater flow for the area. Therefore, a piezometer and staff-gage monitoring network was designed to determine both the lateral and vertical ground-water flow directions for the area, which will support future digital-modeling efforts.

\section{Methodology}

The piezometer and staff-gage network was designed to monitor water levels at the water-table surface, at various depths (as deep as about $120 \mathrm{ft}$ ) in the bedrock and alluvial aquifers, and in surface-water bodies. This section describes techniques and the rationale that were used to create the network and collect the data. The network was designed to be flexible and monitor ground- and surface-water levels throughout different seasonal conditions. Water levels in some of the piezometers were measured monthly, whereas other piezometers had continuous digital recorders that monitored water levels hourly.

The shallow alluvial piezometers and staff gages (fig. 5) were installed by U.S. Geological Survey personnel, and a detailed discussion of the construction of these piezometers is provided. Several deeper piezometers also were needed as a result of this project. Because monitoring wells already existed in the quarry area and in the Missouri River alluvium prior to the start of this project, the monitoring network was designed to incorporate as many existing monitoring wells as possible to reduce costs. The deep piezometers that had to be drilled because an adequate substitute was not available were installed by the Project Management Contractor. Construction data for all piezometers and monitoring wells are summarized in table 1.

A major problem in the construction of the monitoring network was that the drilling of some piezometers was substantially delayed. Drilling of piezometers was scheduled to begin in March 1994; however, a combination of administrative delays related to piezom- 


\begin{tabular}{|c|c|c|c|c|c|c|}
\hline $\begin{array}{l}E \\
\text { है } \\
\text { s } \\
\end{array}$ & 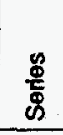 & $\begin{array}{l}\text { Stratigraphic } \\
\text { unit }\end{array}$ & $\begin{array}{l}\text { Range of } \\
\text { thickness, } \\
\text { in foet }\end{array}$ & $\begin{array}{l}\text { Lithologic and } \\
\text { physical properties }\end{array}$ & 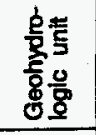 & $\begin{array}{l}\text { Hydrologic properties } \\
\text { and remanks }\end{array}$ \\
\hline \multirow{3}{*}{ 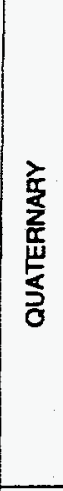 } & \multirow{2}{*}{ 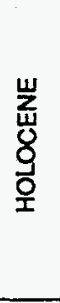 } & \multirow[t]{2}{*}{ Aluvium } & $0-65$ & $\begin{array}{l}\text { Gravelly, sity loam over } \\
\text { occasionally gravelly, silty } \\
\text { clay loam }\end{array}$ & \multirow{2}{*}{ 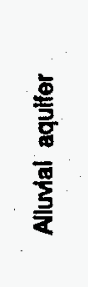 } & $\begin{array}{l}\text { Deposits underlie tributaries } \\
\text { to the Missouri and } \\
\text { Mississippi Rivers }\end{array}$ \\
\hline & & & 0.120 & $\begin{array}{l}\text { Silty loam, clay, and sand } \\
\text { over sand, gravelly sand }\end{array}$ & & $\begin{array}{l}\text { Deposits underlying the } \\
\text { Missouri and Mississippi } \\
\text { River foodplains generally } \\
\text { yield large quantities of } \\
\text { water to wolls (600-2,600 } \\
\text { gallons per minute) }\end{array}$ \\
\hline & $\frac{\sum_{1}^{W}}{8}$ & Loess & 0.11 & $\begin{array}{l}\text { Slity clay, slity loam, clay, } \\
\text { or loam over residuum } \\
\text { or bedrock, or both }\end{array}$ & 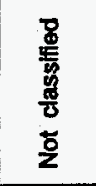 & $\begin{array}{l}\text { Yelds littie water to wells } \\
\text { (less than } 5 \text { gallons per } \\
\text { minute) }\end{array}$ \\
\hline \multirow{5}{*}{$\begin{array}{l}\frac{3}{5} \\
\frac{0}{5} \\
\frac{0}{5} \\
\frac{0}{5} \\
\frac{0}{\Sigma}\end{array}$} & \multirow{2}{*}{ 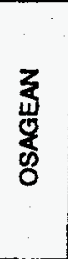 } & $\begin{array}{l}\text { Burlington-Keokuk } \\
\text { Umestone }{ }^{1} \\
\text { (undifiterentiated) }\end{array}$ & $0-185$ & $\begin{array}{l}\text { Umestone; white to bluish- } \\
\text { gray, medium- to coarsely } \\
\text { ctystalline, thickly bedded, } \\
\text { cherty }\end{array}$ & \multirow{2}{*}{ 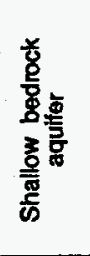 } & \multirow{4}{*}{$\begin{array}{l}\text { Indluidually, the rock units } \\
\text { yield small to moderate } \\
\text { quantities of water to wells } \\
\text { (5-10 gallons per minute). } \\
\text { Collectively, these units } \\
\text { yeld sufficient water to } \\
\text { supply most domestic } \\
\text { and inestock needs }\end{array}$} \\
\hline & & Fern Glen Formation & $0-67$ & $\begin{array}{l}\text { Limestone; yellowish-brown, } \\
\text { fine-grained, medium- to } \\
\text { thickly bedded; contains } \\
\text { appreclable chert }\end{array}$ & & \\
\hline & \multirow{3}{*}{ 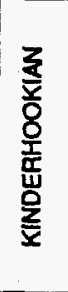 } & $\begin{array}{l}\text { Chouteau Group } \\
\text { (undifferentiated) }\end{array}$ & $0-45(+)$ & $\begin{array}{l}\text { Dolomitic limestone; gray to } \\
\text { yellowish-brown, fine- } \\
\text { grained, thinly to medlum } \\
\text { bedded }\end{array}$ & \multirow{5}{*}{ 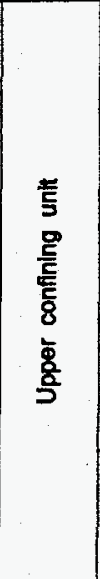 } & \\
\hline & & Bachelor Formation & $0-2$ & Sandstone & & \\
\hline & & Bushberg Sandstone & $0-20$ & $\begin{array}{l}\text { Quartz sandstone; reddish- } \\
\text { brown, fine- to medium } \\
\text { grained, friable }\end{array}$ & & Yields small to moderate \\
\hline 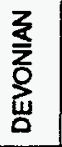 & $\frac{\frac{5}{4}}{\frac{5}{5}}$ & Glen Park Limestone & 0.25 & $\begin{array}{l}\text { Calcareous siltstone and } \\
\text { sandstone with oolitic } \\
\text { limestone with some } \\
\text { dark, hard, cartonaceous } \\
\text { shale }\end{array}$ & & $\begin{array}{l}\text { quantities of water to } \\
\text { wells }(5-50 \text { gallons per } \\
\text { minute })\end{array}$ \\
\hline \multirow{5}{*}{ 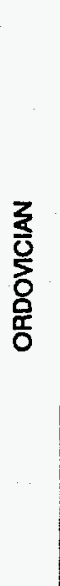 } & 岳 & Maquoketa Shale & $0-11$ & $\begin{array}{l}\text { Calcaroous or dolomitic } \\
\text { shale; typically thinty } \\
\text { laminated, slly wth shaly } \\
\text { limestone lenses }\end{array}$ & & $\begin{array}{l}\text { Yields very small quantities } \\
\text { of water to wells }\end{array}$ \\
\hline & \multirow{4}{*}{$\frac{y}{\frac{0}{2}}$} & KImmswick Limestone & $41-104$ & $\begin{array}{l}\text { Umestore; white to light } \\
\text { gray, coarsely crystalline, } \\
\text { medium- to thicky bedded, } \\
\text { cherty near base }\end{array}$ & 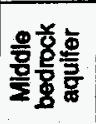 & \multirow{4}{*}{$\begin{array}{l}\text { Yields small to moderate } \\
\text { quantities of water to } \\
\text { wells }(10-50 \text { gallons } \\
\text { per minute) }\end{array}$} \\
\hline & & Decorah Formation & $25-36(+)$ & Thinly bedded limestones & \multirow{3}{*}{ 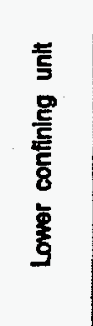 } & \\
\hline & & Piattin Formation & $70-125$ & $\begin{array}{l}\text { Umestone; light to dark } \\
\text { gray, finely crystalline, } \\
\text { thinly bedded, weathers } \\
\text { to pitted surtace }\end{array}$ & & \\
\hline & & Joachim Dolomite & $80-105$ & $\begin{array}{l}\text { Dolostone; yellowish-brown, } \\
\text { slly, thin- to thickty } \\
\text { bedded, grades imto sllt- } \\
\text { stone, shale common }\end{array}$ & & \\
\hline
\end{tabular}

\footnotetext{
${ }^{1}$ Terminology is that of the Missour Division of Geology and Land Survoy.

(D.N. Mugel, U.S. Goological Survey, witten commun., 1996)
}

Flgure 4. Generalized stratigraphic column with descriptions of the lithologic and hydrologic properties of the geologic formations present in southem St. Charles County. 


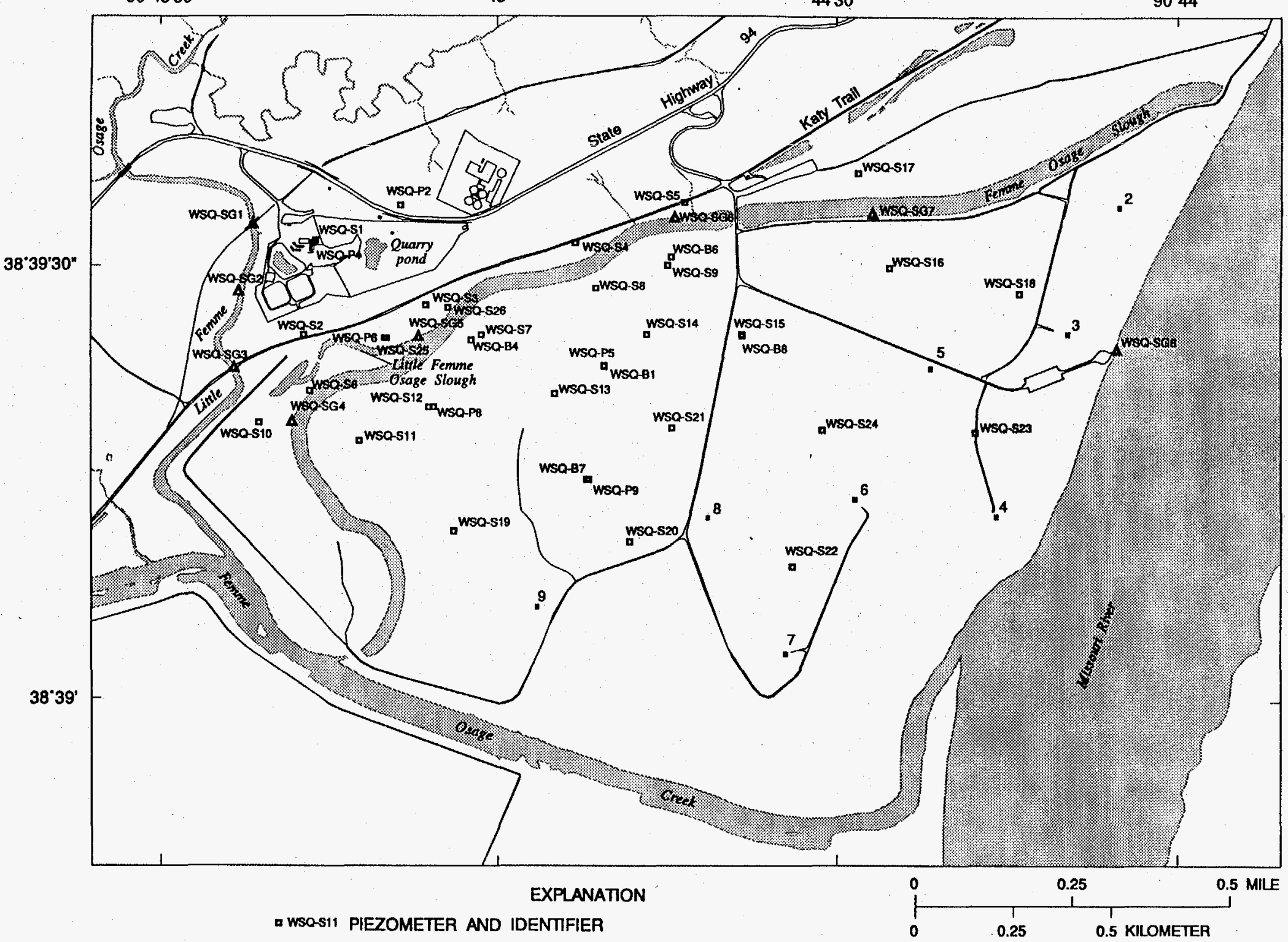

$\triangle$ WSases STAFF GAGE AND IDENTIFIER

.9 WEL IN THE ST. CHARLES COUNTY WEL FIELD AND NUMBER

Fgure 5. Location of piezometers and staff gages installed to monitor water levels. 
Table 1. Site location and construction data for piezometers, monitoring wells, and staff gages in the water-level monitoring network

[ft, feet; --, no data]

\begin{tabular}{|c|c|c|c|c|c|c|c|}
\hline \multirow{2}{*}{$\begin{array}{c}\text { Site } \\
\text { (figs. 5, 6) }\end{array}$} & \multicolumn{2}{|c|}{ State plane zone 4426} & \multirow{2}{*}{$\begin{array}{l}\text { Reference-point } \\
\text { altitude } \\
\text { (ft above sea level) }\end{array}$} & \multirow{2}{*}{$\begin{array}{c}\text { Land-surface } \\
\text { altitude } \\
\text { (ft above sea level) }\end{array}$} & \multirow{2}{*}{$\begin{array}{l}\text { Total depth } 1 \\
\text { (tt below } \\
\text { land surface) }\end{array}$} & \multirow{2}{*}{$\begin{array}{l}\text { Screen interval }{ }^{1} \\
\text { (ft below land } \\
\text { surface) }\end{array}$} & \multirow[b]{2}{*}{ Formation open to plezometer } \\
\hline & $x$-coordinate & y-coordinate & & & & & \\
\hline WSQ-S1 & 747505.750 & 1028858.188 & 487.18 & 483.5 & 40.4 & $30-40$ & Alluvium \\
\hline WSQ-S2 & 747425.900 & 1028190.000 & 469.55 & 465.4 & $14.2(15.5)$ & $(1-.5-15.5)$ & Alluvium \\
\hline WSQ-S3 & 748291.300 & 1028400.000 & 458.82 & 455.1 & $13.1(14.0)$ & $(9.0-14.0)$ & Alluvium \\
\hline WSQ-S4 & 749338.500 & 1028841.000 & 467.72 & 464.0 & $16.0(15.5)$ & $(10.5-15.5)$ & Alluvium \\
\hline WSQ-S5 & 750116.100 & 1029119.000 & 465.91 & 462.5 & $22.0(22.0)$ & $(17.0-22.0)$ & Alluvium \\
\hline WSQ-S6 & 747462.500 & 1027798.000 & 460.59 & 457.3 & 21.5 & $11.5-20.4$ & Alluvium \\
\hline WSQ-S7 & 748685.100 & 1028189.000 & 462.67 & 459.0 & 21.6 & $11.6-20.5$ & Alluvium \\
\hline WSQ-S8 & 749484.600 & 1028524.000 & 463.30 & 459.3 & 21.1 & $11.1-20.0$ & Alluvium \\
\hline WSQ-S9 & 749986.600 & 1028685.000 & 458.74 & 454.8 & 22.1 & $12.0-21.0$ & Alluvium \\
\hline WSQ-S10 & 747108.500 & 1027573.000 & 461.20 & 457.8 & 21.1 & $11.0 \cdot 20.0$ & Alluvium \\
\hline WSQ-S11 & 747820.600 & 1027444.000 & 464.50 & 460.5 & 23.8 & $13.8-22.7$ & Alluvium \\
\hline WSQ-S12 & 748311.400 & 1027682.000 & 463.66 & 459.6 & 21.3 & $11.3-20.2$ & Alluvium \\
\hline WSQ-S13 & 749195.100 & 1027779.000 & 461.83 & 457.8 & 23.9 & $13.9-22.8$ & Alluvium \\
\hline WSQ-S14 & 749839.600 & 1028196.000 & 462.49 & 458.7 & 25.5 & $15.5-24.4$ & Alluvium \\
\hline WSQ-S15 & 750509.300 & 1028195.000 & 461.42 & 457.9 & 25.5 & $25.5 \cdot 24.4$ & Alluvium \\
\hline WSQ-S16 & 751544.900 & 1028662.000 & 462.58 & 458.8 & 21.7 & $11.7-20.6$ & Alluvium \\
\hline WSQ-S17 & 751327.400 & 1029319.000 & 458.59 & 454.8 & 20.8 & $10.8-19.7$ & Alluvium \\
\hline WSQ-S18 & 752455.700 & 1028478.000 & 461.62 & 458.2 & 21.5 & $11.5-20.4$ & Alluvium \\
\hline WSQ-S19 & 748484.500 & 1026814.000 & 465.03 & 461.3 & 22.3 & $12.3-21.2$ & Alluvium \\
\hline WSQ-S20 & 749709.000 & 1026746.000 & 460.61 & 456.9 & 25.2 & $15.2-24.1$ & Alluvium \\
\hline WSQ-S21 & 750009.400 & 1027536.000 & 461.78 & 457.7 & 25.3 & $15.3-24.2$ & Alluvium \\
\hline WSQ-S22 & 750867.900 & 1026570.000 & 464.73 & 460.6 & 23.5 & $13.5-22.4$ & Alluvium \\
\hline WSQ-S23 & 752145.000 & 1027501.000 & 464.36 & 460.3 & 21.4 & $11.4-20.3$ & Alluvium \\
\hline WSQ-S24 & 751072.800 & 1027521.000 & 462.44 & 458.7 & 21.4 & $11.4-20.3$ & Alluvium \\
\hline WSQ-S25 & 748014.000 & 1028166.000 & 459.78 & 457.1 & $23.0(31.0)$ & $(17.0-22.0)$ & Alluvium \\
\hline
\end{tabular}




\begin{tabular}{|c|c|c|c|c|c|c|c|}
\hline \multirow{2}{*}{$\begin{array}{l}\text { Site } \\
\text { (figs. 5, 6) }\end{array}$} & \multicolumn{2}{|c|}{ State plane zone 4426} & \multirow{2}{*}{$\begin{array}{c}\text { Reference-point } \\
\text { altitude } \\
\text { (ft above sea level) }\end{array}$} & \multirow{2}{*}{$\begin{array}{c}\text { Land-surface } \\
\text { altitude } \\
\text { (ft above sea level) }\end{array}$} & \multirow{2}{*}{$\begin{array}{l}\text { Total depth } \\
\text { (ft below } \\
\text { land surface) }\end{array}$} & \multirow{2}{*}{$\begin{array}{c}\text { Screen Interval } \\
\text { (ft below land } \\
\text { surface) }\end{array}$} & \multirow[b]{2}{*}{ Formation open to plezometer } \\
\hline & $x$-coordinate & $y$-coordinate & & & & & \\
\hline WSQ-S26 & 748444.000 & 1028385.000 & 457.63 & 455.0 & $22.9(26.5)$ & $(17.0-22.0)$ & Alluvium \\
\hline WSQ-B1 & 749537.250 & 1027967.313 & 460.65 & 457.0 & 76.0 & $72.0-74.5$ & Base of alluvium \\
\hline WSQ-B4 & 748610.300 & 1028152.000 & 464.17 & 459.4 & $(66.0)$ & $(61.0-66.0)$ & Base of alluvium \\
\hline WSQ-B6 & 750007.100 & 1028739.000 & 460.20 & 455.7 & $(64.0)$ & $(59.0-64.0)$ & Base of alluvium \\
\hline WSQ-B7 & 749431.688 & 1027175.000 & 460.24 & 457.0 & 91.0 & $87.0-89.5$ & Base of alluvium \\
\hline WSQ-B8 & 750508.625 & 1028183.875 & 461.49 & 457.8 & 100.0 & $97.0-99.5$ & Base of alluvium \\
\hline WSQ-P2 & 748106.438 & 1029104.000 & 534.24 & 530.4 & 150 & $139.7-149.7$ & Base of Plattin Formation \\
\hline WSQ-P4 & 747492.000 & 1028846.625 & 487.06 & 483.5 & 147 & $144-146.5$ & Base of Plattin Formation \\
\hline WSQ-P5 & 749542.188 & 1027970.938 & 460.56 & 457.0 & 121.0 & $110-120$ & Base of Plattin Formation \\
\hline WSQ-P6 & 747999.063 & 1028165.875 & 461.49 & 457.4 & 120.5 & $110-120$ & Base of Plattin Formation \\
\hline WSQ-P8 & 748341.313 & 1027683.188 & 463.73 & 460.1 & 120.5 & $110-120$ & Base of Plattin Formation \\
\hline WSQ-P9 & 749418.500 & 1027175.438 & 460.56 & 457.0 & 120.5 & $110-120$ & Base of Plattin Formation \\
\hline MW-1002 & 748499.380 & 1028855.320 & 558.12 & 558.1 & 121.6 & $110.6-115.2$ & Top of Decorah Formation \\
\hline MW-1004 & 748182.200 & 1028603.450 & 538.20 & 537.9 & 100.5 & $86.4-91.0$ & Top of Decorah Formation \\
\hline MW-1006 & 748609.410 & 1028551.530 & 456.49 & 455.0 & 11.1 & $4.5-9.5$ & Alluvium \\
\hline MW-1008 & 748461.930 & 1028486.380 & 456.17 & 454.3 & 10.0 & $5.3-8.2$ & Alluvium \\
\hline MW-1009 & 748497.710 & 1028472.840 & 457.11 & 454.8 & 15.0 & $8.5-12.5$ & Alluvium \\
\hline MW-1010 & 750698.660 & 1028970.620 & 457.24 & 455.8 & 27.5 & $18.4-23.5$ & Alluvium \\
\hline MW-1012 & 748066.810 & 1029087.840 & 532.29 & 531.2 & 91.0 & $79.0-89.0$ & Decorah Formation \\
\hline MW-1014 & 747907.980 & 1028193.190 & 460.37 & 458.2 & 21.3 & $16.0-21.0$ & Alluvium \\
\hline MW-1016 & 748803.420 & 1028633,080 & 462.20 & 460.3 & 15.5 & $10.5 \cdot 15.5$ & Alluvium \\
\hline MW-1019 & 748250.700 & 1027941.740 & 463.90 & 461.2 & 68.0 & $48-68$ & Base of alluvium \\
\hline MW-1021 & 747962.850 & 1027811.200 & 461.01 & 459.0 & 78.3 & $57.5-77.5$ & Base of alluvium \\
\hline MW-1029 & 748573.770 & 1028951.840 & 564.45 & 562.0 & 111.0 & $100.5-110.5$ & $\begin{array}{l}\text { Base of Kimmswick Limestone to } \\
\text { top of Decorah Formation }\end{array}$ \\
\hline MW-1030 & 747759.540 & 1028459.960 & 542.46 & 539.8 & 95.0 & $80.0-90.0$ & $\begin{array}{l}\text { Kimmswick Limestone/Decorah } \\
\text { Formation }\end{array}$ \\
\hline
\end{tabular}


Table 1. Site location and construction data for piezometers, monitoring wells, and staff gages in the water-level monitoring network-Continued

\begin{tabular}{|c|c|c|c|c|c|c|c|}
\hline \multirow{2}{*}{$\begin{array}{c}\text { Site } \\
\text { (figs. } 5,6 \text { ) }\end{array}$} & \multicolumn{2}{|c|}{ State plane zone 4426} & \multirow{2}{*}{$\begin{array}{c}\text { Reference-polnt } \\
\text { altitude } \\
\text { (it above sea level) }\end{array}$} & \multirow{2}{*}{$\begin{array}{c}\text { Land-surface } \\
\text { altitude } \\
\text { (ft above sea level) }\end{array}$} & \multirow{2}{*}{$\begin{array}{l}\text { Total depth } \\
\text { (ft below } \\
\text { land surface) }\end{array}$} & \multirow{2}{*}{$\begin{array}{c}\text { Screen interval }{ }^{1} \\
\text { (ft below land }^{-} \\
\text {surface) }\end{array}$} & \multirow[b]{2}{*}{ Formation open to piezometer } \\
\hline & $x$-coordinate & $y$-coordinate & & & & & \\
\hline MW-1034 & 747851.250 & 1029226.040 & 526.59 & 525.3 & 75.0 & $64.0-74.0$ & $\begin{array}{l}\text { Kimmswick Limeston/Decorah } \\
\text { Formation }\end{array}$ \\
\hline MW-1035 & 747226.40 & 1029259.160 & 478.56 & 476.3 & 30.5 & $20.0-30.0$ & Alluvial aquifer \\
\hline MW-1036 & 747179.480 & 1028754.440 & 479.93 & 480.4 & 41.0 & $29.0-39.0$ & Alluvial aquifer \\
\hline MW-1037 & 747139.490 & 1028452.650 & 479.78 & 480.3 & 41.0 & $29.0-39.0$ & Alluvial aquifer \\
\hline MW-1038 & 747280.420 & 1028394.680 & 479.60 & 480.1 & 36.0 & $24.0-34.0$ & Alluvial aquifer \\
\hline MW-1039 & 747461.230 & 1028452.230 & - & -- & - & -- & -- \\
\hline WSQ-SG1 & 747067.000 & 1028968.000 & -- & -- & - & $\cdots$ & -- \\
\hline WSQ-SG2 & 746969.000 & 1028491.000 & -- & -- & -- & -- & -- \\
\hline WSQ-SG3 & 746932.000 & 1027948.000 & -- & -- & - & -- & -- \\
\hline WSQ-SG4 & 747343.000 & 1027573.000 & -- & -- & - & -- & -- \\
\hline WSQ-SG5 & 748242.000 & 1028167.000 & -- & -- & -- & -- & $\because$ \\
\hline WSQ-SG6 & 750030.000 & 1029011.000 & -- & - & - & - & - \\
\hline WSQ-SG7 & 751424.000 & 1029032.000 & $\cdots$ & -- & - & -- & -- \\
\hline WSQ-SG8 & 753131.000 & 1028067.000 & -- & -- & - & -- & -- \\
\hline
\end{tabular}
1996). 
eter construction design and flooding of the alluvial plain in April 1994 prevented the drilling of shallow alluvial piezometers until late July 1994. A series of administrative delays also kept three of the deep alluvial piezometers (WSQ-B series) and bedrock piezometers (WSQ-S1 and all WSQ-P series) from being drilled until fall 1995, near the completion of the study. Because of this, water-level measurements collected from the designed network needed to be supplemented with water levels measured in existing monitoring wells that were not originally part of the network. All the existing monitoring wells (MW-series wells) that were used are shown in figure 6.

\section{Piezometer and Staff-Gage Network Design}

Piezometers installed in the alluvial aquifer were designed to provide data to enhance the understanding of lateral and vertical ground-water flow in the alluvial aquifer south and southeast of the quarry area. Water-table and potentiometric heads at the base of the alluvial aquifer were monitored using a combination of a primary set of piezometers designed to measure small hydraulic-head differences and a secondary set of piezometers consisting of existing monitoring wells located immediately south of the quarry.

Twenty-five of the primary water-table piezometers (WSQ-S2 to WSQ-S26, fig. 5) were constructed by U.S. Geological Survey personnel specifically for this study to provide a sufficient piezometer spacing and density for monitoring the water-table gradient. The piezometers were drilled with hollow-stem augers and generally ranged from 20.8 to $25.5 \mathrm{ft}$ deep, except piezometers WSQ-S2, WSQ-S3, and WSQ-S4, which were shallower (table 1). These depths were selected so that the piezometer screen would not extend more than about $5 \mathrm{ft}$ below the lowest expected water level. Because augers were used to construct the piezometers and cutting returns were not continuous, lithologic logging at each borehole was not performed.

The piezometer riser pipe and screen consisted of flush-wall, 2-in. (inch) nominal schedule 40 polyvinyl chloride pipe with O-rings inserted at each pipe joint. The slot size used for the screen was 0.010 in. A natural filter pack was used around the piezometer screen to a depth of about $5 \mathrm{ft}$ above the screen. The filter pack was formed by allowing the sands around the auger flights to collapse around the screen as the augers were slowly removed from the hole. When sloughing of the sands would not occur, 30 to 40 mesh, washed sands were added to a depth of about 5 $\mathrm{ft}$ above the screen. The bentonite seal and annular seal were installed by placing 0.375 -in. bentonite chips above the filter pack and hydrating the bentonite in place to the base of the protective casing. Each piezometer was secured with a metal protective casing that extended about $3 \mathrm{ft}$ below land surface.

The shallow water-table piezometers in the alluvial aquifer were developed by using a surge and pump method. The water in the piezometers was initially removed by pumping or bailing until the water from the piezometer was clear. Then, the water in the piezometer was agitated with a surge block, after which the water was again removed. This process of surging and pumping or bailing was repeated three to four times or until surging did not cause the water to become turbid.

Five WSQ-B series piezometers and two existing monitoring wells (MW-1019 and MW-1021 along the southern edge of Femme Osage Slough) were used to collect water-level measurements from the base of the Missouri River alluvial aquifer. The WSQ-B series piezometers also are included with the primary set of piezometers and were paired with other piezometers to measure vertical hydraulic-head differences between selected horizons. Piezometers WSQ-B4 and WSQ-B6 were drilled along the southern edge of Femme Osage Slough and piezometers WSQ-B1, WSQ-B7, and WSQ-B8 were drilled southeast of the quarry, several hundred feet south of the slough (fig. 5). These last three piezometers were not drilled until the fall of 1995. The WSQ-B series piezometers were constructed with either a 2.5 - or 5.0-ft screened interval completed within $10 \mathrm{ft}$ of the base of the alluvial aquifer.

Because small hydraulic-head differences in paired piezometers and a low-angle water-table gradient were expected in the alluvial aquifer, all piezometers that were installed during the study were surveyed to determine a reference-point altitude and location (table 1). The reference point was marked on the top of the casing at each piezometer and all subsequent water-level measurements were made from the indicated point. The reference-point altitudes and locations of existing monitoring wells were available from previous surveys. The reference points were resurveyed near the end of the project to verify the reference altitude had not changed.

Measured water levels in bedrock piezometers and monitoring wells primarily were used to assess patterns of ground-water movement from the quarry 


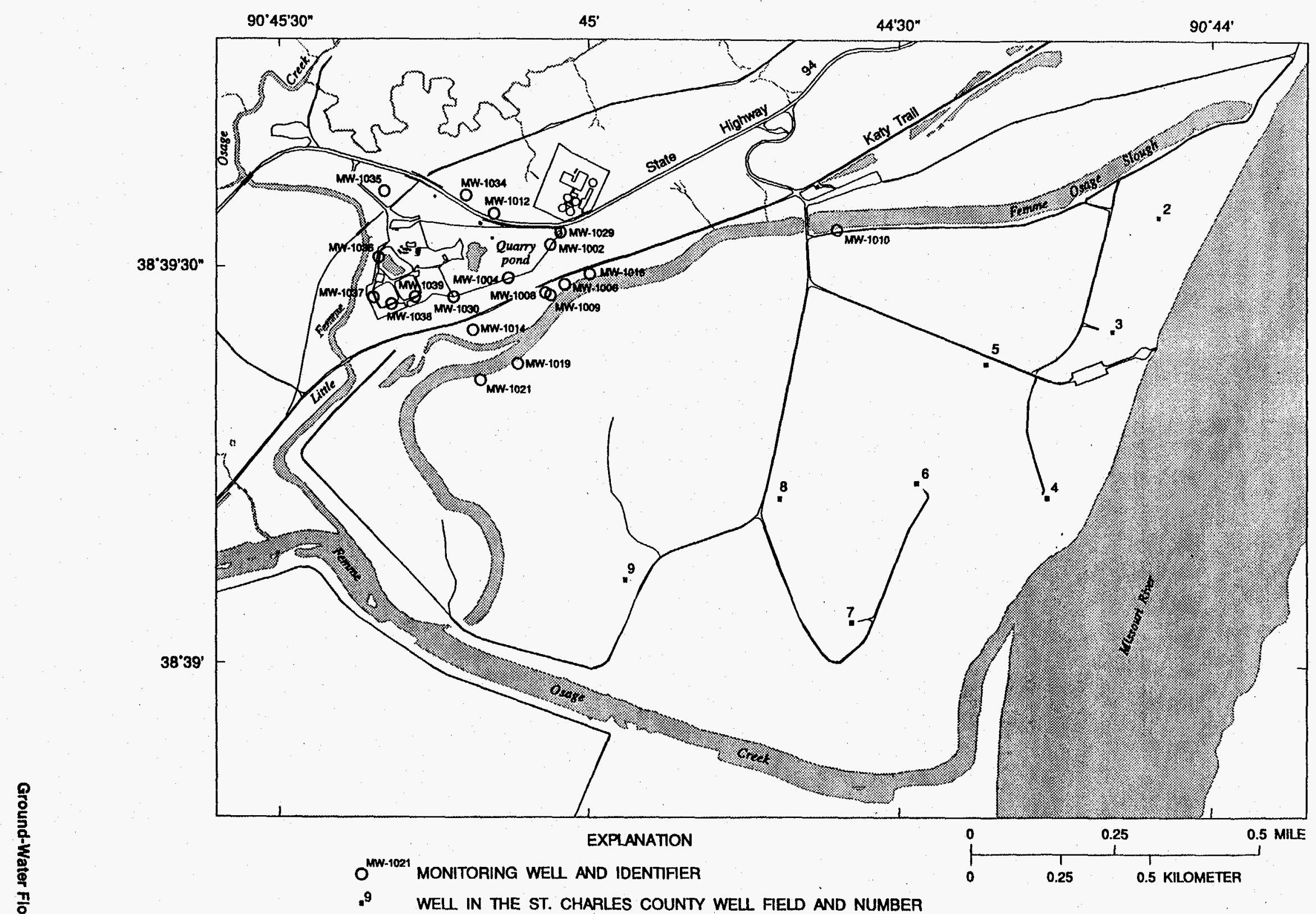

Figure 6. Location of water-quality monitoring wells included in the water-level monitoring network. 
area and the ground-water exchange between the bedrock and the alluvial aquifer. Piezometers in the bedrock near the quarry also were designed specifically to permit the measurement of hydraulic-head differences across the Decorah Formation, which may have a lower permeability than adjacent formations. An attempt to make monthly water-level measurements in the quarry pond was abandoned because of the difficulty of gaining access.

Three piezometers (WSQ-S1, WSQ-P2, and WSQ-P4) were installed near the quarry. Piezometer WSQ-S1 was installed to monitor water leveis near the base of the Little Femme Osage Creek alluvium immediately outside the fenced restricted area at the quarry. The piezometer was located beside a buried bluff at about the same altitude as the base of the Kimmswick Limestone. Piezometers WSQ-P2 and WSQ-P4 were designed so that only a $2.5-$ to $10-\mathrm{ft}$ screened interval (including filter pack) was open to the bedrock. Piezometer WSQ-P2 was drilled $150 \mathrm{ft}$ north of the quarry boundary to monitor water levels in the lower Plattin Formation. Piezometer WSQ-P4 also was completed in the lower Plattin Formation and was paired with piezometer WSQ-S1.

Other becirock piezometers were designed to monitor water levels beneath the Missouri River alluvial aquifer. Bedrock piezometer WSQ-P6 was drilled into the Plattin Formation near the base of the limestone bluff south of the quarry. Three bedrock piezometers (WSQ-P5, WSQ-P8, and WSQ-P9) were drilled through the alluvial aquifer southeast of the quarry and south of Femme Osage Slough to measure water levels in the Plattin Formation.

Piezometer WSQ-S1 and the six WSQ-P series piezometers were not drilled until the fall of 1995. In March 1996 at the completion of the study, the waterlevel in piezometer WSQ-P5 was near a static waterlevel condition and the water level in piezometer WSQ-P8 had attained a static water-level condition. However, water levels in piezometers WSQ-P2, WSQP4, WSQ-P6, and WSQ-P9 were still rising and had not reached static water-level conditions. The low primary permeability of the Plattin Formation was the probable reason why some piezometers did not attain an equilibrium (static water-level) condition before the completion of the study. The piezometers with water levels that stabilized quickly may have penetrated fractures in the bedrock.

Existing water-quality monitoring wells were used to make water-level measurements if the location and construction were sufficient to represent a specific horizon. Sixteen monitoring wells (MW-1002, MW1004, MW-1006, MW-1008, MW-1009, MW-1010, MW-1014, MW-1016, MW-1029, MW-1030, MW1034, MW-1035, MW-1036, MW-1037, MW-1038, and MW-1039) were used to measure the water-table altitude in the bedrock and the alluvium near Little Femme Osage Creek, Little Femme Osage Slough, and Femme Osage Slough. Bedrock water levels in the Decorah Formation were measured in monitoring well MW-1012 (fig. 6).

Eight staff gages were installed on surfacewater bodies (fig. 5) to monitor stage (the height of the water surface of the stream or slough above sea level) and provide data for comparison with ground-water levels near the quarry and in the alluvial aquifer. Staff gages WSQ-SG1, WSQ-SG2, and WSQ-SG3 were installed in Little Femme Osage Creek to help assess. the potential for ground-water discharge from underlying bedrock near the quarry to Little Femme Osage Creek. Staff gages WSQ-SG4, WSQ-SG5, WSQ-SG6, and WSQ-SG7 were installed in Femme Osage Slough to provide data to enhance the understanding of interaction between the slough and the alluvial aquifer. Staff gage WSQ-SG8 was installed on the Missouri River at the Missouri Department of Conservation boat ramp 0.5 river mi downstream from the mouth of Femme Osage Creek. Measurements were read directly from the staff-gage scale and added to the surveyed datum, except for the boat-ramp gage (staff gage WSQ-SG8). The boat-ramp gage was calibrated by surveying the altitude of expansion joints in the concrete ramp and constructing a table for interpolation of stage based on the water-surface distance from a specific expansion joint (table 2).

\section{Ground- and Surface-Water-Level Measurements}

Monthly water-level measurements were made in piezometers, monitoring wells, and at surface-water sites in the study area from August 1994 to February 1996 (table 3, at the back of this report). This period included conditions of low and high river stage, flood stage, and low and high local precipitation. The waterlevel measurements were made from the reference point using an electric tape that was read to the nearest $0.01 \mathrm{ft}$.

Alluvial aquifer water-level measurements scheduled during June 1995 were delayed until early July 1995 because of flooding that occurred when the Missouri River crested levees that protected the St. 
Table 2. Surveyed and interpolated altitudes along the Missouri Department of Conservation boat ramp at the Missouri River [ft, feet; $\cdots$, not applicable; expansion joint numbers increase from the top to the bottom of the boat ramp]

\begin{tabular}{|c|c|c|c|c|c|c|c|c|}
\hline \multirow{2}{*}{$\begin{array}{c}\text { Distance } \\
\text { downramp from } \\
\text { each expansion } \\
\text { joint } \\
\text { (it) }\end{array}$} & \multicolumn{8}{|c|}{$\begin{array}{l}\text { Altitude at specified distance downramp from each expansion joint } \\
\qquad \text { (tt above sea level) }\end{array}$} \\
\hline & $\begin{array}{l}\text { First } \\
\text { joint }\end{array}$ & $\begin{array}{l}\text { Second } \\
\text { joint }\end{array}$ & $\begin{array}{l}\text { Third } \\
\text { joint }\end{array}$ & $\begin{array}{l}\text { Fourth } \\
\text { joint }\end{array}$ & $\begin{array}{l}\text { Fifth } \\
\text { joint }\end{array}$ & $\begin{array}{l}\text { Sixth } \\
\text { joint }\end{array}$ & $\begin{array}{l}\text { Seventh } \\
\text { joint }\end{array}$ & $\begin{array}{c}\text { Eighth } \\
\text { joint }\end{array}$ \\
\hline 0 & 462.33 & 460.87 & 457.96 & 454.83 & 451.81 & 449.36 & 446.03 & 443.70 \\
\hline 1 & 462.24 & 460.73 & 457.80 & 454.68 & 451.65 & 449.20 & 445.88 & 443.55 \\
\hline 2 & 462.15 & 460.59 & 457.64 & 454.52 & 451.49 & 449.05 & 445.72 & 443.40 \\
\hline 3 & 462.06 & 460.45 & 457.48 & 454.36 & 451.33 & 448.90 & 445.57 & 443.25 \\
\hline 4 & 461.97 & 460.31 & 457.32 & 454.21 & 451.18 & 448.75 & 445.42 & 443.10 \\
\hline 5 & 461.88 & 460.17 & 457.16 & 454.05 & 451.02 & 448.60 & 445.27 & 442.96 \\
\hline 6 & 461.79 & 460.03 & 457.00 & 453.90 & 450.87 & 448.45 & 445.12 & 442.81 \\
\hline 7 & 461.70 & 459.89 & 456.84 & 453.74 & 450.71 & 448.30 & 444.96 & 442.66 \\
\hline 8 & 461.61 & 459.75 & 456.68 & 453.59 & 450.55 & 448.15 & 444.82 & - \\
\hline 9 & 461.51 & 459.61 & 456.52 & 453.43 & 450.41 & 448.00 & 444.68 & $\cdots$ \\
\hline 10 & 461.41 & 459.46 & 456.36 & 453.28 & 450.26 & 447.85 & 444.54 & - \\
\hline 11 & 461.31 & 459.31 & 456.21 & 453.15 & 450.11 & 447.70 & 444.40 & -- \\
\hline 12 & 461.21 & 459.16 & 456.06 & 453.01 & 449.96 & 447.55 & 444.26 & -- \\
\hline 13 & 461.11 & 459.01 & 455.90 & 452.86 & 449.81 & 447.40 & 444.12 & -- \\
\hline 14 & 461.01 & 458.86 & 455.74 & 452.71 & 449.67 & 447.26 & 443.98 & -- \\
\hline 15 & 460.91 & 458.70 & 455.59 & 452.57 & 449.52 & 447.11 & 443.84 & -- \\
\hline 16 & -- & 458.55 & 455.44 & 452.42 & - & 446.96 & -- & - \\
\hline 17 & -- & 458.40 & 455.28 & 452.28 & - & 446.81 & - & - \\
\hline 18 & -- & 458.25 & 455.12 & 452.13 & - & 446.66 & - & - \\
\hline 19 & $\cdots$ & 458.10 & 454.97 & 451.98 &.- & 446.52 & -- & - \\
\hline 20 & - & $\ldots$ & $\because$ & -- & -- & 446.37 & -- & -- \\
\hline 21 & -- & -- & - & -- & -- & 446.22 & -- & -- \\
\hline
\end{tabular}


Charles County well field. From October 1995 to February 1996 , the measurement schedule was modified to bi-monthly. Water-table surface maps were constructed for each set of water-level measurements from August-September 1994 to February 1996. Hydraulic-head measurements in deeper strata were not available until October 1995; therefore, potentiometric surface maps for the basal part of the alluvial aquifer were prepared only for December 1995 and February 1996. Potentiometric surface maps for the Plattin Formation were not prepared because of insufficient static water-level data from piezometers completed in the Plattin Formation.

Six piezometers (WSQ-S12, WSQ-S19, WSQ25, WSQ-B4, WSQ-P6, and WSQ-P8), one existing monitoring well (MW-1019), and a stage gage (WSQSG5) on Femme Osage Slough were instrumented with continuous recorders at various times during the study to monitor daily water-table fluctuations (tables $4-9$, at the back of this report). The recorders were used to provide data to compare hydraulic-head changes deeper in the alluvial aquifer and in the Plattin Formation with water-table changes and to compare changes in the surface-water level of Femme Osage Slough with the water table in the alluvial aquifer. The recorders were placed along a general ground-water flow line from the quarry area to the alluvial aquifer. Data collected from the recorders on the piezometers completed in the Plattin Formation (piezometers WSQ-P6 and WSQ-P8) were not used because water levels in these piezometers still had not reached static water-level conditions when data collection ended in February 1996.

\section{Lateral Flow Interpreted from Potentiometric Maps}

The water-table measurements span 19 months and observing the resulting water-table maps in chronological order provides insight about the response of alluvial and bedrock water levels to changing hydrologic conditions that affect hydraulic boundaries. All of the water-table maps display certain similarities. The quarry is located at the west end of a narrow ridge bounded on the south by the Missouri River alluvial valley, on the north by the valley of a tributary creek of Little Femme Osage Creek, and on the west by the Little Femme Osage Creek valley. Lateral groundwater flow (direction of flow lines, fig. 7, at the back of this report) in the bedrock near the quarry as inter- preted from two-dimensional water-table maps can range from southwestward flow toward the Little Femme Osage Creek to southern flow toward the Missouri River alluvium. Apparently, even the more southwestward flowing water turns southward toward the Missouri River alluvium before reaching the Little Femme Osage Creek. The bedrock water-table altitude at monitoring wells MW-1002, MW-1029, and MW1034 near the northern and eastern quarry boundaries varied by $4.11 \mathrm{ft}, 1.99 \mathrm{ft}$, and $4.30 \mathrm{ft}$ throughout the measurement period. In contrast, the water-table altitude in the Little Fermme Osage Creek alluvium west of the quarry as measured in monitoring wells MW$1036, \mathrm{MW}-1037$, and MW-1038 varied by $8.13 \mathrm{ft}$, $10.20 \mathrm{ft}$, and $9.70 \mathrm{ft}$.

Flow in the Missouri River alluvial aquifer south of the quarry generally is southeast to east. Most of the ground water that enters the alluvium from the quarry area flows between areas of higher water-table altitudes near piezometers WSQ-S7 and WSQ-S11 (figs. 5, 7). Under all conditions except after flooding when the water table was unusually high, flow continues eastward toward a typically closed cone of depression near the St. Charles County well field. The position of this depression varies depending on the stage of the Missouri River and the specific wells in the St. Charles County well field that are active at any given time. The variations of water-table altitude in the alluvial aquifer as measured in 25 piezometers (WSQ-S2 to WSQ-S26) and 7 monitoring wells (MW1006, MW-1008, MW-1009, MW-1014, MW-1016, MW-1019, and MW-1021) during the study ranged from 4.15 to $20.76 \mathrm{ft}$. Generally, the range of watertable altitude fluctuations north of the Femme Osage Slough and south of the quarry was less than $11 \mathrm{ft}$. The water-table altitude fluctuations south of the Femme Osage Slough were somewhat greater and ranged from 10.50 to $20.76 \mathrm{ft}$. The measured variation of the Missouri River stage was $19.22 \mathrm{ft}$ during the study. During periods of rising Missouri River stage, the hydraulic gradient in the alluvial aquifer adjacent to the river increases. The gradient increase may indicate that the response of water levels in the aquifer to changes in river stage lag the stage changes because of the presence of fine-grained silt in the alluvium or may indicate that pumped wells in the St. Charles County well field cause water levels in the aquifer adjacent to the river to remain low. Maps showing the water-table altitudes for August-September 1994 to February 
1996 are shown in figures 7 to 22 , at the back of this report.

Water-table altitudes in August-September 1994 (fig. 7) showed that lateral ground-water flow in the quarry area was southwest and south from an area of highest altitude of about $470 \mathrm{ft}$ (monitoring well MW-1029) near the northeastern comer of the quarry perimeter fence. Ground-water flow at the quarry was southwest and became more southerly as it approached the alluvial aquifer. Ground water that flowed southwest beneath the northwestern part of the quarry perimeter fence seemed to discharge along the reach of Little Fernme Osage Creek upstream from the alluvial plain; however, much of the ground water also may flow through permeable alluvial material adjacent to the creek into the alluvial aquifer. Hydraulic gradients in the alluvial aquifer were much smaller than gradients in the bedrock aquifer because of the much larger permeability of the alluvial aquifer. The watertable altitude along the limestone bluff that forms the northern boundary of the alluvial aquifer was about $450 \mathrm{ft}$. South of the quarry, ground water flowed south-southeast away from the bedrock bluff into the alluvial aquifer. Water-table altitudes in piezometers WSQ-S7 (447.59 ft) and WSQ-S11 (450.76ft) were several feet higher than water levels in other nearby piezometers located approximately an equal distance from the bluffs.

Based on ground-water flow directions as interpreted from water-table contours, ground water from the quarry area flowed beneath the bluffs, converged, and flowed between the two piezometers (WSQ-S7 and WSQ-S11). The high water levels in these two piezometers probably were caused by the lenses of viscous blue clay encountered in the upper 15 to $20 \mathrm{ft}$ of these piezometer boreholes during drilling. The large thickness of low-permeability clay at these locations impedes the downward movement of infiltrated precipitation that recharges the alluvial aquifer, causing small mounds of ground water to form. Groundwater flow south of Femme Osage Slough was easterly, toward a ground-water depression in the eastern part of the alluvial aquifer. Femme Osage Creek and the Missouri River were both sources of recharge to the aquifer.

Presumably, the depression occurred because large quantities of ground water were pumped from the base of the alluvial aquifer by high-capacity wells in the St. Charles County well field. The active wells in the St. Charles County well field include wells 2 through 8 (fig. 2); the active wells are rotated monthly (Tom Aaron, Plant Manager, St. Charles County Water Department, oral commun., 1996). The location of the ground-water depression does not coincide with the centroid of these active wells, but was shifted west of the well field away from Femme Osage Creek and the Missouri River. Therefore, the position of this depression may vary depending on the Missouri River stage and probably the number and location of active wells in the St. Charles County well field. Water levels in the Missouri River also were higher than water levels in the alluvial aquifer. A hydraulic-head difference of about $4.47 \mathrm{ft}$ existed between the lowest measured altitude in the depression ( $438.88 \mathrm{ft}$ at piezometer WSQ-S24) and the Missouri River (443.35 ft). This difference indicates that the well field captures large quantities of water from the Missouri River and that less water is captured between the well field and bluff, resulting in the depression shifting toward the bluff and away from the streams.

Water-table altitudes in the quarry area in October 1994 (fig. 8) were quite similar to the water-table altitudes in August-September 1994. The altitude was about $470 \mathrm{ft}$ at the northeast corner of the quarry perimeter fence and about $452 \mathrm{ft}$ near the southwest corner of the perimeter fence (monitoring wells MW1037 and MW-1038; fig. 6). Ground-water flow beneath the quarry was more directly south to the alluvial aquifer than in August-September 1994. The water-table altitude along the limestone bluff that forms the northern boundary of the alluvial aquifer was about $450 \mathrm{ft}$. Ground water beneath the quarry flowed south and entered the alluvial aquifer, then continued flowing south between areas of higher water-table altitudes near piezometers WSQ-S7 $(446.90 \mathrm{ft})$ and WSQ-S11 (450.12 ft), and then flowed eastward. The ground-water depression in the eastern part of the alluvial aquifer is broader and about $1 \mathrm{ft}$ higher than in August-September 1994 and extended northeast beneath the Femme Osage Slough. The Missouri River stage was essentially the same as the stage for August-September 1994, so the hydraulic-head difference between the river ( $443.34 \mathrm{ft}$ ) and the lowest water-table altitude in the depression $(439.53 \mathrm{ft}$ at piezometer WSQ-S24) was $3.81 \mathrm{ft}$.

Water-table altitudes in the quarry area in November 1994 (fig. 9) were 1 to $4 \mathrm{ft}$ higher near the southwestern comer of the quarry area perimeter fence than measured water-table altitudes in the previous 2 months. However, general ground-water flow direc- 
tions remained the same. The water-table altitude remained about $470 \mathrm{ft}$ at the eastern corner of the quarry perimeter fence. Ground-water flow beneath the quarry was south to the alluvial aquifer. Watertable altitudes of 452 to $453 \mathrm{ft}$ along the limestone bluff south of the quarry were slightly higher than they were the previous 2 months. Ground water flowing south beneath the quarry entered the alluvial aquifer and flowed between areas of higher water-table altitude near piezometers WSQ-S7 (455.33 ft) and WSQ$\mathrm{S} 11$ (450.69 ft). The size of the ground-water depression in the eastern part of the alluvial aquifer continued to increase and occupied most of the eastern part of the alluvium. The lowest water-table altitude measured in the depression was $440.27 \mathrm{ft}$ at piezometer WSQ-S24. The depression extended northeast beneath the Femme Osage Slough and beyond the area containing piezometers. The depression was assumed to be closed to the northeast because the Missouri River stage was $449.50 \mathrm{ft}$, about $9 \mathrm{ft}$ above water-table altitudes in the depression.

Water-table altitudes in the quarry area in December 1994 (fig. 10) differed only slightly from those in November 1994. Ground-water flow beneath the quarry was south to the alluvial aquifer. Watertable altitudes along the limestone bluff ranged from about 450 to $452 \mathrm{ft}$. Ground water flowing south beneath the quarry entered the alluvial aquifer and flowed between areas of higher water-table altitudes near piezometers WSQ-S7 (452.04 ft) and WSQ-S11 $(450.36 \mathrm{ft})$, then flowed eastward. Water-table altitudes in much of the alluvial aquifer south of Femme Osage Slough increased slightly from the previous month and the gradients decreased. The location of the ground-water depression in the eastern part of the alluvial aquifer migrated eastward toward piezometer WSQ-S18 from its position the previous month and apparently was open to the Missouri River to the northeast. The Missouri River stage (443.02 ft) declined about $6.5 \mathrm{ft}$ from November 1994 and was only $0.23 \mathrm{ft}$ above the lowest water-table altitude in the ground-water depression.

Water-table altitudes immediately north of the quarry area in January 1995 (fig. 11) were higher than those in December 1994. Near the southwest corner of the perimeter fence water-table altitudes were about 1.5 to $2 \mathrm{ft}$ higher (about 454 to $456 \mathrm{ft}$ ) than they were in December 1994. Ground-water flow beneath the quarry probably was south-southwest toward the alluvial aquifer. Water-table altitudes along the limestone bluff that forms the northern boundary of the alluvial aquifer were about 452 to $455 \mathrm{ft}$. Ground water that entered the alluvial aquifer from beneath the quarry flowed between areas of higher water-table altitude near piezometers WSQ-S7 (458.61 ft) and WSQ-S11 $(456.24 \mathrm{ft})$ and then flowed eastward. The location of the ground-water depression in the eastern part of the alluvial aquifer shifted to the west and was about $1.5 \mathrm{ft}$ lower in altitude than in December 1994. The depression extended an unknown distance northeast beneath Femme Osage Slough. The shift of the depression from its position in December was a result of the higher Missouri River stage in January 1995 (448.63 $\mathrm{ft}$ ) than in December 1994 (443.02 ft). The hydraulichead difference between the river and depression (lowest altitude of $441.22 \mathrm{ft}$ at piezometer WSQ-S16) was about $7.4 \mathrm{ft}$.

Water-table altitudes in the quarry area in February 1995 (fig. 12) were about $471 \mathrm{ft}$ at the northeastern corner of the quarry perimeter fence and about 454 to $456 \mathrm{ft}$ near the southwest corner of the perimeter fence. Ground-water flow beneath the quarry was south-southwest to the alluvial aquifer. Water-table altitudes along the limestone bluff ranged from about $454 \mathrm{ft}$ near the southwest corner of the perimeter fence to about $452 \mathrm{ft}$. Ground water flowing south beneath the quarry entered the alluvial aquifer and flowed between areas of higher water-table altitude near piezometers WSQ-S7 (456.81 ft) and WSQ-S11 (454.88 $\mathrm{ft}$ ), then flowed eastward. The location of the groundwater depression in the eastern part of the alluvial aquifer again shifted eastward toward piezometer WSQ-S18 from its position in January 1995 and was about $2 \mathrm{ft}$ higher (about $443 \mathrm{ft}$ ) than in January 1995. There were insufficient water-level data to confirm the depression closure by onsite measurements; however,

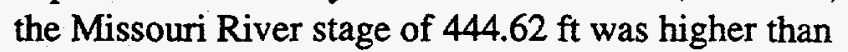
water-level altitudes in the depression. The Missouri River stage was $4.01 \mathrm{ft}$ lower than the stage the previous month.

Water-table altitudes at the eastern edge of the quarry perimeter fence in March 1995 (fig. 13) were slightly higher than they were during the previous month and reflect a small, but continuous trend of increasing hydraulic heads $(1.72 \mathrm{ft}$ increase at monitoring well MW-1029) from October 1994. Watertable altitudes near the southwestern corner of the perimeter fence were about 453 to $456 \mathrm{ft}$, and groundwater flow was southwest beneath the quarry. The water levels increased $1.48 \mathrm{ft}$ at monitoring well $\mathrm{MW}$ - 
1037 and $2.89 \mathrm{ft}$ at monitoring well MW-1038 from levels measured in October 1994. Water-table altitudes along the limestone bluff that forms the northern boundary of the alluvial aquifer were about 452 to 454 ft. Ground water that flowed from beneath the quarry into the alluvial aquifer was directed between the areas of higher water-table altitude near piezometers WSQS7 (456.08 ft) and WSQ-S11 (454.78 ft) and flowed eastward toward the ground-water depression. The depression was much broader than it was the previous month and about $2 \mathrm{ft}$ lower in altitude, despite a $1.37 \mathrm{ft}$ rise in the Missouri River stage to $445.99 \mathrm{ft}$. The hydraulic-head difference between the river and depression (lowest altitude of $441.12 \mathrm{ft}$ at piezometer WSQ-S18) was about $4.9 \mathrm{ft}$.

Water-table altitudes of the quarry area in April 1995 (fig. 14) were slightly lower than they were in March 1995. The altitude was about $471 \mathrm{ft}$ at the northeast corner of the quarry perimeter fence and about 453 and $455 \mathrm{ft}$ near the southwest comer of the perimeter fence. Ground-water flow beneath the quarry was south-southwest to the alluvial aquifer. Water-table altitudes along the limestone bluff ranged from about $453 \mathrm{ft}$ south of the quarry to $451 \mathrm{ft}$ east of the quarry. Ground water flowing south beneath the quarry entered the alluvial aquifer and flowed between areas of higher water-table altitude near piezometers WSQ-S7 (451.88 ft) and WSQ-S11 (453.12 ft) and then flowed eastward. The ground-water depression in the eastern part of the alluvial aquifer was closed, centered about piezometer WSQ-S15 (443.62 ft), and about $2.5 \mathrm{ft}$ higher than it was in March 1995, probably as a result of increased stage in the Missouri River. The depression was located west of its position in March 1995, smaller, and more circular. The Missouri River stage increased to $450.65 \mathrm{ft}$, about $4.7 \mathrm{ft}$ higher than in March 1995. The hydraulic-head difference between the river and depression (lowest altitude of $443.60 \mathrm{ft}$ ) was about $7.0 \mathrm{ft}$.

Water-table altitudes in May 1995 (fig. 15) indicated the first substantial difference from the patterns observed since August-September 1994 and were the first evidence of the effect of the substantial increase in Missouri River stage. Water-table altitudes in the quarry area in May 1995 were about $472 \mathrm{ft}$ at the northeast comer of the quarry perimeter fence and about $\mathbf{4 6 0}$ to $462 \mathrm{ft}$ near the southwest comer of the perimeter fence. Thus, water levels in the unconsolidated sediments along Little Femme Osage Creek were nearly $9 \mathrm{ft}$ higher than levels measured in the previous month. Ground-water flow beneath the quarry was south-southwest to the alluvial aquifer. Water-table altitudes along the limestone bluff boundary of the alluvial aquifer ranged from about 455 to $462 \mathrm{ft}$. Ground water entering the alluvial aquifer from beneath the quarry flowed south near piezometers WSQ-S11 and WSQ-S12 (fig. 5). The areas of higher water-table altitude observed near piezometers WSQS7 and WSQ-S11 in previous months were much more subdued in May 1995. The water-table altitude at piezometer WSQ-S7 (457.64 ft) was about $2 \mathrm{ft}$ higher than it was in wells to the southeast, but the altitude at piezometer WSQ-S11 $(455.66 \mathrm{ft})$ was only a few tenths of a foot higher than it was in wells to the south and west. Ground-water flow, however, probably was similar to that of previous months, eastward toward the depression. The ground-water depression, normally farther east, shifted west in response to the rising Missouri River stage, which was $11.59 \mathrm{ft}$ higher than it was in April 1995. The hydraulic-head difference between the river and depression (lowest altitude of $454.45 \mathrm{ft}$ at piezometer WSQ-S14) was about $7.8 \mathrm{ft}$.

During mid-May 1995, the Missouri River rose above and breached levees designed to protect the well field and alluvial plain from flooding. Floodwaters filled the alluvial plain behind the levees and was trapped in the area for several weeks. The water-level measurements planned for June 1995 were delayed until the first week in July, when a partial set of measurements were made in the bedrock piezometers near the abandoned quarry. Water-table altitudes in the quarry area in early July (fig. 16) were about $472 \mathrm{ft}$ at the northeast corner of the quarry perimeter fence and about 459 to $462 \mathrm{ft}$ near the southwest comer of the perimeter fence. Ground-water flow beneath the quarry was south-southwest into the alluvial aquifer. Water-table altitudes along the limestone bluff were about $463 \mathrm{ft}$ (piezometer WSQ-S2) to $464 \mathrm{ft}$ (piezometer WSQ-S4). Piezometers in the alluvial plain and the Missouri River stage gage were not accessible. The St. Charles County well field remained operational during the flood.

By late July 1995, the Missouri River had receded from flood stage, and a few piezometers in the alluvial plain were again accessible. Water-table altitudes in the quarry area in late July 1995 (fig. 17) were about $471 \mathrm{ft}$ at the northeast comer of the quarry perimeter fence and about 457 to $460 \mathrm{ft}$ near the southwest corner of the perimeter fence. Ground-water flow beneath the quarry may have been south-southwest to 
the alluvial aquifer, as in months before the fiood, or may have become more westerly to discharge into the lower reach of Little Femme Osage Creek. It is difficult to distinguish between the two possibilities because of possible flow path changes resulting from higher water levels in the alluvial aquifer and because of insufficient water-level measurements in the flooded area near the limestone bluff. Water-table altitudes in the alluvial aquifer were highest (about $460 \mathrm{ft}$ ) along the limestone bluff that forms the northern boundary of the aquifer, and altitudes declined steadily to the Missouri River. Ground water that flowed into the alluvial aquifer from the western part of the quarry probably flowed southwest to the Little Femme Osage Creek. Ground water that flowed into the alluvial aquifer from the eastern part of the quarry probably flowed southeast into the Femme Osage Creek or Missouri River. Absent was the ground-water depression in the eastem part of the alluvial aquifer toward which ground water from the quarry flowed in previous months. The Missouri River stage had decreased to $453.72 \mathrm{ft}$ by late July, a decline of $8.52 \mathrm{ft}$ from the stage measured in May 1995.

By August 1995, floodwaters had receded from the alluvial plain, and all piezometers were again accessible. Water-table altitudes in the quarry area in August 1995 (fig. 18) ranged from about $471 \mathrm{ft}$ at the northeast corner of the quarry perimeter fence to about 455 to $457 \mathrm{ft}$ near the southwest comer of the perimeter fence. Ground-water flow beneath the quarry was southwest to the alluvial aquifer. Water-table altitudes along the limestone bluff at the northern boundary of the alluvial aquifer ranged from about 455 to $456 \mathrm{ft}$, and water levels in the alluvial aquifer remained higher than usual because of the flood during May through July. Ground water flowing south beneath the quarry entered the alluvial aquifer and flowed between areas of higher water-table altitude near piezometers WSQ-S7 (457.85 ft) and WSQ-S11 (457.37 ft). After ground water from beneath the quarry flowed between the small ground-water mounds, it probably flowed southeast toward Femme Osage Creek, then flowed east toward the Missouri River. A ground-water depression was beginning to reform in the eastern part of the alluvial aquifer, but had not yet developed to an extent that it strongly affected flow from areas near the quarry. The Missouri River stage was $2.09 \mathrm{ft}$ lower than in the previous month at $451.63 \mathrm{ft}$. The hydraulichead difference between the river and the developing depression (lowest altitude of $449.25 \mathrm{ft}$ at piezometer WSQ-S23) was about $2.4 \mathrm{ft}$.

Water-table altitudes in September 1995 (fig. 19) were similar in the northeast part of the quarry area and about $2 \mathrm{ft}$ lower in the southwestern part of the quarry area as compared to altitudes from August 1995. The altitude was about $471 \mathrm{ft}$ at the northeast corner of the quarry perimeter fence and about 453 to $455 \mathrm{ft}$ near the southwest corner of the perimeter fence. Ground-water flow beneath the quarry was southwest to the alluvial aquifer. Water-table altitudes along the northern boundary of the alluvial aquifer ranged from about 453 to $454 \mathrm{ft}$. Ground water flowing south beneath the quarry entered the alluvial aquifer and flowed between areas of higher water table altitude near piezometers WSQ-S7 (453.63 ft) and WSQ-S11 (454.08 ft) and then eastward toward the ground-water depression. The depression in the eastern part of the alluvial aquifer was larger and centered west of the depression observed redeveloping in August 1995. The Missouri River stage (447.69 ft) declined about $4 \mathrm{ft}$ from the August 1995 measurement, and the hydraulic-head difference between the river and depression (lowest measured altitude of $443.85 \mathrm{ft}$ at piezometer WSQ-S24) was about $3.8 \mathrm{ft}$.

Water-table altitudes in the quarry area in October 1995 (fig. 20) ranged from about $470 \mathrm{ft}$ at the northeast corner of the quarry perimeter fence to about $452 \mathrm{ft}$ near the southwest corner of the perimeter fence. Ground-water flow beneath the quarry was south-southeast to the alluvial aquifer, then eastward to the closed ground-water depression. Water-table altitudes along the limestone bluff that forms the northern boundary of the alluvial aquifer ranged from about 452 to $453 \mathrm{ft}$. Ground water flowing south beneath the quarry entered the alluvial aquifer and flowed between areas of higher water-table altitude near piezometers WSQ-S7 (450.06 ft) and WSQ-S11 $(452.17 \mathrm{ft})$. The ground-water depression in the eastern part of the alluvial aquifer was much broader and centered farther west than it was in September 1995; however, water-table altitudes in the depression remained about the same as in September 1995. The Missouri River stage remained almost unchanged from September 1995 (447.48 ft) and, therefore, the hydraulic-head difference between the river and depression (lowest measured altitude of $443.39 \mathrm{ft}$ at piezometer WSQ-S24) remained about $4.1 \mathrm{ft}$.

Water-table altitudes in the quarry area in December 1995 (fig. 21) differed little from October 
1995. The altitude was about $470 \mathrm{ft}$ at the northeast corner of the quarry perimeter fence and declined to about $453 \mathrm{ft}$ near the southwest corner of the perimeter fence. Ground-water flow beneath the quarry remained south-southwest to the alluvial aquifer. Water-table altitudes along the northern boundary of the alluvial aquifer ranged from about 451 to $453 \mathrm{ft}$. Ground water flowed south beneath the quarry and entered the alluvial aquifer. Flow continued between areas of higher water-table altitude near piezometers WSQ-S7 $(448.61 \mathrm{ft})$ and WSQ-S11 (450.97 ft) and then eastsoutheast toward the presumably closed ground-water depression. The center of the depression shifted to the south from its position in October 1995 and was about $0.4 \mathrm{ft}$ lower. The Missouri River stage declined $0.76 \mathrm{ft}$ from October 1995 to $446.72 \mathrm{ft}$. The hydraulic-head difference between the river and depression (lowest altitude of $442.95 \mathrm{ft}$ at piezometer WSQ-S22) was about $3.8 \mathrm{ft}$.

Water-table altitudes in the quarry area in February 1996 (fig. 22) were about $470 \mathrm{ft}$ at the northeast comer of the quarry perimeter fence and about 453 to $455 \mathrm{ft}$ near the southwest corner of the perimeter fence. Ground-water flow beneath the quarry was southwest to the alluvial aquifer. The water-table altitudes along the limestone bluff that forms the northern boundary of the alluvial aquifer were about 450 to 452 $\mathrm{ft}$. Ground water beneath the quarry flowed southwest, then south to the alluvial aquifer. After entering the alluvial aquifer, the ground water continued flowing southeast between areas of higher water-table altitudes near piezometers WSQ-S7 (449.54 ft) and WSQ-S11 $(451.88 \mathrm{ft})$, and then flowed eastward. The presumably closed ground-water depression in the eastern part of the alluvial aquifer was broader and about $0.5 \mathrm{mi}$ northeast of its position in December 1995. The depression extended northeast beneath the Femme Osage Slough. The Missouri River stage was 445.31 $\mathrm{ft}$, or $1.41 \mathrm{ft}$ lower than the stage in December 1995. The hydraulic-head difference between the river and the depression (lowest altitude of $440.48 \mathrm{ft}$ at piezometer WSQ-S16) was about $5 \mathrm{ft}$.

During the fall of 1995, a sufficient number of the piezometers originally proposed to monitor ground-water levels in the more permeable coarsegrained basal part of the alluvial aquifer were completed in the northern part of the alluvial aquifer to permit mapping of the potentiometric surface in that area. However, there were no data collected in the southern or the eastern part of the alluvial aquifer near the St. Charles County well field or the Missouri River. The potentiometric surface (fig. 23) in December 1995 showed water-level altitudes decreased to the south and east toward the well field. The lowest waterlevel altitude was measured in piezometer WSQ-B7 (443.44 ft), which was located north and west of the well field. The potentiometric surface altitude in this piezometer was about $3 \mathrm{ft}$ lower than the Missouri River stage $(446.72 \mathrm{ft})$. In the northern part of the alluvial aquifer, south of the quarry, the altitude of the December 1995 water table (fig. 21) was several feet higher than the potentiometric surface measured in the coarse-grained basal part of the alluvial aquifer. To the south and east, the water table and potentiometric surface at the base of the aquifer began to converge. The reason for this convergence is not readily apparent, but indicates a complex flow pattern within the alluvial aquifer. A more complete understanding of the flow system may not be possible without the benefit of a three-dimensional ground-water flow simulation that includes the detailed effects of ground-water withdrawals by the St. Charles County well field.

A comparison of the potentiometric surface altitude of the basal part of the alluvial aquifer (fig. 24) and the water-table altitude measured in February 1996 shows the same general trend as the December 1995 measurements. However, in February 1996 a vague expression of the possible development of a ground-water depression in the basal part of the alluvial aquifer is shown. This possible depression is elongated along an east-west trend with the axis being less than $0.25 \mathrm{mi}$ south of the Femme Osage Slough. The lowest water-level altitude measured in this possible depression was about $4 \mathrm{ft}$ lower than the Missouri River stage ( $445.31 \mathrm{ft}$ ), and the depression is located about $0.25 \mathrm{mi}$ west of the mapped water-table depression (fig. 22). However, these two depressions may coincide.

\section{Flow Interpreted from Hydraulic-Head Differences along Two Sections}

Two-dimensional water-table maps provide insight into the flow of ground water, but are not adequate to show the three-dimensional characteristics of a complex flow system. Water-level measurements were also made in deep piezometers to help assess vertical ground-water flow patterns. Vertical hydraulichead differences along two flow paths extending from 


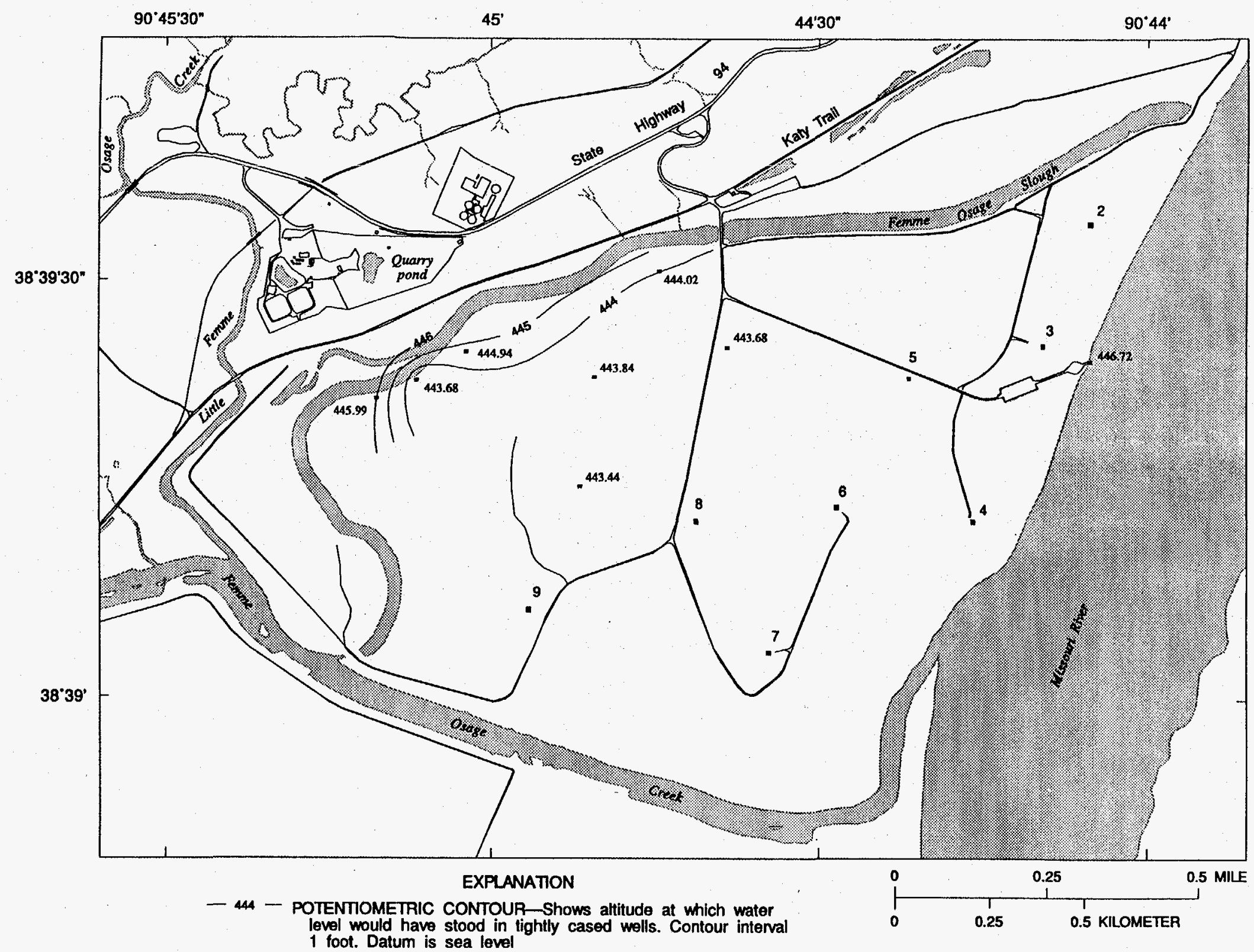

.443.44 CONTROL POINT-Number is water-level altifude, in feet

. WELL IN THE ST. CHARLES COUNTY WELL FIELD AND NUMBER

Fgure 23. Potentiometric surface of the coarse-grained basal part of the alluvial aquifer, December 1995. 


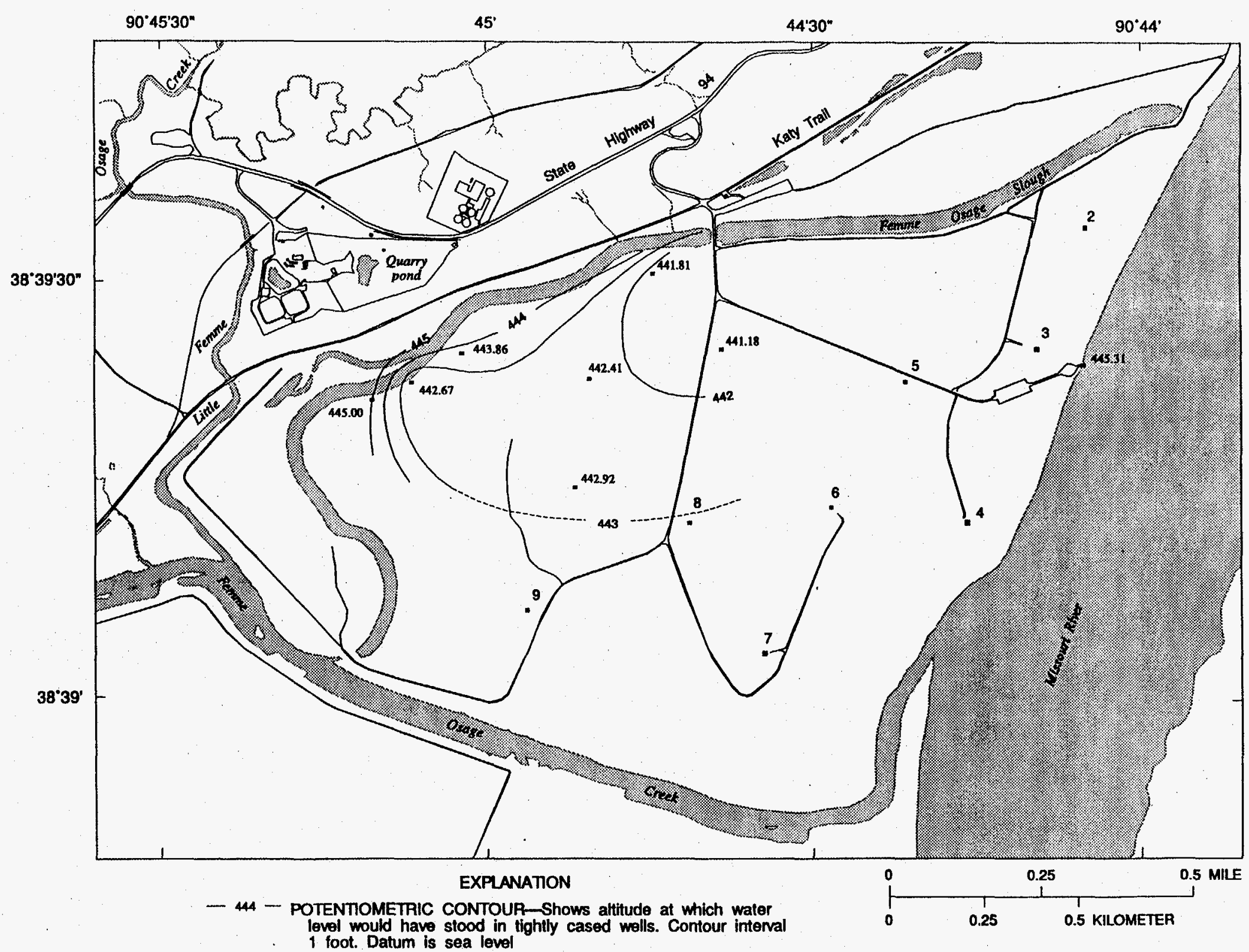

.42.92 CONTROL POINT-Number is water-tevel altitude, in feet

9 WELL IN THE ST. CHARLES COUNTY WELL FIEL AND NUMBER

Fgure 24. Potentiometric surface of the coarse-grained basal part of the alluvial aquifer, February 1996. 
the upland bedrock aquifer into the Missouri River alluvial aquifer are shown in figures 25 and 26 . The westernmost section (fig. 25) begins north of the quarry area and ends at the ground-water depression east of the quarry; however, three piezometers completed in the Plattin Formation along this cross section were drilled too late in the study for ground-water levels in the piezorneters to achieve static water-level conditions before the final measurements were taken in February 1996. However, the available data are sufficient to indicate the ground-water flow pattern depicted by potentiometric contours in figure 25 . The easternmost section (fig. 26) extends along a flow path from the upland area north of the alluvial aquifer southeast to the ground-water depression. No piezometers completed in the Plattin Formation were drilled along this flow path.

Ground water flowing from the quarry can flow either preferentially along bedding planes at the top of the Decorah Formation to the shallow sediments of the alluvium or move downward through the Decorah Formation and underlying Plattin Formation to discharge into the base of the alluvial aquifer (fig. 25). Either situation or a combination of both is possible depending on the integrity of the confining material in the Decorah Formation, hydraulic heads near the quarry, and the water level in the quarry pond. Ground water that flows from the quarry along the bedding plane associated with the Kimmswick Limestone-Decorah Formation contact probably moves into unsaturated sediment in the alluvial aquifer a few feet beneath the limestone bluff at the north edge of the alluvium. After entering the alluvium, the water percolates downward to the water table.

Regional ground water that flows beneath the quarry travels downward into the Plattin Formation and laterally toward the base of the alluvial aquifer where it is discharged. The direction of flow is perpendicular to potentiometric contour lines shown in figure 25. Water levels measured in piezometers in February 1996 indicate that ground water moves downward from the water table and laterally downgradient (figs. $22,25)$. Flow from the water table converges with flow from the Plattin Formation in the highly permeable gravel and sand at the base of the alluvial aquifer. The downward hydraulic gradient shown at monitoring well MW-1019 in figure 25 is the gradient from the water table to the well screen at the base of the alluvial aquifer. The water-table altitude used in the calculation for monitoring well MW-1019 was interpolated from the water-table contours shown on figure 22 at the location of monitoring well MW-1019. The upward gradient shown at piezometer WSQ-P8 is the gradient between the screened intervals in piezometer WSQ-P8 in the Plattin Formation and monitoring well $M W-1019$. The movement of ground water into the more permeable coarse-grained material at the alluvial aquifer base is indicated by these gradients. The downward gradient shown at piezometer WSQ-B8 probably is smaller than the error associated with the ground-water level estimates and measurements used in the gradient calculation. Thus, the vertical gradient in this part of the aquifer probably is near zero, and its direction cannot be determined with certainty using the available data.

Ground-water flow parallel to the cross section depicted in figure 26 also is from the upland bedrock area into the alluvial aquifer. Although ground-waterlevel measurements are not available in the Plattin Formation along this flow path, ground water probably flows from the upland area into the alluvial aquifer along a similar flow pattern as observed along trace $A-A^{\prime}$. The two vertical hydraulic gradients associated with piezometers WSQ-B6 (0.002 upward gradient) and WSQ-B8 (0.001 downward gradient) are estimated gradients from the water table to the base of the alluvial aquifer. Both calculated values probably are smaller than the uncertainty inherent in the calculations; therefore, the actual gradients probably are near zero, and their directions cannot be determined with certainty.

\section{GROUND- AND SURFACE-WATER INTERACTION}

The proximity of Femme Osage Slough and perennial Little Femme Osage Creek to the Weldon Spring quarry indicates that these surface-water bodies may either supply water to or remove water from the ground-water system near the quarry. The ground- and surface-water interaction was assessed by monitoring the stages of Femme Osage Slough and Little Femme Osage Creek at several locations and comparing the stage with nearby ground-water levels. Also, three seepage runs, which consist of a series of discharge measurements made in a short time along a stream reach, were conducted on the downstream reaches of Little Femme Osage Creek. The seepage runs were conducted in an attempt to identify where gains or 


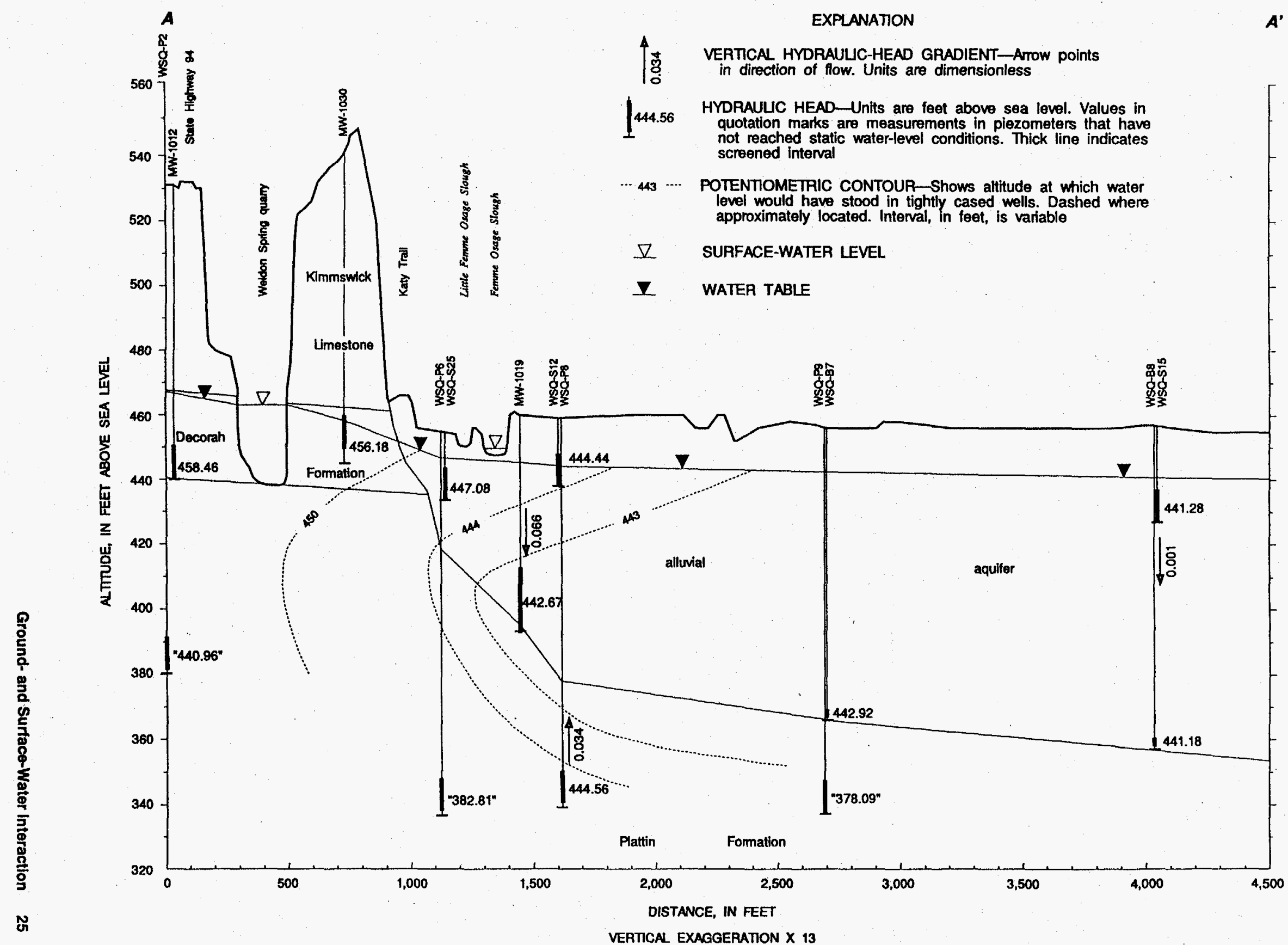

Figure 25. Vertical hydraulic-head differences along cross section A-A' from the Weldon Spring quarry to the Missour River alluvial aquifer, February 1996 (location of section is shown in figure 22). 


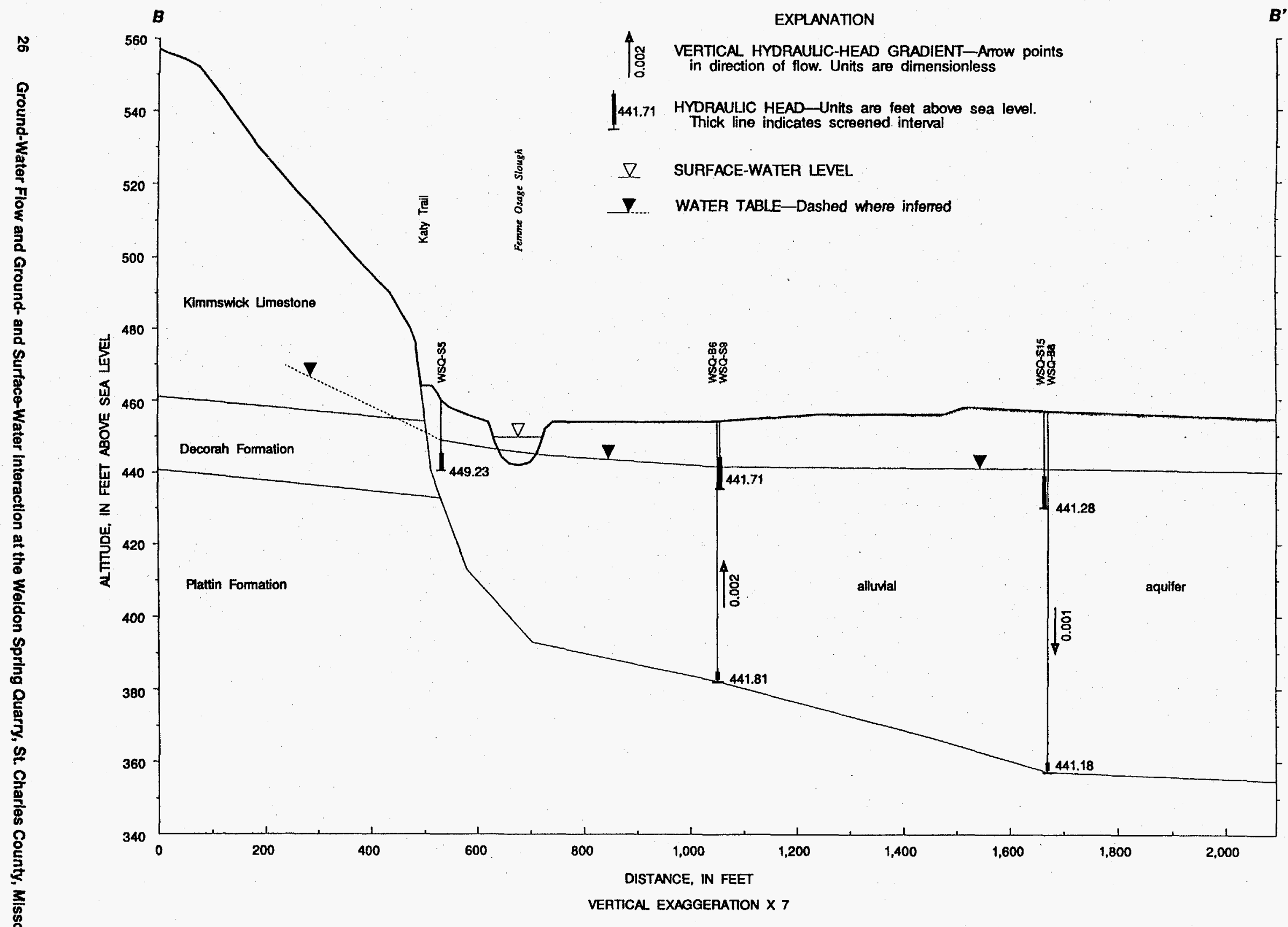

Fgure 26. Vertical hydraulic-head differences along cross section $B-B^{\prime}$ from the upland area northeast of the Weldon Spring quarry to the Missour River alluvial aquifer, February 1996 (location of section is shown in figure 22). 
losses in streamflow occur and to complement the stage and ground-water level data.

\section{Recharge of the Alluvial Aquifer by Femme Osage Slough}

Water-level recorders were installed on selected piezometers during the study to monitor daily fluctuations in ground-water levels and provide data for accurate correlations of water levels between paired wells installed to different depths. Mean daily water-level altitudes in these piezometers and the mean daily stage of Femme Osage Slough (staff gage WSQ-SG5) are listed in tables 4 through 9 . Four recorders were installed on or near Femme Osage Slough south of the quarry to assess the interaction between surface water in the slough and water-table altitudes in the alluvial aquifer and to assess vertical water movement in the alluvial aquifer beneath the slough. These recorders were placed at piezometer WSQ-S12 (a water-table piezometer completed in alluvial clay approximately $330 \mathrm{ft}$ south of the slough), piezometer WSQ-S25 (approximately $80 \mathrm{ft}$ north of the slough), monitoring well MW-1019 (completed in the base of the alluvial aquifer approximately $40 \mathrm{ft}$ south of the slough), and Femme Osage Slough (staff gage WSQ-SG5). Hydrographs for these sites are shown in figure 27 from October 1994 to February 1996. The precipitation data shown in figure 27 are from a U.S. Department of Energy rain gage installed at the quarry.

At all times during the study, except under flood conditions, water levels in Femme Osage Slough were higher than the water table in the aquifer beneath the slough. Ground-water flow was, therefore, downward from the slough to the aquifer. However, because there was no evidence of ground-water mounding beneath or adjacent to the slough, the rate of downward flow beneath the slough is assumed to be small.

From January to mid-April 1995, water-table altitudes north of the slough (piezometer WSQ-S25) averaged about $2.5 \mathrm{ft}$ higher than those south of the slough (piezometer WSQ-S12), indicating a southward gradient beneath the slough. Water levels in these two piezometers respond similarly to precipitation. Water levels in monitoring well MW-1019 were consistently lower than the water table by about $1 \mathrm{ft}$. Thus, vertical water movement in the alluvial aquifer in this area was downward to the more permeable coarse-grained material at the base of the aquifer. Water-level fluctuations at the base of the alluvial aquifer were subdued as com- pared to fluctuations at the water table. The stage of the Femme Osage Slough (staff gage WSQ-SG5) was higher than alluvial water levels north and south of the slough, indicating the slough was a source of recharge to the ground-water system.

From mid-April to mid-September 1995, water levels at the four recorder sites changed substantially as the Missouri River crested during a major flood and then receded. The levees constructed around the well field failed to keep floodwaters out of the alluvial plain. As water levels in the Missouri River rose toward flood stage, water levels in the alluvial aquifer and slough also rose, and differences between water levels in the piezometers and surface water in the slough became smaller. By mid-May, the water-table altitude was about $455 \mathrm{ft}$. Within a few days after this short period of coalescing water-table altitudes, ground-water levels in piezometer WSQ-S12 and monitoring well MW-1019 were higher than the surface-water level in the slough by about $1.5 \mathrm{ft}$, and water from piezometers and wells completed in the lower part of the alluvial aquifer began to flow.

Immediately before the levee breach by floodwaters, all of the installed recorders were removed. The recorders were re-installed in piezometers after the floodwaters receded and the piezometer casings were again exposed. Data were not collected from any piezometer from mid-May to mid-July. The recorder at Femme Osage Slough could not be reinstalled until September 1995.

Water levels in alluvial piezometers were still declining 3 months after floodwaters had receded. The water levels in piezometer WSQ-S25 (north of the slough) typically were higher than water levels in piezometer WSQ-S12 (south of the slough) between midJuly and late September. This difference in water-table altitudes steadily increased from less than $1 \mathrm{ft}$ in late July to about $2.5 \mathrm{ft}$ in late September, except for a few days in early August. Water-table altitudes in piezometer WSQ-S12 were greater than water levels at the base of the aquifer in monitoring well MW-1019 (south of the slough). The hydraulic-head difference between these piezometers remained fairly steady at about $0.5 \mathrm{ft}$ except for a few days in early August when all levels sharply increased. The stage in Femme Osage Slough was consistently at least $2 \mathrm{ft}$ higher than the water table in the alluvial aquifer through September 1995.

From October 1995 to February 1996, recorded water levels were similar to those measured during preflood conditions. However, the data indicate ground- 


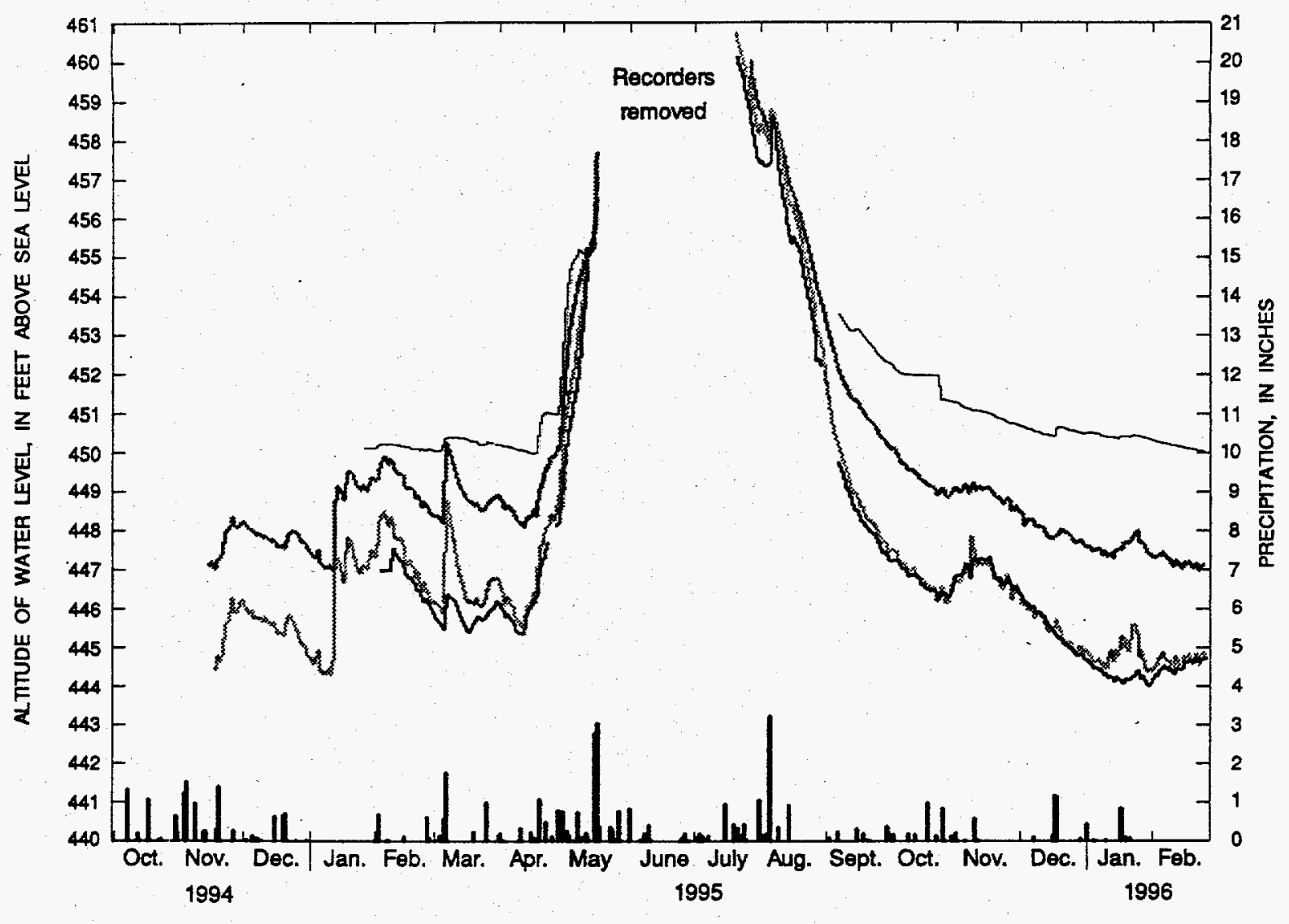

EXPLANATION

WATER-LEVEL ALTTUDE IN PIEZOMETER WSQ-S12
WATER-LEVEL ALTITUDE IN PIEZOMETER WSQ-S25
WATER-LEVEL ALTITUDE IN MONITORING WEU MW-1019
FEMME OSAGE SLOUGH STAGE AT STAFF GAGE WSQ-SG5
DAILY PRECIPTATION

Figure 27. Daily mean water-level altitudes in. piezometers WSQ-S12 and WSQ-S25 and monitoring well MW-1019 and at gage WSG-SG5 (Femme Osage Slough).

water levels in the piezometers in the alluvial aquifer continued to slowly recede throughout most of the fall and early winter after the flooding earlier in the summer. The water table north of the slough (piezometer WSQS25) again averaged about $2.5 \mathrm{ft}$ higher than that immediately south of the slough (piezometer WSQ-S12), indicating ground-water flow was to the south beneath the slough. Water levels in the three recording piezome- ters in the alluvial aquifer were below surface-water levels in the slough, indicating the ground-water system was being recharged by the slough. Water levels at the base of the aquifer (monitoring well MW-1019) in the vicinity of the slough were slightly lower than the water table in the alluvial aquifer, indicating that ground water had resumed moving downward into the more permeable material. 


\section{Ground-Water Discharge to Little Femme Osage Creek}

Three seepage-run measurements were made on Little Femme Osage Creek near the quarry between August 24, 1994, and October 26, 1995. The stream discharge was measured with a current meter using the general methods adopted by the U.S. Geological Survey (Carter and Davidian, 1968). The discharge measurements were made to determine if the creek gained or lost flow to the ground-water system in the area of the quarry and to determine if seasonal changes affected recharge/discharge patterns between the creek and the ground-water system. Specific conductance and water temperature were determined at most measuring locations. Specific conductance values were measured using a portable conductivity meter with temperature compensation designed to express readings in microsiemens per centimeter at 25 degrees Celsius. Water temperature was measured using the thermistor of the conductivity meter.

The first seepage run was conducted on August 24,1994 , during a period of low flow. This seepage run was more extensive than the two subsequent seepage runs and included the stream reach from 3.25 river $\mathrm{mi}$ upstream from the mouth of Little Femme Osage Creek to the mouth of the creek. Dry stream reaches with scattered pools of water were encountered in the upstreammost reaches. Streamflow was not observed in the creek until flow from a spring entered the creek about 1.9 river mi upstream from the mouth (site 3; table 10). Water continued to flow in the creek for the next 0.25 river mi until a large gravel bar that spanned the creek was encountered, and all visible flow was lost (site 6). Water from the creek was not likely lost to the aquifer at this point, but was flowing through the streambed gravel. About $200 \mathrm{ft}$ downstream from site 6 , the streamflow re-emerged in the creek (site 7). The visible quantity of flow in the creek continued to fluctuate downstream (sites 8-10); this fluctuation is thought to be caused by the sometimes large, mounded gravel bars located in the creek. Downstream from site 11 (fig. 28), the large gravel bars were not present, and conditions for making discharge measurements and observations improved. Flow in the creek generally increased from site 12 to site 17 ; however, much of this flow was caused by the infiow of tributary streams. Flow was shown to decrease by $0.032 \mathrm{ft}^{3} / \mathrm{s}$ (cubic foot per second) between site 17 and 18 , but the specific conductance of the water did not substantially change.
The second seepage run was conducted on March 17,1995 , during a period of high flow. This seepage run included the reach 1 river mi upstream from the mouth of Little Femme Osage Creek to the mouth of the creek (fig. 29). The scope of the seepage run was decreased because of the large gravel bars upstream from site 10 (fig. 28) that affected flow conditions. During this seepage run, the creek had more flow than during the first seepage run, but the results were similar (table 10). Flow continued to increase downstream, but this increase was caused by inflow from tributary streams. The slight fluctuation in flow between sites 4 and 6 is within the 5 percent accuracy of current meter discharge measurements rated "good," and the specific conductance of the water did not substantially change.

The third seepage run was conducted on October 26,1995 , during a period of low flow. This seepage run included the reach 1.5 river mi upstream from the mouth of Little Femme Osage Creek to the mouth of the creek (fig. 30). Flow in the stream channel was obstructed by leaves throughout most of this stream reach. Again, flow in the creek increased downstream because of inflow from tributary streams. The increase in flow between sites 4 and 6 could not be completely accounted for by the surface-water inflow measured at site 5. A direct correlation exists between specific conductance and dissolved solids concentrations (Hem, 1985). The product of multiplying the discharge and the specific conductance value measured at each site is an estimate of the dissolved solids load at each site. Comparing these products at sites $4,5,6$, and 7 indicates the discharge at site 5 may have been under-measured by about $0.03 \mathrm{ft}^{3} / \mathrm{s}$. Because of the low flows occurring during this seepage run, small variations in measured flow produce substantial differences (more than 5 percent) when comparing discharges. Some of these discharge fluctuations may be attributed to inherent imprecision of current-meter discharge measurements caused by variations in flow conditions at the various measuring cross sections.

Based on the three seepage runs, gains or losses of streamflow in Little Femme Osage Creek near the quarry are minimal, and, therefore, little exchange of water occurs between the underlying bedrock and Little Femme Osage Creek. Fluctuations in discharge measured during the low-flow seepage runs seem significant when comparing percent differences between sites; however, the quantity of flow involved in creating these differences is small. 
Table 10. Stream-discharge measurements on Little Femme Osage Creek (August 24, 1994, March 17, 1995, and October 26, 1995)

$\left[\mathrm{ft}^{3} / \mathrm{s}\right.$, cubic feet per second; $\mu \mathrm{S} / \mathrm{cm}$, microsiemens per centimeter at 25 degrees Celsius; ${ }^{\circ} \mathrm{C}$, degrees Celsius;,-- no data; e, estimated]

\begin{tabular}{|c|c|c|c|c|c|}
\hline $\begin{array}{l}\text { Measurement } \\
\text { number }\end{array}$ & Stream & $\begin{array}{c}\text { Discharge } \\
\left(f t^{3} / s\right)\end{array}$ & $\begin{array}{c}\text { Specific } \\
\text { conductance } \\
(u S / \mathrm{cm})\end{array}$ & $\begin{array}{l}\text { Temperature } \\
\left({ }^{\circ} \mathrm{C}\right)\end{array}$ & Remarks \\
\hline
\end{tabular}

Little Femme Osage Creek

2 Little Femme Osage Creek

3 Little Femme Osage Creek Tributary

$4 \quad$ Little Femme Osage Creek

$5 \quad$ Little Femme Osage Creek

6 Little Femme Osage Creek

$7 \quad$ Little Femme Osage Creek

8. Little Femme Osage Creek

9 Little Femme Osage Creek

10 Little Femme Osage Creek

11 Little Femme Osage Creek Tributary

12

13

Little Femme Osage Creek

Little Femme Osage Creek Tributary

Little Femme Osage Creek Tributary

Little Femme Osage Creek

Little Femme Osage Creek

Little Femme Osage Creek
Angust 24, 1994 (fig. 28)

$\begin{array}{cccl}0.0 & -- & - & \text { No flow } \\ .0 & 425 & 20.1 & \text { No flow; scattered pools } \\ .03 & 425 & 20.3 & \text { Left bank; flow begins; enters pool } \\ .02 & - & -- & \text { Flow out of pool } \\ .10 & 450 & 20.5 & \\ - & -- & -- & \text { No flow observable; large gravel bar } \\ - & - & -- & \text { Flow returning } \\ .03 \mathrm{e} & -- & -- & \text { Large pool; gravel; decreased flow } \\ - & -- & -- & \text { Small flow in gravel bar } \\ .06 & 437 & 21.0 & \\ .02 \mathrm{e} & -- & -- & \text { Left bank; no observable flow at mouth; } \\ & & & \text { gravel bar }\end{array}$

22.0

.. Left bank; no flow

21.4

24.4

23.7

23.1

26.5

-. Water pooled at mouth of stream

March 17, 1995 (fig. 29)

$\begin{array}{rrrl}2.88 & 381 & 14.4 & \\ 1.18 & 447 & 15.6 & \text { Left bank } \\ .64 & 553 & 15.1 & \text { Right bank; State Highway 94 bridge } \\ 4.65 & 428 & 14.7 & \text { Upstream of quarry } \\ 4.56 & 433 & 14.6 & \text { Katy Trail Bridge } \\ 4.68 & 438 & 14.3 & \text { Near mouth }\end{array}$

October 26, 1995 (fig. 30)

\begin{tabular}{|c|c|c|c|}
\hline 0.09 & 389 & 12.2 & \\
\hline .20 & 417 & 12.2 & Across from old quarry entrance \\
\hline .03 & 578 & 10.9 & Left bank \\
\hline .23 & 435 & 10.8 & $\begin{array}{l}400 \text { feet upstream from State Highway } 94 \\
\text { bridge }\end{array}$ \\
\hline .08 & 800 & 12.5 & Right bank \\
\hline .36 & 540 & 11.5 & 60 feet downstream from walkway bridge \\
\hline .33 & 557 & 11.4 & $\begin{array}{l}200 \text { feet downstream from Katy Trail } \\
\text { Bridge }\end{array}$ \\
\hline
\end{tabular}




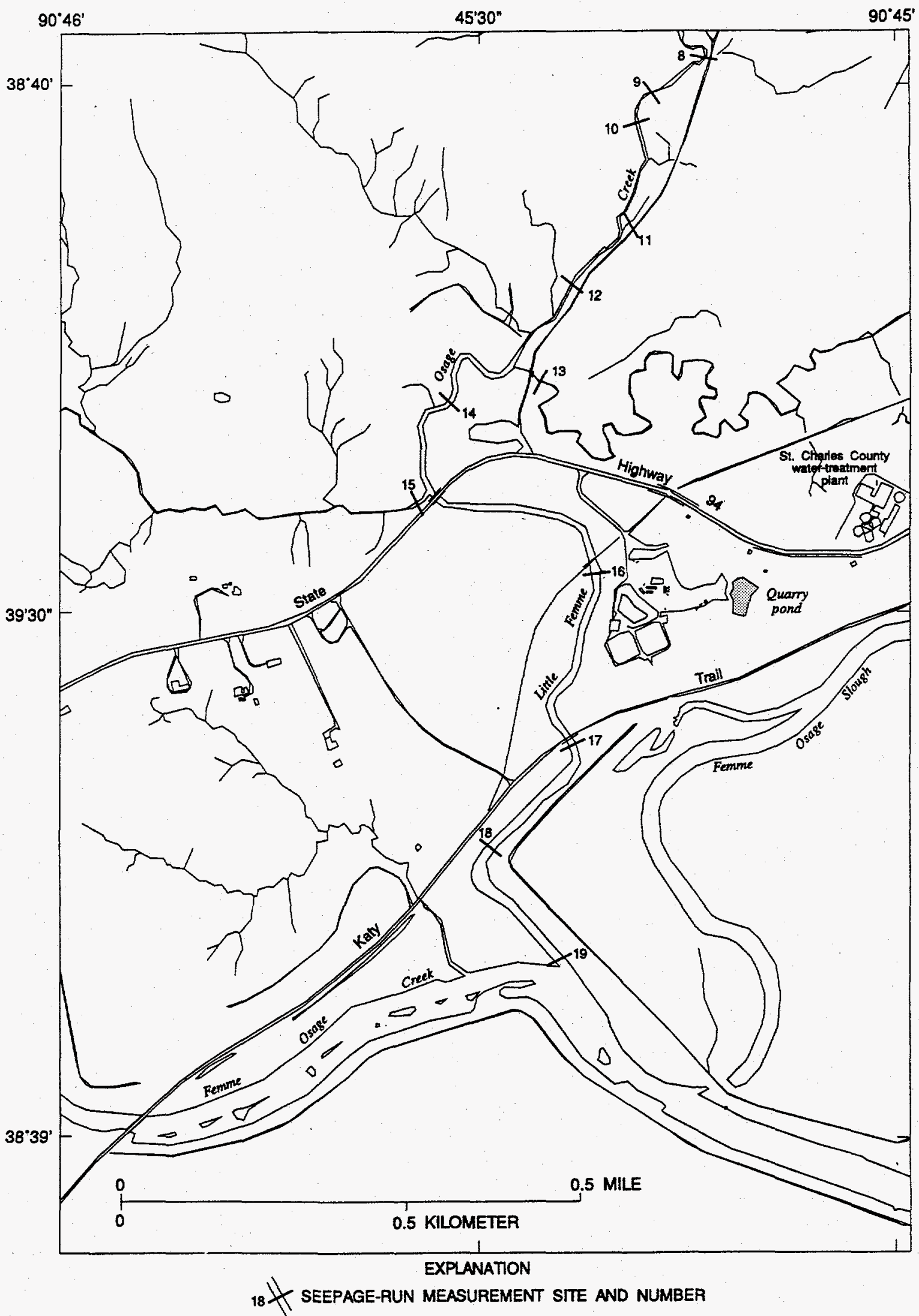

Figure 28. Location of seepage-run measurements on Little Femme Osage Creek, August 24, 1994. 


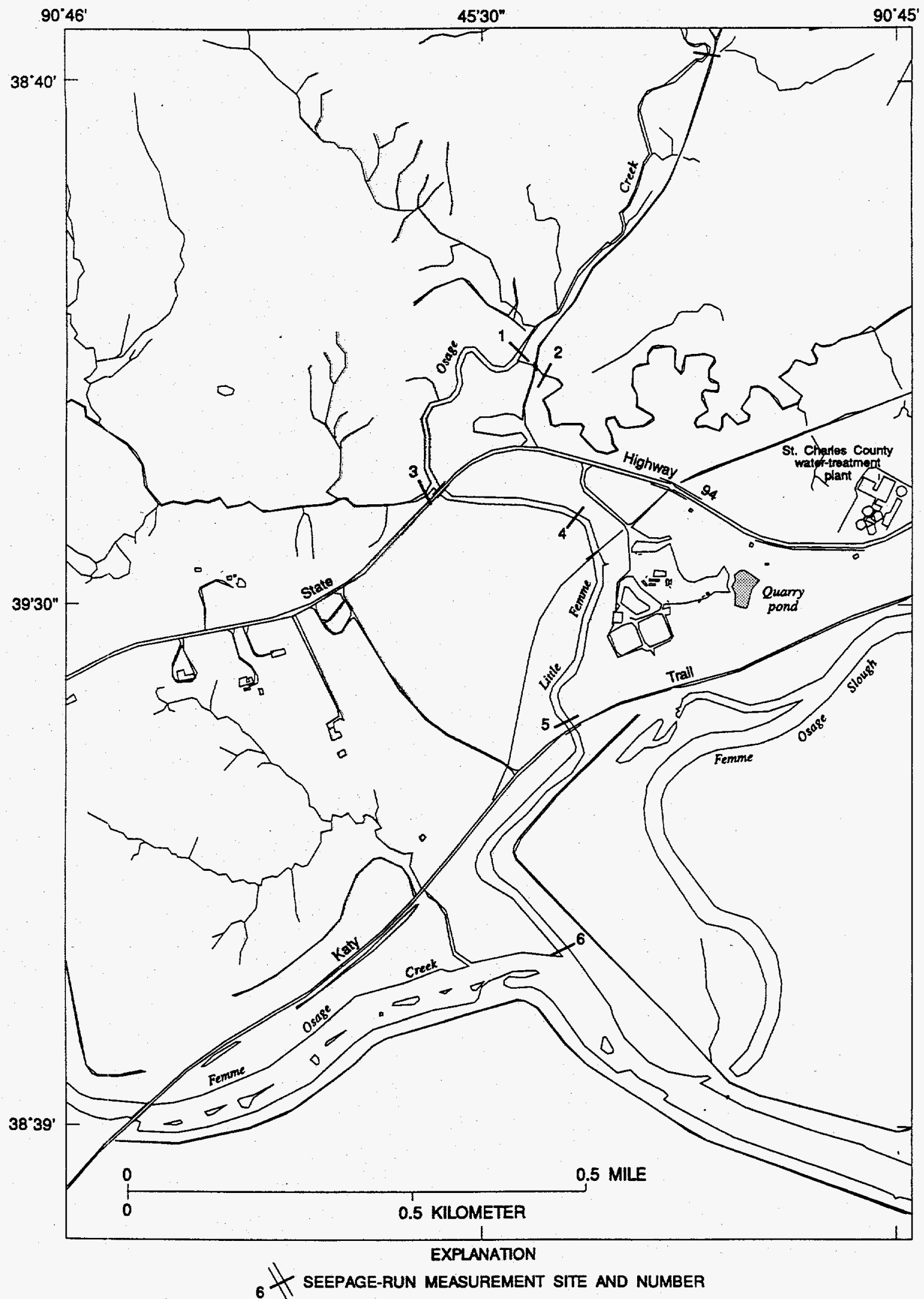

Figure 29. Location of seepage-run measurements on Little Femme Osage Creek, March 17, 1995. 


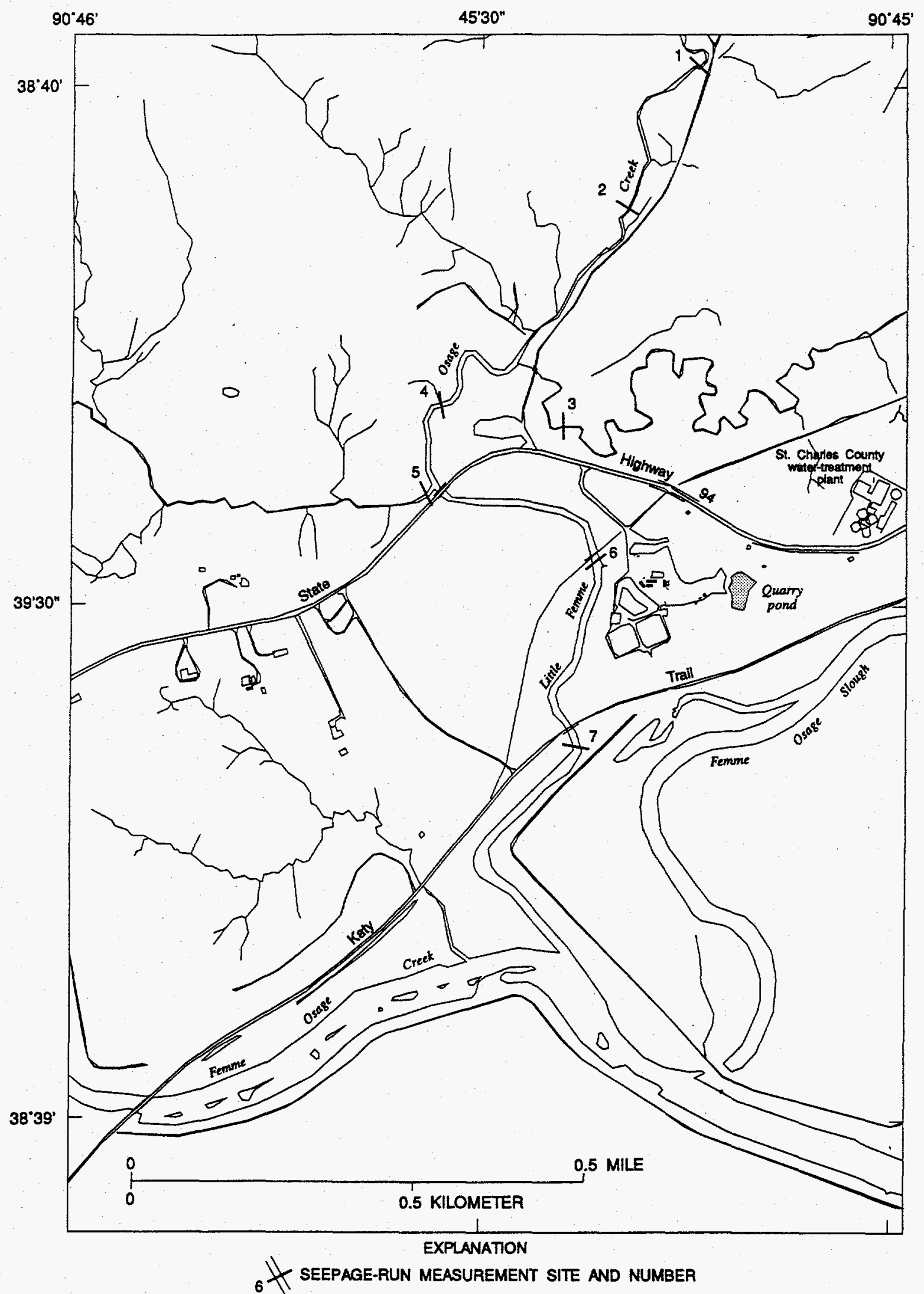

Figure 30. Location of seөpage-run measurements on Little Femme Osage Creek, October 26, 1995. 


\section{SUMMARY AND CONCLUSIONS}

Low-level radioactive waste products from the Weldon Spring chemical plant were transported to an abandoned limestone quarry 3 miles southwest of the chemical plant from 1957 to 1966 . The quarry is cut into permeable, fractured rocks of the Kimmswick Limestone and the Decorah Formation, a few hundred feet north of the Missouri River alluvial plain. Uranium-based contaminants have been detected in alluvial ground water south of the quarry; thus, contaminated ground water could potentially migrate into the St. Charles County well field, which withdraws water from the base of the alluvial aquifer. Water-level measurements were made in 37 piezometers and 19 monitoring wells completed in the bedrock near the abandoned quarry and in the alluvial aquifer south and east of the quarry for about 19 months to assess the potential for ground-water flow from the quarry to the well field.

During all but flood conditions, lateral groundwater flow in the bedrock at and near the quarry, as interpreted from water-table maps, generally is southwest toward Little Femme Osage Creek or southward toward the Missouri River alluvium. Before reaching the creek, the flow direction becomes more southerly, and ground water enters the alluvial aquifer. Flow in the alluvial aquifer south of the quarry generally is southeast to east and between areas of higher watertable altitudes near piezometers WSQ-S7 and WSQ$S 11$. Flow typically continues southeast, then east toward a ground-water depression presumably produced by pumping at the St. Charles County well field. The position of this depression varies depending on the Missouri River stage and probably the number and location of active wells in the St. Charles County well field.

Although water from the quarry generally moves in the direction indicated by two-dimensional water-table maps, the actual flow is three-dimensional. Water from the quarry can potentially flow along bedding planes at the top of the Decorah Formation to the alluvium, then percolate to the water table. The water also can move downward from the quarry into the Plattin Formation and then laterally toward and into the base of the alluvial aquifer. The base of the alluvial aquifer is an area of discharge for regional flow in the Plattin Formation. Ground water also flows from the alluvial aquifer water table downward into more per- meable gravel and sand deposits at the base of the alluvial aquifer.

The Femme Osage Slough is a source of recharge to the alluvial aquifer except during extreme conditions caused by a high Missouri River stage (above $455 \mathrm{ft}$ ). Water levels in Femme Osage Slough typically were higher than the water table in the alluvial aquifer beneath the slough. During floods, the hydraulic head in the base of the aquifer can rise higher than the hydraulic heads near the water table, allowing water from piezometers and wells completed in the lower part of the alluvial aquifer to flow.

Streamflow gains or losses in Little Femme Osage Creek at or near the quarry are minimal. Therefore, there is little exchange of water between the bedrock and Little Femme Osage Creek. Slight fluctuations were measured in stream discharge measurements near the quarry during each of three seepage runs; however, these fluctuations are a result of inherent current meter measurement imprecision, not ground- and surface-water interaction between the bedrock aquifer and stream.

\section{REFERENCES CITED}

Carter, R.W., and Davidian, Jacob, 1968, General procedure for gaging streams: U.S. Geological Survey Techniques of Water-Resources Investigations, book 3 , chap. A6, 13 p.

Hem, J.D., 1985, Study and interpretation of the chemical characteristics of natural water ( $3 \mathrm{~d}$ ed.): U.S. Geological Survey Water-Supply Paper 2254, $263 \mathrm{p}$.

Kleeschulte, M.J., and Emmett, L.F., 1987, Hydrology and water quality at the Weldon Spring radioactive wastedisposal sites, St. Charles County, Missouri: U.S. Geological Survey Water-Resources Investigations Report $87-4169,65$ p.

Kleeschulte, M.J., Emmett, L.F., and Barks, J.H., 1986, Hydrologic data for the Weldon Spring radioactive waste-disposal sites, St. Charles County, Missouri-1984-1986: U.S. Geological Survey Open-File Report 86-488, $61 \mathrm{p}$.

Mugel, D.N., 1993, Geohydrologic data for the St. Charles County well field and public-water supply, 1985-91, and projected public-water supply, 1995 and 2000, for St. Charles County, Missouri: U.S. Geological Survey Open-File Report 93-455, 28 p.

U.S. Department of Energy, 1994, WSSRAP update: St. Charles, Mo., v. 6, no. 2, 8 p. 
TABLES AND ILLUSTRATIONS 
Table 3. Monthly and bi-monthly altitude of water levels in piezometers, selected monitoring wells, and staff gages in the water-level monitoring network [Altitudes are in feet above sea level; $\mathrm{ft}$, feet; ${ }^{* *}$, piezometer not yet drilled or monitoring well not yet added to network; --, no measurement made]

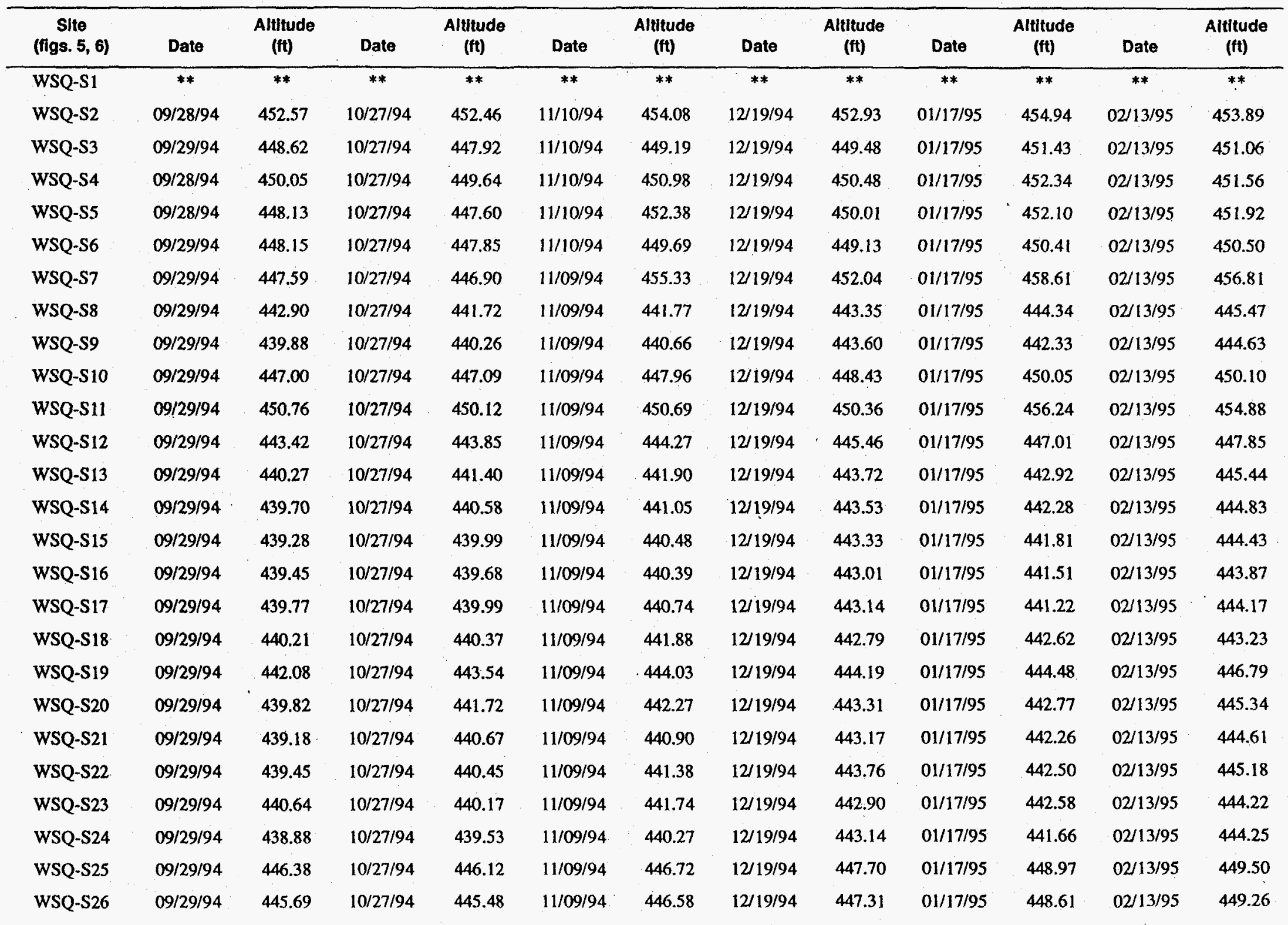


Table 3. Monthly and bi-monthly altitude of water levels in piezometers, selected monitoring wells, and staff gages in the water-level monitoring networkContinued

\begin{tabular}{|c|c|c|c|c|c|c|c|c|c|c|c|c|}
\hline $\begin{array}{c}\text { Site } \\
\text { (figs. 5, 6) }\end{array}$ & Date & $\begin{array}{c}\text { Altitude } \\
\text { (ft) }\end{array}$ & Date & $\begin{array}{c}\text { Altitude } \\
\text { (ft) }\end{array}$ & Date & $\begin{array}{c}\text { Altitude } \\
\text { (ft) }\end{array}$ & Date & $\begin{array}{l}\text { Altltude } \\
\text { (ft) }\end{array}$ & Date & $\begin{array}{c}\text { Altitude } \\
\text { (ft) }\end{array}$ & Date & $\begin{array}{c}\text { Altitude } \\
\text { (ft) }\end{array}$ \\
\hline WSQ-B1 & $* *$ & $* *$ & $* *$ & ** & $* *$ & $* *$ & ** & $* *$ & $* *$ & $* *$ & $* *$ & $* *$ \\
\hline WSQ-B4 & $09 / 29 / 94$ & 441.92 & $10 / 27 / 94$ & 442.79 & $11 / 09 / 94$ & 443.28 & $12 / 19 / 94$ & 444.63 & $01 / 17 / 95$ & 444.41 & $02 / 13 / 95$ & 446.47 \\
\hline WSQ-B6 & $09 / 29 / 94$ & 439.67 & $10 / 27 / 94$ & 440.36 & $11 / 09 / 94$ & 440.82 & $12 / 19 / 94$ & 443.51 & $01 / 17 / 95$ & 442.19 & $02 / 13 / 95$ & 444.68 \\
\hline WSQ-B7 & $* *$ & $* *$ & $* *$ & $* *$ & $* *$ & $* *$ & $* *$ & $* *$ & $* *$ & $* *$ & $* *$ & $* *$ \\
\hline WSQ-B8 & $* *$ & $* *$ & $* *$ & $* *$ & $* *$ & $* *$ & $* *$ & $* *$ & $* *$ & $* *$ & $* *$ & $* *$ \\
\hline WSQ-P2 & $* *$ & $* *$ & $* *$ & $* *$ & $* *$ & $* *$ & $* *$ & $* *$ & $* *$ & $* *$ & $* *$ & $* *$ \\
\hline WSQ-P4 & $* *$ & $* *$ & $* *$ & $* *$ & $* *$ & ** & $* *$ & ** & $* *$ & $* *$ & $* *$ & $* *$ \\
\hline WSQ-P5 & $* *$ & $* *$ & $* *$ & $* *$ & $* *$ & $* *$ & ** & $* *$ & ** & $* *$ & $* *$ & $* * *$ \\
\hline WSQ-P6 & $* *$ & $* *$ & $* *$ & $* *$ & $* *$ & $* *$ & $* *$ & $* *$ & $* *$ & $* *$ & $* *$ & $* *$ \\
\hline WSQ-P8 & $* *$ & $* *$ & $* *$ & $* *$ & $* *$ & $* *$ & $* *$ & $* *$ & ** & $* *$ & $* *$ & $* *$ \\
\hline WSQ-P9 & $* *$ & $* *$ & $* *$ & $* *$ & ** & $* *$ & $* *$ & $* *$ & $* *$ & $* *$ & $* *$ & $* *$ \\
\hline$M W-1002$ & $09 / 30 / 94$ & 467.27 & $10 / 21 / 94$ & 467.38 & $11 / 21 / 94$ & 467.39 & $12 / 20 / 94$ & 467.39 & -- & $-\cdot$ & -- & - \\
\hline MW-1004 & $09 / 30 / 94$ & 461.06 & $10 / 21 / 94$ & 459.29 & $11 / 21 / 94$ & 458.75 & $12 / 20 / 94$ & 458.75 & $\cdots$ & -- & $02 / 14 / 9.5$ & 461.80 \\
\hline MW-1006 & $09 / 29 / 94$ & 449.71 & $10 / 27 / 94$ & 449.12 & $11 / 09 / 94$ & 451.44 & $12 / 19 / 94$ & 450.32 & $01 / 17 / 95$ & 451.75 & $02 / 13 / 95$ & 451.20 \\
\hline MW-1008 & $09 / 29 / 94$ & 449.08 & $10 / 27 / 94$ & 448.47 & $11 / 09 / 94$ & 450.78 & $12 / 19 / 94$ & 449.90 & $01 / 17 / 95$ & 451.57 & $02 / 13 / 95$ & 451.11 \\
\hline MW-1009 & $09 / 29 / 94$ & 447.65 & $10 / 27 / 94$ & 447.10 & $11 / 09 / 94$ & 449.11 & $12 / 19 / 94$ & 448.72 & $01 / 17 / 95$ & 450.28 & $02 / 13 / 95$ & 449.96 \\
\hline MW-1010 & $09 / 29 / 94$ & 439.80 & $10 / 27 / 94$ & 440.07 & $11 / 09 / 94$ & 440.55 & $12 / 19 / 94$ & 443.60 & $01 / 17 / 95$ & 442.04 & $02 / 13 / 95$ & 444.55 \\
\hline MW-1012 & $09 / 08 / 94$ & 460.49 & $10 / 27 / 94$ & 458.20 & $11 / 21 / 94$ & 460.20 & $12 / 20 / 94$ & 458.07 & $01 / 17 / 95$ & 460.46 & $02 / 14 / 95$ & 460.01 \\
\hline MW-1014 & $09 / 29 / 94$ & 446.67 & $10 / 27 / 94$ & 446.45 & $11 / 09 / 94$ & 447.14 & $12 / 19 / 94$ & 447.79 & $01 / 17 / 95$ & 449.13 & $02 / 13 / 95$ & 449.72 \\
\hline MW-1016 & $09 / 29 / 94$ & 450.46 & $10 / 27 / 94$ & 449.97 & $11 / 09 / 94$ & 451.95 & $12 / 19 / 94$ & 450.92 & $01 / 17 / 95$ & $452.50^{\circ}$ & $02 / 13 / 95$ & 451.87 \\
\hline MW-1019 & $* *$ & $* *$ & $* *$ & $* *$ & $* *$ & $* *$ & $* *$ & $* *$ & $* *$ & $* *$ & $02 / 13 / 95$ & 447.33 \\
\hline MW-1021 & $* *$ & $* *$ & $* *$ & $* *$ & $* *$ & $* *$ & $* *$ & $* *$ & $* *$ & $* *$ & $02 / 13 / 95$ & 447.49 \\
\hline MW-1029 & $09 / 08 / 94$ & 470.48 & $10 / 21 / 94$ & 470.18 & $11 / 21 / 94$ & 470.47 & -- & $\cdots$ & -- & -- & $02 / 15 / 95$ & 471.48 \\
\hline MW-1030 & 09/30/94 & 456.56 & -- & - & $11 / 21 / 94$ & 456.61 & $12 / 20 / 94$ & 456.61 & -- & - & $02 / 14 / 95$ & 457.16 \\
\hline MW-1034 & $08 / 15 / 94$ & 462.86 & $10 / 19 / 94$ & 465.75 & -- & -- & $12 / 20 / 94$ & 465.75 & $01 / 17 / 95$ & 465.79 & $02 / 14 / 95$ & 465.82 \\
\hline MW-1035 & $08 / 16 / 94$ & 461.40 & $10 / 12 / 94$ & 460.70 & - & -- & $12 / 20 / 94$ & 461.78 & $01 / 17 / 95$ & 462.19 & $02 / 14 / 95$ & 462.26 \\
\hline
\end{tabular}


Table 3. Monthly and bi-monthly altitude of water levels in piezometers, selected monitoring wells, and staff gages in the water-level monitoring networkContinued

\begin{tabular}{|c|c|c|c|c|c|c|c|c|c|c|c|c|}
\hline $\begin{array}{c}\text { Site } \\
\text { (figs. 5, 6) }\end{array}$ & Date & $\begin{array}{l}\text { Altitude } \\
\text { (ft) }\end{array}$ & Date & $\begin{array}{l}\text { Altitude } \\
\text { (ft) }\end{array}$ & Date & $\begin{array}{l}\text { Altitude } \\
\text { (ft) }\end{array}$ & Date & $\begin{array}{l}\text { Altitude } \\
\text { (tt) }\end{array}$ & Date & $\begin{array}{l}\text { Altitude } \\
\text { (ft) }\end{array}$ & Date & $\begin{array}{l}\text { Altitude } \\
\text { (ft) }\end{array}$ \\
\hline$M W-1036$ & $08 / 16 / 94$ & 456.56 & $10 / 27 / 94$ & 455.80 & $11 / 21 / 94$ & 454.73 & $12 / 20 / 94$ & 455.78 & $01 / 17 / 95$ & 455.83 & $02 / 14 / 95$ & 456.13 \\
\hline$M W-1037$ & $08 / 16 / 94$ & 452.57 & $10 / 27 / 94$ & 451.70 & $11 / 21 / 94$ & 452.78 & $12 / 20 / 94$ & 452.83 & $01 / 17 / 95$ & 454.28 & $02 / 14 / 95$ & 453.88 \\
\hline MW-1038 & 08/16/94 & 454.71 & $10 / 27 / 94$ & 452.81 & $11 / 21 / 94$ & 456.60 & $12 / 20 / 94$ & 454.15 & $01 / 17 / 95$ & 455.80 & $02 / 14 / 95$ & 456.10 \\
\hline MW-1039 & $08 / 12 / 94$ & 457.94 & $10 / 27 / 94$ & 454.69 & -- & -- & -- & -- & $01 / 17 / 95$ & 455.88 & -- & -- \\
\hline WSQ-SGI & 09/29/94 & 451.67 & $10 / 27 / 94$ & 451.63 & $11 / 10 / 94$ & 452.37 & $12 / 19 / 94$ & 451.81 & $01 / 17 / 95$ & 452.09 & $02 / 14 / 95$ & 451.83 \\
\hline WSQ-SG2 & 09/29/94 & 450.54 & $10 / 27 / 94$ & 450.62 & $11 / 10 / 94$ & 451.68 & $12 / 19 / 94$ & 451.00 & $01 / 17 / 95$ & 451.06 & $02 / 13 / 95$ & 450.64 \\
\hline WSQ-SG3 & $09 / 29 / 94$ & 449.35 & $10 / 27 / 94$ & 449.59 & -- & -- & $12 / 19 / 94$ & 449.95 & $01 / 17 / 95$ & 449.87 & $02 / 13 / 95$ & 449.58 \\
\hline WSQ-SG4 & 09/29/94 & 449.84 & $10 / 27 / 94$ & 449.43 & $11 / 10 / 94$ & 449.74 & $12 / 19 / 94$ & 449.67 & $01 / 17 / 95$ & 449.95 & $02 / 13 / 95$ & 450.22 \\
\hline WSQ-SG5 & 09/29/94 & 449.83 & $10 / 27 / 94$ & 449.40 & $11 / 10 / 94$ & 449.73 & $12 / 19 / 94$ & 449.59 & $01 / 17 / 95$ & 449.82 & $02 / 13 / 95$ & 450.20 \\
\hline WSQ-SG6 & 09/29/94 & 449.84 & $10 / 27 / 94$ & 449.40 & $11 / 10 / 94$ & 449.72 & $12 / 19 / 94$ & 449.60 & $01 / 17 / 95$ & 449.96 & $02 / 13 / 95$ & 450.22 \\
\hline WSQ-SG7 & 09/29/94 & 449.84 & $10 / 27 / 94$ & 449.48 & $11 / 10 / 94$ & 449.72 & $12 / 19 / 94$ & 449.55 & $01 / 17 / 95$ & 449.77 & - & -- \\
\hline WSQ-SG8 & 09/29/94 & 443.35 & $10 / 27 / 94$ & 443.34 & $11 / 10 / 94$ & 449.50 & $12 / 19 / 94$ & 443.02 & $01 / 17 / 95$ & 448.63 & $02 / 13 / 95$ & 444.62 \\
\hline
\end{tabular}


Table 3. Monthly and bi-monthly altitude of water levels in piezometers, selected monitoring wells, and staff gages in the water-level monitoring networkContinued

\begin{tabular}{|c|c|c|c|c|c|c|c|c|c|c|c|c|}
\hline $\begin{array}{c}\text { Site } \\
\text { (figs. } 5,6 \text { ) }\end{array}$ & Date & $\begin{array}{l}\text { Altitude } \\
\text { (ft) }\end{array}$ & Date & $\begin{array}{l}\text { Altitude } \\
\text { (it) }\end{array}$ & Date & $\begin{array}{l}\text { Altitude } \\
\text { (tt) }\end{array}$ & Date & $\begin{array}{l}\text { Altitude } \\
\text { (ft) }\end{array}$ & Date & $\begin{array}{l}\text { Altitude } \\
\text { (ft) }\end{array}$ & Date & $\begin{array}{c}\text { Altitude } \\
\text { (ft) }\end{array}$ \\
\hline WSQ-S1 & $* *$ & $* *$ & $* *$ & $* *$ & $* *$ & $* *$ & $* *$ & *** & ** & ** & *** & ** \\
\hline WSQ-S2 & 03/20/95 & 454.02 & 04/19/95 & 453.04 & $05 / 15 / 95$ & 461.91 & $07 / 06 / 95$ & 462.83 & $07 / 27 / 95$ & 460.08 & $08 / 21 / 95$ & 456.70 \\
\hline WSQ-S3 & $03 / 20 / 95$ & 451.01 & $04 / 19 / 95$ & 450.03 & $05 / 15 / 95$ & 455.22 & -- & -- & $-\cdot$ & -- & $08 / 21 / 95$ & 456.25 \\
\hline WSQ-S4 & $03 / 20 / 95$ & 451.68 & $04 / 19 / 95$ & 451.12 & $05 / 15 / 95$ & 455.32 & $07 / 06 / 95$ & 464.08 & $07 / 27 / 95$ & 460.21 & $08 / 21 / 95$ & 456.15 \\
\hline WSQ-S5 & $03 / 20 / 95$ & 451.92 & 04/19/95 & 451.35 & $05 / 15 / 95$ & 455.66 & -- & -- & $07 / 27 / 95$ & 460.29 & $08 / 21 / 95$ & 456.18 \\
\hline WSQ-S6 & $03 / 20 / 95$ & 450.16 & $04 / 19 / 95$ & 449.76 & $05 / 15 / 95$ & 455.63 & -. & -- & -- & -. & $08 / 21 / 95$ & 456.17 \\
\hline WSQ-S7 & 03/20/95 & 456.08 & $04 / 18 / 95$ & 451.88 & $05 / 15 / 95$ & 457.64 & .. & -- & $07 / 26 / 95$ & 460,35 & $08 / 21 / 95$ & 457,85 \\
\hline WSQ-S8 & $03 / 20 / 95$ & 445.12 & $04 / 18 / 95$ & 444.74 & $05 / 15 / 95$ & 454.88 & -. & .- & $m$ & $\because$ & $08 / 21 / 95$ & 455.85 \\
\hline WSQ-S9 & $03 / 20 / 95$ & 442.89 & $04 / 18 / 95$ & 443.61 & $05 / 15 / 95$ & 455.32 & $m$ & $n$ & 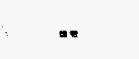 & $=\approx$ & 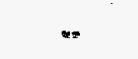 & $=$ \\
\hline WSQ-S10 & $03 / 20 / 95$ & 449.40 & 04/19/95 & 449.41 & $05 / 15 / 95$ & 456.87 & -. & -. & .. & .. & $08 / 21 / 95$ & 455.18 \\
\hline WSQ-S11 & $03 / 20 / 95$ & 454.78 & $04 / 18 / 95$ & 453.12 & $05 / 15 / 95$ & 455.66 &.- & -. & $07 / 26 / 95$ & 460.62 & $08 / 21 / 95$ & 457.37 \\
\hline WSQ-S12 & 03/20/95 & 446.15 & $04 / 18 / 95$ & 446.46 & $05 / 15 / 95$ & 455.30 & -- & - & $07 / 26 / 95$ & 459.72 & $08 / 21 / 95$ & 455.46 \\
\hline WSQ-S13 & 03/20/95 & 443.48 & $04 / 18 / 95$ & 444.19 & $05 / 15 / 95$ & 454.78 &.- & .- & -. & -- & $08 / 21 / 95$ & 454.92 \\
\hline WSQ-S14 & 03/20/95 & 442.96 & $04 / 18 / 95$ & 443.79 & $05 / 15 / 95$ & 454.45 & .. & - & $07 / 26 / 95$ & 460.16 & $08 / 21 / 95$ & 453.87 \\
\hline WSQ-S15 & $03 / 20 / 95$ & 442.30 & $04 / 18 / 95$ & 443.62 & $05 / 15 / 95$ & 454.65 & -. & -- & -- &.- & $08 / 21 / 95$ & 452.33 \\
\hline WSQ-S16 & $03 / 20 / 95$ & 441.40 & $04 / 18 / 95$ & 444.13 & $05 / 15 / 95$ & 455.36 & -- & -- & -- & -- & $08 / 21 / 95$ & 450.95 \\
\hline WSQ-S17 & $03 / 20 / 95$ & 441.96 & 04/18/95 & 444.76 & $05 / 15 / 95$ & 455.53 & .- & - & -- & -- & $08 / 21 / 95$ & 453.19 \\
\hline WSQ-S18 & $03 / 20 / 95$ & 441.12 & $04 / 18 / 95$ & 445.07 & $05 / 15 / 95$ & 456.76 & -- & -- & -- & -. & $08 / 21 / 95$ & 449.33 \\
\hline WSQ-S19 & $03 / 20 / 95$ & 444.94 & $04 / 18 / 95$ & 445.25 & $05 / 15 / 95$ & 455.14 & -- & -- & 07/20/95 & 460.00 & $08 / 21 / 95$ & 454.29 \\
\hline WSQ-S20 & $03 / 20 / 95$ & 443.40 & $04 / 18 / 95$ & 444.32 & $05 / 15 / 95$ & 455.10 &.- & $\therefore$ & -- & -- & $08 / 21 / 95$ & 452.89 \\
\hline WSQ-S21 & $03 / 20 / 95$ & 442.87 & $04 / 18 / 95$ & 443.86 & $05 / 15 / 95$ & 454.79 & -. & -- & - & -- & $08 / 21 / 95$ & 452.80 \\
\hline WSQ-S22 & 03/20/95 & 442.93 & $04 / 18 / 95$ & 445.07 & 05/15/95 & 456.78 & -- & -- & $07 / 26 / 95$ & 458.17 & $08 / 21 / 95$ & 450.20 \\
\hline WSQ-S23 & $03 / 20 / 95$ & 441.88 & $04 / 18 / 95$ & 445.21 & $05 / 15 / 95$ & 457.37 & -- & -- & $07 / 26 / 95$ & 458.29 & $08 / 21 / 95$ & 449.25 \\
\hline WSQ-S24 & $03 / 20 / 95$ & 441.53 & $04 / 18 / 95$ & 443.60 & $05 / 15 / 95$ & 455.50 & - & -- & 07/26/95 & 459.64 & $08 / 21 / 95$ & 450.34 \\
\hline WSQ-S25 & $03 / 20 / 95$ & 448.74 & 04/19/95 & 448.32 & $05 / 15 / 95$ & 455.41 & -- & -- & $07 / 27 / 95$ & 460.23 & $08 / 21 / 95$ & 455.94 \\
\hline WSQ-S26 & $03 / 20 / 95$ & 448.49 & - & -- & -- & - & -. & -. & -. & -- & -- & -- \\
\hline
\end{tabular}


Table 3. Monthly and bi-monthly altitude of water levels in piezometers, selected monitoring wells, and staff gages in the water-level monitoring networkContinued

\begin{tabular}{|c|c|c|c|c|c|c|c|c|c|c|c|c|}
\hline $\begin{array}{c}\text { Site } \\
\text { (figs. 5, 6) }\end{array}$ & Date & $\begin{array}{l}\text { Altitude } \\
\text { (ft) }\end{array}$ & Date & $\begin{array}{l}\text { Altitude } \\
\text { (ft) }\end{array}$ & Date & $\begin{array}{l}\text { Altitude } \\
\text { (ft) }\end{array}$ & Date & $\begin{array}{l}\text { Altitude } \\
\text { (ft) }\end{array}$ & Date & $\begin{array}{l}\text { Altitude } \\
\text { (ft) }\end{array}$ & Date & $\begin{array}{l}\text { Altitude } \\
\text { (ft) }\end{array}$ \\
\hline WSQ-B4 & $03 / 20 / 95$ & 444.77 & 04/19/95 & 445.34 & $05 / 15 / 95$ & 455.16 &.- & -. & $07 / 26 / 95$ & 459.63 & $08 / 21 / 95$ & 454.85 \\
\hline WSQ-B7 & $* *$ & $* *$ & $* *$ & $* *$ & $* *$ & $* *$ & $* *$ & $* *$ & $* *$ & $* *$ & $* *$ & $* *$ \\
\hline WSQ-B8 & $* *$ & $* *$ & $* *$ & $* *$ & $* *$ & $* *$ & $* *$ & $* *$ & $* *$ & $* *$ & $* *$ & $* *$ \\
\hline WSQ-PS & $* *$ & $* *$ & $* *$ & $* *$ & $* *$ & $* *$ & $* *$ & $* *$ & $* *$ & $* *$ & $* *$ & $* *$ \\
\hline WSQ-P6 & $* *$ & $* *$ & $* *$ & $* *$ & $* *$ & $* *$ & $* *$ & $* *$ & ** & $* *$ & $* *$ & $* *$ \\
\hline WSQ-P8 & $* *$ & $* *$ & $* *$ & $* *$ & $* *$ & $* *$ & $* *$ & ** & $* *$ & $* *$ & $* *$ & $* *$ \\
\hline WSQ-P9 & $* *$ & $* *$ & $* *$ & $* *$ & $* *$ & $* *$ & $* *$ & $* *$ & $* *$ & $* *$ & $* *$ & $* *$ \\
\hline MW-1002 & $03 / 21 / 95$ & 468.34 & 04/19/95 & 468.18 & $05 / 17 / 95$ & 471.36 & 07/06/95 & 469.75 & $07 / 27 / 95$ & 469.45 & $08 / 21 / 95$ & 468.49 \\
\hline$M W-1009$ & $03 / 20 / 95$ & 450.07 & 04/19/95 & 449.49 & $\because$ & - & - & - & - & -- & -- & -- \\
\hline MW-1010 & $03 / 20 / 95$ & 442.38 & 04/19/95 & 443.79 & $05 / 15 / 95$ & 455.01 & -- & -. & -- & - & $08 / 21 / 95$ & 453.43 \\
\hline MW-1012 & $03 / 20 / 95$ & 459.25 & 04/19/95 & 457.76 & $05 / 15 / 95$ & 462.15 & $07 / 06 / 95$ & 461.83 & $07 / 27 / 95$ & 459.29 & $08 / 21 / 95$ & 458.96 \\
\hline MW-1014 & $03 / 20 / 95$ & 449.12 & 04/19/95 & 448.73 & $05 / 15 / 95$ & 455.72 & -- & - & - & -- & $08 / 21 / 95$ & 455.80 \\
\hline MW-1016 & 03/20/95. & 451.99 & 04/19/95 & 451.32 & 05/15/95 & 456.25 & -. & -- & -- & -- & -- & -- \\
\hline MW-1019 & 03/20/95 & 445.63 & 04/18/95 & 447.24 & $05 / 15 / 95$ & 455.49 & -- & $-\cdot$ & $07 / 26 / 95$ & 458.99 & $08 / 21 / 95$ & 454.89 \\
\hline MW-1021 & $04 / 03 / 95$ & 445.99 & $04 / 18 / 95$ & 446.60 & $05 / 15 / 95$ & 455.70 & -- & -- & $\cdots$ & -- & - & $-\cdot$ \\
\hline MW-1029 & $03 / 21 / 95$ & 471.90 & $04 / 19 / 95$ & 471.20 & $05 / 17 / 95$ & 472.12 & $07 / 06 / 95$ & 471.85 & 07/27/95 & 471.25 & $08 / 21 / 95$ & 470.98 \\
\hline MW-1030 & $03 / 21 / 95$ & 457.19 & $04 / 19 / 95$ & 457.18 & $05 / 17 / 95$ & 458.82 & $07 / 06 / 95$ & 463.88 & 07/27/95 & 460.49 & $08 / 21 / 95$ & 457.18 \\
\hline MW-1034 & $03 / 20 / 95$ & 465.83 & $04 / 19 / 95$ & 465.79 & $05 / 15 / 95$ & 465.91 & 07/06/95 & 467.16 & $07 / 27 / 95$ & 466.34 & $08 / 21 / 95$ & 465.83 \\
\hline
\end{tabular}




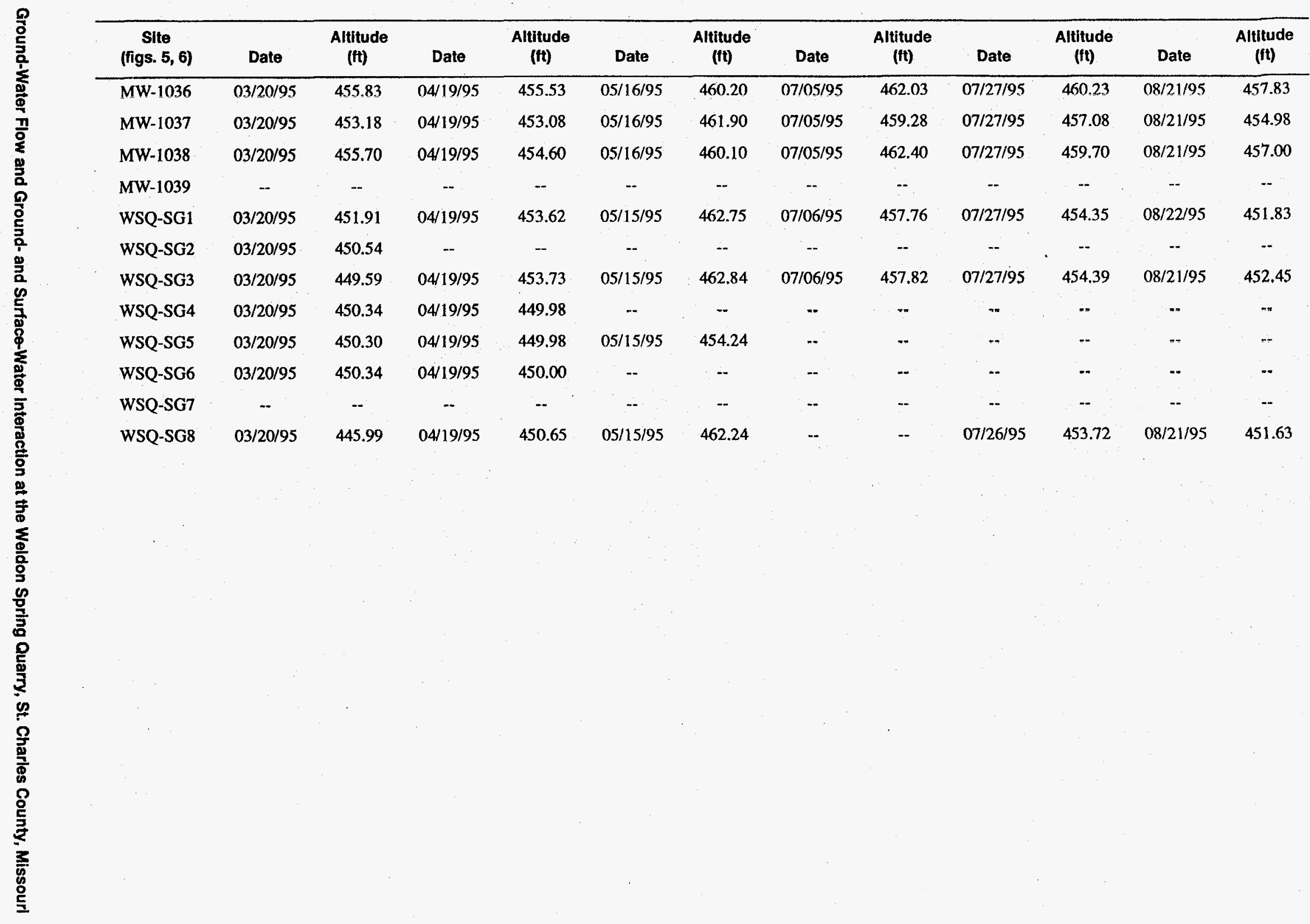


Table 3. Monthly and bi-monthly altitudes of water levels in piezometers, selected monitoring wells, and staff gages in the water-level monitoring networkContinued

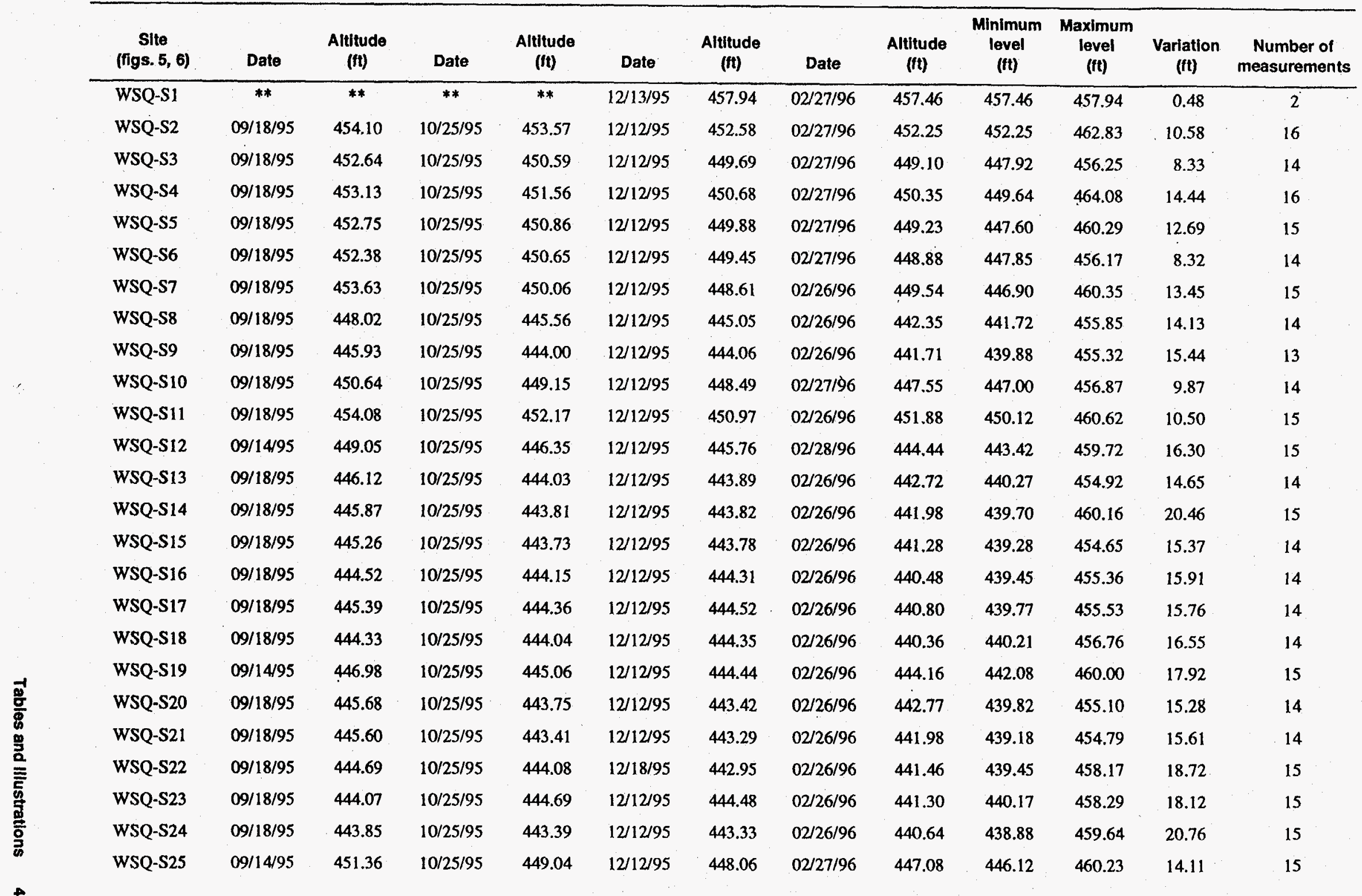


Table 3. Monthly and bi-monthly altitudes of water levels in piezometers, selected monitoring wells, and staff gages in the water-level monitoring networkContinued

\begin{tabular}{|c|c|c|c|c|c|c|c|c|c|c|c|c|}
\hline $\begin{array}{c}\text { Site } \\
\text { (figs. 5, 6) }\end{array}$ & Date & $\begin{array}{l}\text { Altitude } \\
\text { (ft) }\end{array}$ & Date & $\begin{array}{c}\text { Altitude } \\
\text { (ft) }\end{array}$ & Date & $\begin{array}{l}\text { Altitude } \\
\text { (ft) }\end{array}$ & Date & $\begin{array}{l}\text { Altitude } \\
\text { (ft) }\end{array}$ & $\begin{array}{c}\text { Minimum } \\
\text { level } \\
\text { (ft) }\end{array}$ & $\begin{array}{l}\text { Maximum } \\
\text { level } \\
\text { (ft) }\end{array}$ & $\begin{array}{c}\text { Variation } \\
\text { (ft) }\end{array}$ & $\begin{array}{c}\text { Number of } \\
\text { measurements }\end{array}$ \\
\hline WSQ-S26 & $09 / 18 / 95$ & 450.86 & $10 / 25 / 95$ & 448.60 & $12 / 12 / 95$ & 447.70 & $02 / 27 / 96$ & 446.49 & 445.48 & 450.86 & 5.38 & 11 \\
\hline WSQ-BI & $* *$ & $* *$ & $* *$ & $* *$ & $12 / 12 / 95$ & 443.84 & $02 / 26 / 96$ & 442.41 & 442.41 & 443.84 & 1.43 & 2. \\
\hline WSQ-B4 & $09 / 14 / 95$ & 447.76 & $10 / 25 / 95$ & 445.33 & $12 / 12 / 95$ & 444.94 & $02 / 26 / 96$ & 443.86 & 441.92 & 459.63 & 17.71 & 15 \\
\hline WSQ-B6 & $09 / 18 / 95$ & 445.87 & $10 / 25 / 95$ & 443.99 & $12 / 12 / 95$ & 444.02 & $02 / 26 / 96$ & 441.81 & 439.67 & 454.73 & 15.06 & 13 \\
\hline WSQ-B7 & $* *$ & $* *$ & $* *$ & $* *$ & $12 / 12 / 95$ & 443.44 & $02 / 26 / 96$ & 442.92 & 442.92 & 443.44 & .52 & 2 \\
\hline WSQ-B8 & $* *$ & ** & $* *$ & $* *$ & $12 / 12 / 95$ & 443.68 & $02 / 26 / 96$ & 441.18 & 441.18 & 443.68 & 2.50 & 2 \\
\hline WSQ-P2 & ** & $* *$ & ** & $* *$ & $12 / 12 / 95$ & ${ }^{1} 415.87$ & $02 / 27 / 96$ & ${ }^{1} 440.96$ & 415.87 & 440.96 & 25.09 & 2 \\
\hline WSQ-P4 & $* *$ & $* *$ & $* *$ & $* *$ & $12 / 12 / 95$ & ${ }^{1} 356.00$ & $02 / 27 / 96$ & ${ }^{1} 364.50$ & 356.00 & 364.50 & 8.50 & 2 \\
\hline WSQ-P5 & $* *$ & $* *$ & $* *$ & $* *$ & $12 / 12 / 95$ & 443.85 & $02 / 26 / 96$ & 442.36 & 442.36 & 443.85 & 1.49 & 2 \\
\hline WSQ-P6 & $* *$ & $* *$ & $* *$ & $* *$ & $* *$ & $* *$ & $02 / 27 / 96$ & ${ }^{1} 382.81$ & 382.81 & 382.81 & 0 & 1 \\
\hline WSQ-P8 & ** & $* *$ & $* *$ & $* *$ & $12 / 12 / 95$ & 445.63 & $02 / 28 / 96$ & 444.56 & 444.56 & 445.63 & 1.07 & 2 \\
\hline WSQ-P9 & $* *$ & $* *$ & $* *$ & $* *$ & $12 / 12 / 95$ & ${ }^{1} 367.45$ & $02 / 26 / 96$ & ${ }^{1} 378.09$ & 367.45 & 378.09 & 10.64 & 2 \\
\hline MW-1002 & 09/19/95 & 468.03 & $10 / 23 / 95$ & 467.57 & $12 / 13 / 95$ & 467.27 & $02 / 28 / 96$ & 467.25 & 467.25 & 471.36 & 4.11 & 14 \\
\hline MW-1004 & 09/19/95 & 461.41 & $10 / 23 / 95$ & 461.48 & $12 / 13 / 95$ & 461.27 & $02 / 28 / 96$ & 460.24 & 458.75 & 464.15 & 5.40 & 15 \\
\hline MW-1006 & 09/18/95 & 453.27 & $10 / 25 / 95$ & 451.58 & $12 / 12 / 95$ & 450.62 & $02 / 27 / 96$ & 450.11 & 449.12 & 453.27 & 4.15 & 12 \\
\hline MW-1008 & 09/18/95 & 453.14 & $10 / 25 / 95$ & 451.30 & $12 / 12 / 95$ & 450.22 & $02 / 27 / 96$ & 449.59 & 448.47 & 453.14 & 4.67 & 12 \\
\hline MW-1009 & $09 / 18 / 95$ & 452.66 & $10 / 25 / 95$ & 450.23 & $12 / 12 / 95$ & 449.47 & $02 / 27 / 96$ & 448.61 & 447.10 & 452.66 & 5.56 & 12 \\
\hline MW-1010 & 09/18/95 & 446.06 & $10 / 25 / 95$ & 444.33 & $12 / 12 / 95$ & 444.28 & $02 / 26 / 96$ & 441.25 & 439.80 & 455.01 & 15.21 & 14 \\
\hline MW-1012 & 09/18/95 & 458.12 & $10 / 26 / 95$ & 458.76 & $12 / 13 / 95$ & 458.69 & $02 / 26 / 96$ & 458.46 & 457.76 & 462.15 & 4.39 & 16 \\
\hline MW-1014 & 09/18/95 & 451.07 & 10/25/95 & 449.00 & $12 / 12 / 95$ & 448.02 & $02 / 27 / 96$ & 447.08 & 446.45 & 455.80 & 9.35 & 14 \\
\hline MW-1016 & 09/18/95 & 453.85 & $10 / 25 / 95$ & 452.19 & $12 / 12 / 95$ & 451.36 & $02 / 27 / 96$ & 450.80 & 449.97 & 456.25 & 6.28 & 13 \\
\hline MW-1019 & $09 / 14 / 95$ & 448.61 & $10 / 25 / 95$ & 446.36 & $12 / 12 / 95$ & 443.68 & $02 / 28 / 96$ & 442.67 & 442.67 & 458.99 & 16.32 & 10 \\
\hline MW-1021 & -- & -- & $10 / 25 / 95$ & 446.60 & $12 / 12 / 95$ & 445.99 & $02 / 26 / 96$ & 445.00 & 445.00 & 455.70 & 10.70 & 7 \\
\hline MW-1029 & 09/19/95 & 470.71 & $10 / 23 / 95$ & 470.29 & $12 / 13 / 95$ & 470.13 & $02 / 28 / 96$ & 470.32 & 470.13 & 472.12 & 1.99 & 14 \\
\hline MW-1030 & 09/19/95 & 457.19 & $10 / 23 / 95$ & 457.21 & $12 / 05 / 95$ & 457.19 & $02 / 28 / 96$ & 456.18 & 456.18 & 463.88 & 7.70 & 14 \\
\hline$M W-1034$ & 09/18/95 & 465.81 & $10 / 26 / 95$ & 465.79 & $12 / 13 / 95$ & 465.69 & $02 / 27 / 96$ & 465.67 & 462.86 & 467.16 & 4.30 & 15 \\
\hline
\end{tabular}


Table 3. Monthly and bi-monthly altitudes of water levels in piezometers, selected monitoring wells, and staff gages in the water-level monitoring networkContinued

\begin{tabular}{|c|c|c|c|c|c|c|c|c|c|c|c|c|}
\hline $\begin{array}{c}\text { Site } \\
\text { (figs. } 5,6)\end{array}$ & Date & $\begin{array}{l}\text { Altitude } \\
\text { (it) }\end{array}$ & Date & $\begin{array}{l}\text { Altitude } \\
\text { (it) }\end{array}$ & Date & $\begin{array}{l}\text { Altitude } \\
\text { (ii) }\end{array}$ & Date & $\begin{array}{l}\text { Altitude } \\
\text { (ft) }\end{array}$ & $\begin{array}{c}\text { Minimum } \\
\text { level } \\
\text { (ft) }\end{array}$ & $\begin{array}{l}\text { Maximum } \\
\text { level } \\
\text { (ft) }\end{array}$ & $\begin{array}{c}\text { Variation } \\
\text { (ft) }\end{array}$ & $\begin{array}{c}\text { Number of } \\
\text { measurements }\end{array}$ \\
\hline$M W-1035$ & $09 / 18 / 95$ & 461.50 & $10 / 26 / 95$ & 461.20 & $12 / 13 / 95$ & 460.86 & $02 / 27 / 96$ & 461.09 & 460.70 & 464.69 & 3.99 & 15 \\
\hline MW-1036 & $09 / 19 / 95$ & 457.13 & $10 / 26 / 95$ & 456.23 & $12 / 12 / 95$ & 455.50 & $02 / 27 / 96$ & 453.90 & 453.90 & 462.03 & 8.13 & 16 \\
\hline MW-1037 & $09 / 19 / 95$ & 452.98 & $10 / 26 / 95$ & 451.88 & $12 / 12 / 95$ & 452.40 & $02 / 27 / 96$ & 452.65 & 451.70 & 461.90 & 10.20 & 16 \\
\hline MW-1038 & $09 / 19 / 95$ & 454.90 & - & - & $12 / 12 / 95$ & 452.70 & $02 / 27 / 96$ & 455.25 & 452.70 & 462.40 & 9.70 & 15 \\
\hline MW-1039 & -- & - & $\cdots$ & -- & $\cdots$ & - & - & -- & 454.69 & 457.94 & 3.25 & 3 \\
\hline WSQ-SG1 & $09 / 18 / 95$ & 451.72 & $10 / 25 / 95$ & 451.89 & $12 / 13 / 95$ & 451.88 & $02 / 27 / 96$ & 451.75 & 451.63 & 462.75 & 11.12 & 16 \\
\hline WSQ-SG2 & -- & -- & - & -- & $\cdots$ & - & -- & -- & 450.54 & 451.68 & 1.14 & 7 \\
\hline WSQ-SG3 & $09 / 18 / 95$ & 449.38 & $10 / 25 / 95$ & 449.45 & $12 / 12 / 95$ & 449.87 & $02 / 27 / 96$ & 449.41 & 449.35 & 462.84 & 13.49 & 15 \\
\hline WSQ-SG4 & -- & - & -- & -- & $12 / 12 / 95$ & 450.54 & $02 / 27 / 96$ & 449.98 & 449.43 & 450.54 & 1.11 & 10 \\
\hline WSQ-SGS & $09 / 18 / 95$ & 452.98 & $10 / 25 / 95$ & 451.35 & $12 / 12 / 95$ & 450.53 & $02 / 27 / 96$ & 449.96 & 449.40 & 454.24 & 4.84 & 13 \\
\hline WSQ-SG6 & -- & -- & $10 / 25 / 95$ & 451.36 & $12 / 12 / 95$ & 450.51 & $02 / 27 / 96$ & 450.00 & 449.40 & 451.36 & 1.96 & 11 \\
\hline WSQ-SG7 & - & - & $10 / 25 / 95$ & 451.40 & $12 / 12 / 95$ & 450.58 & $02 / 26 / 96$ & 449.99 & 449.48 & 451.40 & 1.92 & 8 \\
\hline WSQ-SG8 & $09 / 18 / 95$ & 447.69 & $10 / 25 / 95$ & 447.48 & $12 / 12 / 95$ & 446.72 & $02 / 26 / 96$ & 445.31 & 443.02 & 462.24 & 19.22 & 15 \\
\hline
\end{tabular}

'Water level in piezometer had not reached static water-level conditions. 
Table 4. Daily mean water-level altitudes for piezometer WSQ-S12

[Station number 383920090450601; latitude 383920; longitude 0904506; piezometer depth 21.3 feet; altitudes are in feet above sea level;,-- no data]

\begin{tabular}{|c|c|c|c|c|c|c|c|c|}
\hline \multirow[b]{2}{*}{ Day } & \multicolumn{3}{|c|}{1994} & \multicolumn{5}{|c|}{1995} \\
\hline & Oct & Nov & Dec & Jan & Feb & Mar & Apr & May \\
\hline 1 & -- & -- & 446.22 & 444.81 & 447.48 & 446.24 & 446.78 & 449.59 \\
\hline 2 & -. & - & 446.21 & 444.77 & 447.36 & 446.18 & 446.60 & 450.57 \\
\hline 3 & -. & $\ldots$ & 446.06 & 444.68 & 447.66 & 446.17 & 446.48 & 450.95 \\
\hline 4 &.- & - & 445.98 & 444.59 & 448.31 & 446.12 & 446.14 & 451.23 \\
\hline 5 & -- & - & 445.89 & 444.77 & 448.45 & 446.06 & 446.31 & 451.57 \\
\hline 6 & -- & -- & 445.95 & 444.95 & 448.51 & 445.92 & 446.26 & 451.92 \\
\hline 7 & -. & -- & 445.77 & 444.43 & 448.37 & 447.46 & 446.13 & 452.16 \\
\hline 8 & -- & -- & 445.79 & 444.38 & 448.14 & 448.77 & 446.09 & 452.61 \\
\hline 9 & - & -- & 445.78 & 444.33 & 448.36 & 448.47 & 445.85 & 453.15 \\
\hline 10 & $\because$ & $\ldots$ & 445.78 & 444.42 & 448.22 & 448.12 & 445.72 & 453.50 \\
\hline 11 & - & -- & 445.70 & 444.49 & 447.87 & 447.78 & 445.70 & 453.88 \\
\hline 12 & -- &.- & 445.79 & 444.33 & 447.81 & 447.46 & 445.58 & 454.47 \\
\hline 13 & - & - & 445.68 & 444.65 & 447.81 & 447.13 & 445.59 & 454.98 \\
\hline 14 & -- & -- & 445.65 & 447.06 & 447.82 & 446.88 & 445.91 & 455.03 \\
\hline 15 & -- & -- & 445.59 & 447.32 & 447.67 & 446.71 & 446.09 & 455.31 \\
\hline 16 & -- & -- & 445.66 & 447.18 & 447.24 & 446.51 & 446.09 & 455.67 \\
\hline 17 & -- & -- & 445.51 & 446.95 & 447.17 & 446.29 & 446.23 & 457.49 \\
\hline 18 & -- & -- & 445.36 & 446.71 & 447.25 & 446.21 & 446.44 & -- \\
\hline 19 & -- & 444.44 & 445.42 & 447.48 & 447.12 & 446.22 & 446.20 & -- \\
\hline 20 & -- & 444.77 & 445.37 & 447.82 & 447.08 & 446.16 & 447.08 & -- \\
\hline 21 & -- & 444.64 & 445.31 & 447.77 & 446.82 & 446.16 & 447.61 & -- \\
\hline 22 & - & 444.75 & 445.63 & 447.59 & 446.95 & 446.30 & 447.71 & -- \\
\hline 23 & -- & 445.21 & 445.85 & 447.32 & 446.67 & 446.12 & 447.95 & -- \\
\hline 24 & -- & 445.63 & 445.82 & 447.09 & 446.49 & 446.09 & 448.09 & -- \\
\hline 25 & $\cdots$ & 445.70 & 445.70 & 446.99 & 446.75 & 446.14 & 448.19 & -- \\
\hline 26 & - & 445.89 & 445.58 & 446.93 & 446.55 & 446.27 & 448.43 & -- \\
\hline 27 & -- & 446.25 & 445.46 & 447.13 & 446.44 & 446.51 & 448.31 & - \\
\hline 28 & -- & 445.91 & 445.25 & 447.08 & 446.27 & 446.72 & 448.47 & -- \\
\hline 29 & -- & 445.92 & 445.14 & 447.05 & - & 446.78 & 448.65 & -- \\
\hline 30 & -- & 446.05 & 445.07 & 447.28 & - & 446.78 & 448.92 & -. \\
\hline 31 & -- & -- & 445.02 & 447.50 & -- & 446.81 & -- & -- \\
\hline MEAN & $-\cdot$ & 445.43 & 445.64 & 446.12 & 447.45 & 446.69 & 446.85 & 453.18 \\
\hline MAXIMUM & -- & 446.25 & 446.22 & 447.82 & 448.51 & 448.77 & 448.92 & 457.49 \\
\hline MINIMUM & -- & 444.44 & 445.02 & 444.33 & 446.27 & 445.92 & 445.58 & 449.59 \\
\hline
\end{tabular}


Table 4. Daily mean water-level altitudes for piezometer WSQ-S12-Continued

\begin{tabular}{|c|c|c|c|c|c|c|c|c|c|}
\hline \multirow[b]{2}{*}{ Day } & \multicolumn{7}{|c|}{1995} & \multicolumn{2}{|c|}{1996} \\
\hline & June & July & Aug & Sept & Oat & Nov & Dec & Jan & Feb \\
\hline 1 & -- & -- & 458.17 & 452.27 & 447.48 & 446.83 & 446.42 & 444.84 & 444.43 \\
\hline 2 &.- & -- & 458.40 & 451.80 & 447.47 & 446.74 & 446.35 & 444.94 & 444.41 \\
\hline 3 & -. & - & 458.31 & 451.44 & 447.51 & 446.70 & 446.15 & 444.82 & 444.51 \\
\hline 4 & -- &.- & 458.17 & 451.10 & 447.48 & 446.76 & 446.12 & 444.82 & 444.56 \\
\hline 5 & -- & -- & 458.10 & 450.72 & 447.49 & 446.96 & 446.09 & 444.57 & 444.73 \\
\hline 6 & -- & -- & 457.95 & 450.50 & 447.27 & 447.16 & 445.99 & 444.66 & 444.75 \\
\hline 7 & -- & $\therefore$ & 458.79 & 450.34 & 447.12 & 446.93 & 445.99 & 444.99 & 444.89 \\
\hline 8 & -- & $\cdots$ & 458.73 & 450.15 & 447.18 & 447.13 & 446.04 & 444.71 & 444.75 \\
\hline 9 & -- & -- & 458.30 & 450.02 & 447.13 & 447.85 & 445.78 & 444.64 & 444.65 \\
\hline 10 & -- & -- & 458.00 & 449.81 & 446.97 & 447.51 & 445.84 & 444.44 & 444.67 \\
\hline 11 & -- & - & 457.77 & 449.67 & 447.00 & 447.12 & 445.93 & 444.60 & 444.44 \\
\hline 12 & - & -- & 457.34 & 449.52 & 447.03 & 447.29 & 445.81 & .444 .48 & .444 .41 \\
\hline 13 & - & -- & 457.07 & 449.30 & 447.04 & 447.17 & 445.88 & 444.81 & 444.77 \\
\hline 14 & -- & - & 456.73 & 449.07 & 446.89 & 447.14 & 445.63 & 444.90 & 444.67 \\
\hline 15 & -- & -- & 456.43 & 448.99 & 446.90 & 447.17 & 445.48 & 444.64 & 444.46 \\
\hline 16 & - & -- & 456.31 & 448.98 & 446.73 & 447.17 & 445.43 & 444.90 & 444.44 \\
\hline 17 & - & -- & 456.31 & 448.84 & 446.78 & 447.23 & 445.46 & 444.80 & 444.76 \\
\hline 18 & $\cdots$ & -- & 456.10 & 448.65 & 446.76 & 447.09 & 445.43 & 444.96 & 444.74 \\
\hline 19 & -- & -- & 455.92 & 448.64 & 446.64 & 446.95 & 445.73 & 445.30 & 444.83 \\
\hline 20 & -- & -- & 455.75 & 448.46 & 446.57 & 446.78 & 445.57 & 445.21 & 444.72 \\
\hline 21 & -- & 460.72 & 455.49 & 448.34 & 446.59 & 446.73 & 445.47 & 444.98 & 444.59 \\
\hline 22 & $\cdots$ & 460.52 & 455.18 & 448.28 & 446.56 & 446.81 & 445.26 & 444.90 & 444.90 \\
\hline 23 & $\cdots$ & 460.31 & 454.95 & 448.26 & 446.48 & 446.58 & 445.17 & 445.22 & 444.82 \\
\hline 24 & - & 460.11 & 454.74 & 448.21 & 446.23 & 446.53 & 445.19 & 445.61 & 444.57 \\
\hline 25 & -- & 459.91 & 454.44 & 448.13 & 446.36 & 446.74 & 445.10 & 445.58 & 444.80 \\
\hline 26 & -- & 459.68 & 454.14 & 447.99 & 446.56 & 446.88 & 445.14 & 445.39 & 444.85 \\
\hline 27 & -- & 459.57 & 453.86 & 447.83 & 446.47 & 446.66 & 444.95 & 444.77 & 444.71 \\
\hline 28 & $\cdots$ & 459.17 & 453.26 & 447.72 & 446.16 & 446.27 & 444.88 & 444.92 & - \\
\hline 29 & -. & 458.91 & 453.10 & 447.73 & 446.20 & 446.42 & 444.92 & 444.69 & - \\
\hline 30 & -- & 458.67 & 452.95 & 447.70 & 446.37 & 446.61 & 445.03 & 444.48 & -- \\
\hline 31 & - & 458.36 & 452.70 & -- & 446.61 & -- & 445.01 & 444.40 & - \\
\hline MEAN & $\cdots$ & 459.63 & 456.24 & 449.28 & 446.84 & 446.93 & 445.59 & 444.86 & 444.66 \\
\hline MAXIMUM & $\cdots$ & 460.72 & 458.79 & 452.27 & 447.51 & 447.85 & 446.42 & 445.61 & 444.89 \\
\hline MNIMUM & -- & 458.36 & 452.70 & 447.70 & 446.16 & 446.27 & 444.88 & 444.40 & 444.41 \\
\hline
\end{tabular}


Table 5. Daily mean water-level altitudes for piezometer WSQ-S19

[Station number 383912090450401; latitude 383912; longitude 0904504; piezometer depth 22.3 feet; altitudes are in feet above sea level; --, no data]

\begin{tabular}{|c|c|c|c|c|c|c|c|c|c|c|}
\hline \multirow[b]{2}{*}{ Day } & \multicolumn{10}{|c|}{1995} \\
\hline & Feb & Mar & Apr & May & June & July & Aug & Sept & Oct & Nov \\
\hline 1 & -- & 445.10 & 445.19 & 448.62 & -- & -- & 456.40 & -- & 445.87 & 446.12 \\
\hline 2 & -- & 444.86 & 445.05 & 449.19 & -- & -- & 456.67 & -- & 445.89 & 446.20 \\
\hline 3 & - & 444.77 & 444.90 & 449.69 & -- & -- & 456.59 & - & 445.97 & 446.24 \\
\hline 4 & 446.56 & 444.63 & 444.80 & 450.02 & -- & - & 456.61 & -- & 445.94 & 446.30 \\
\hline 5 & 446.73 & 444.55 & 444.81 & 450.31 & - & -- & 456.66 & - & 445.96 & 446.43 \\
\hline 6 & 446.84 & 444.48 & .444 .70 & 450.65 & -- & .. & 456.80 & -- & 445.85 & 446.56 \\
\hline 7 & 446.97 & 444.68 & 444.62 & 450.81 & -- & -. & 458.37 & 448.43 & 445.77 & 446.42 \\
\hline 8 & 446.98 & 444.78 & 444.42 & 451.11 & -- & - & 457.87 & 448.39 & 445.70 & 446.54 \\
\hline 9 & 447.05 & 444.78 & 444.38 & 451.82 & -- & -- & 457.08 & 448.20 & 445.56 & 446.69 \\
\hline 10 & 447.07 & 444.84 & 444.31 & 452.53 & -- & - & 456.48 & 447.99 & 445.51 & 446.76 \\
\hline 11 & 446.99 & 444.82 & 444.36 & 453.33 & -- & - & 455.93 & 447.62 & 445.56 & 446.72 \\
\hline 12 & 446.91 & 444.71 & 444.30 & 454.23 & - & -- & 455.43 & 447.58 & 445.57 & 446.79 \\
\hline 13 & 446.78 & -- & 444.56 & 454.89 & -- & -- & 455.18 & 447.42 & 445.55 & 446.81 \\
\hline 14 & 446.69 & 444.68 & 444.90 & 455.06 & -- & - & 454.59 & 447.13 & 445.58 & 446.81 \\
\hline 15 & 446.42 & 444.65 & 445.04 & 455.33 & -- & - & 454.32 & 446.99 & 445.47 & 446.75 \\
\hline 16 & 446.29 & 444.54 & 445.20 & 455.86 & - & -- & -- & 447.09 & 445.29 & 446.83 \\
\hline 17 & 446.24 & 444.41 & 445.38 & - & -- & - & -- & 446.87 & 445.26 & 446.87 \\
\hline 18 & 446.22 & 444.39 & 445.44 & -- &.- & - & -- & 446.71 & 446.67 & 446.24 \\
\hline 19 & 446.12 & 444.49 & 445.64 & - &.- & -- & -- & 446.82 & 445.17 & 445.94 \\
\hline 20 & 446.05 & 444.95 & 446.07 & -- & -- & - & - & 446.75 & 445.22 & 445.80 \\
\hline 21 & 445.94 & 445.09 & 446.43 & -- & - & 460.06 & -- & 446.69 & 445.24 & 445.78 \\
\hline 22 & 445.92 & -- & 446.58 & - & -- & 459.85 & 453.87 & 446.64 & 445.21 & -- \\
\hline 23 & 445.79 & - & 446.87 & - & - & 459.66 & 453.64 & 446.56 & 445.11 & -. \\
\hline 24 & 445.69 & -- & 447.02 & - & -- & 459.52 & -- & 446.43 & 445.04 & -- \\
\hline 25 & 445.68 & $\cdots$ & 447.14 & - & -- & 458.68 & -- & 446.26 & 445.12 & -- \\
\hline 26 & 445.59 & -- & 447.40 & -- & - & 458.47 & -- & 446.16 & 445.19 & -- \\
\hline 27 & 445.53 & -- & 447.42 & - & -- & 458.15 & -- & 446.01 & 445.21 & -- \\
\hline 28 & 445.44 & - & 447.64 & - & -. & 457.57 & - & 445.97 & 445.16 & -- \\
\hline 29 & - & $\ldots$ & 447.78 & - & -- & 457.21 & -- & 445.98 & 445.22 & -- \\
\hline 30 & -- & - & 448.10 & - & -- & 456.77 & -- & 445.95 & 445.53 & -- \\
\hline 31 & -- & 445.57 & - &.- & -- & 456.33 & - & - & 445.92 & -- \\
\hline MEAN & 446.34 & 444.75 & 445.68 & 452.09 & -- & 458.39 & 456.03 & 446.94 & 445.48 & 446.46 \\
\hline MAXIMUM & 447.07 & 445.57 & 448.10 & 455.86 & - & 460.06 & 458.37 & 448.43 & 445.97 & 446.87 \\
\hline MINIMUM & 445.44 & 444.39 & 444.30 & 448.62 & - & 456.33 & 453.64 & 445.95 & 445.04 & 445.78 \\
\hline
\end{tabular}


Table 6. Daily mean water-level altitudes for plezometer WSQ-S25

[Station number 383925090450901; latitude 383925; longitude 0904509; piezometer depth 23.0 feet; altitudes are in feet above sea level; $-\cdots$, no data]

\begin{tabular}{|c|c|c|c|c|c|c|c|c|}
\hline \multirow[b]{2}{*}{ Day } & \multicolumn{3}{|c|}{1994} & \multicolumn{5}{|c|}{1995} \\
\hline & Oct & Nov & Dec & Jan & Fob & Mar & Apr & May \\
\hline 1 & -- &.- & 448.20 & 447.54 & 449.38 & 448.43 & 448.92 & 450.69 \\
\hline 2 & -2 & -- & 448.23 & 447.48 & 449.30 & 448.41 & 448.84 & 451.49 \\
\hline 3 & -- & - & 448.16 & 447.41 & 449.35 & 448.41 & 448.78 & 452.17 \\
\hline 4 & -- & -- & 448.09 & 447.33 & 449.63 & 448.37 & 448.59 & 452.76 \\
\hline 5 & -- &.- & 448.04 & 447.36 & 449.82 & 448.35 & 448.62 & 453.23 \\
\hline 6 & -- & $\therefore$ & 448.02 & 447.50 & 449.90 & 448.23 & 448.64 & 453.59 \\
\hline 7 & -- & - & 447.96 & 447.19 & 449.89 & 449.31 & 448.55 & 453.82 \\
\hline 8 & - & - & 447.91 & 447.13 & 449.74 & 450.27 & 448.53 & 454.07 \\
\hline 9 & -- & -- & 447.93 & 447.06 & 449.84 & 450.11 & 448.40 & 454.37 \\
\hline 10 & - & -- & 447.90 & 447.08 & 449.81 & 449.93 & 448.28 & 454.55 \\
\hline 11 & -- & - & 447.83 & 447.11 & 449.60 & 449.74 & 448.23 & 454.70 \\
\hline 12 & -. & - & 447.86 & 447.04 & 449.51 & 449.56 & 448.15 & 454.95 \\
\hline 13 & -- & - & 447.82 & 447.12 & 449.50 & 449.37 & 448.11 & 455.22 \\
\hline 14 & -- & - & 447.78 & 448.78 & 449.50 & 449.20 & 448.27 & 455.26 \\
\hline 15 & - & - & 447.75 & 449.16 & 449.47 & 449.10 & 448.37 & 455.39 \\
\hline 16 & -- & 447.12 & 447.78 & 449.08 & 449.18 & 448.98 & 448.38 & 455.62 \\
\hline 17 &.- & 447.18 & 447.69 & 448.98 & 449.10 & 448.86 & 448.40 & 456.42 \\
\hline 18 & -- & 447.07 & 447.61 & 448.82 & 449.12 & 448.79 & 448.54 & -- \\
\hline 19 & -- & 447.02 & 447.60 & 449.23 & 449.09 & 448.78 & 448.39 & -- \\
\hline 20 & -- & 447.24 & 447.61 & 449.53 & 449.05 & 448.74 & 448.81 & -- \\
\hline 21 & -- & 447.30 & 447.56 & 449.55 & 448.88 & 448.68 & 449.10 & -- \\
\hline 22 & -- & 447.40 & 447.72 & 449.49 & 448.91 & 448.71 & 449.26 & -- \\
\hline 23 & -- & 447.70 & 447.90 & 449.34 & 448.81 & 448.63 & 449.52 & -- \\
\hline 24 & -- & 447.97 & 447.97 & 449.20 & 448.63 & 448.55 & 449.64 & -- \\
\hline 25 & - & 448.02 & 447.99 & 449.13 & 448.75 & 448.55 & 449.74 & -- \\
\hline 26 & - & 448.11 & 447.97 & 449.07 & 448.68 & 448.59 & 449.90 & -- \\
\hline 27 & -. & 448.33 & 447.93 & 449.18 & 448.61 & 448.68 & 449.91 & -. \\
\hline 28 & - & 448.11 & 447.83 & 449.12 & 448.49 & 448.76 & 449.96 & -- \\
\hline 29 & -. & 448.07 & 447.74 & 449.06 & - & 448.82 & 450.08 & -- \\
\hline 30 & -- & 448.11 & 447.72 & 449.21 & -- & 448.87 & 450.22 & -- \\
\hline 31 & $\therefore$ & -- & 447.67 & 449.37 & -- & 448.90 & - & -- \\
\hline MEAN & -. & 447.65 & 447.86 & 448.38 & 449.27 & 448.93 & 448.90 & 454.02 \\
\hline MAXIMUM & - & 448.33 & 448.23 & 449.55 & 449.90 & 450.27 & 450.22 & 456.42 \\
\hline MINIMUM & - & 447.02 & 447.56 & 447.04 & 448.49 & 448.23 & 448.11 & 450.69 \\
\hline
\end{tabular}


Table 6. Daily mean water-level altitudes for piezometer WSQ-S25-Continued

\begin{tabular}{|c|c|c|c|c|c|c|c|c|c|}
\hline \multirow[b]{2}{*}{ Day } & \multicolumn{7}{|c|}{1995} & \multicolumn{2}{|c|}{1996} \\
\hline & June & July & Aug & Sept & Oct & Nov & Dec & Jan & Feb \\
\hline 1 & - & -. & 458.83 & 453.60 & 450.19 & 449.11 & 448.53 & 447.65 & 447.42 \\
\hline 2 & -- & .. & 458.79 & 453.34 & 450.13 & 449.09 & 448.50 & 447.62 & 447.34 \\
\hline 3 & -. & -. & 458.65 & 453.11 & 450.12 & 449.01 & 448.45 & 447.59 & 447.33 \\
\hline 4 & -- & -. & 458.49 & 452.92 & 450.13 & 449.01 & 448.15 & 447.59 & 447.33 \\
\hline 5 & -. & -. & 458.35 & 452.71 & 450.01 & 449.09 & 448.25 & 447.50 & 447.38 \\
\hline 6 & -- & $\therefore$ & 458.21 & 452.56 & 449.88 & 449.20 & 448.29 & 447.51 & 447.39 \\
\hline 7 & -- & -- & 458.67 & 452.32 & 449.77 & 449.14 & 448.29 & 447.52 & 447.44 \\
\hline 8 & -. & .. & 458.67 & 452.11 & 449.75 & 448.98 & 448.28 & 447.55 & 447.38 \\
\hline 9 & -. & .. & 458.48 & 451.98 & 449.73 & 449.15 & 448.14 & 447.53 & 447.27 \\
\hline 10 & -- & .. & 458.25 & 451.84 & 449.60 & 449.25 & 448.11 & 447.40 & 447.28 \\
\hline 11 & -. & .- & 458.06 & 451.73 & 449.59 & 449.04 & 448.12 & 447.46 & 447.15 \\
\hline 12 & -- & -- & 457.82 & 451.63 & 449.58 & 449.11 & 448.10 & 447.36 & 447.09 \\
\hline 13 & -- & -- & 457.62 & 451.49 & 449.57 & 449.14 & 448.08 & 447.37 & 447.23 \\
\hline 14 & - & -- & 457.34 & 451.39 & 449.48 & 449.07 & 447.97 & 447.40 & 447.22 \\
\hline 15 & -- & -- & 457.03 & 451.35 & 449.46 & 449.10 & 447.86 & 447.32 & 447.09 \\
\hline 16 & -- & -- & 456.82 & 451.35 & 449.35 & 449.10 & 447.83 & 447.49 & 447.03 \\
\hline 17 & -- & -- & 456.70 & 451.29 & 449.32 & 449.12 & 447.82 & 447.51 & 447.18 \\
\hline 18 & -- & .- & 456.52 & 451.16 & 449.27 & 449.06 & 447.82 & 447.52 & 447.14 \\
\hline 19 & - & .. & 456.33 & 451.12 & 449.23 & 448.99 & 447.87 & 447.55 & 447.20 \\
\hline 20 & -. & -. & 456.15 & 451.01 & 449.18 & 448.90 & 447.91 & 447.69 & 447.14 \\
\hline 21 & -- & .. & 455.95 & 450.92 & 449.17 & 448.86 & 448.02 & 447.70 & 447.05 \\
\hline 22 & -- & -- & 455.75 & 450.86 & 449.14 & 448.87 & 448.01 & 447.69 & 447.10 \\
\hline 23 & .- & .. & 455.55 & 450.82 & 449.08 & 448.79 & 447.97 & 447.75 & 447.16 \\
\hline 24 & -- & -. & 455.35 & 450.77 & 448.95 & 448.71 & 447.96 & 447.84 & 446.99 \\
\hline 25 & -- & -. & 455.11 & 450.70 & 448.97 & 448.78 & 447.91 & 447.95 & 447.07 \\
\hline 26 & -- & -- & 454.89 & 450.59 & 449.08 & 448.84 & 447.88 & 447.99 & 447.12 \\
\hline 27 & -- & .. & 454.67 & 450.48 & 449.09 & 448.79 & 447.78 & 447.71 & .. \\
\hline 28 & -- & 460.01 & 454.36 & 450.40 & 448.91 & 448.54 & 447.71 & 447.72 & -- \\
\hline 29 & -- & 459.59 & 454.15 & 450.36 & 448.87 & 448.56 & 447.71 & 447.66 & -. \\
\hline 30 & -- & 459.29 & 454.00 & 450.30 & 448.93 & 448.64 & 447.74 & 447.54 & -- \\
\hline 31 & -- & 459.04 & 453.81 & -. & 449.01 & -- & 447.75 & 447.44 & - \\
\hline MEAN & -- & 459.48 & 456.75 & 451.54 & 449.44 & 448.97 & 448.03 & 447.58 & 447.21 \\
\hline MAXIMUM & -- & 460.01 & 458.83 & 453.60 & 450.19 & 449.25 & 448.53 & 447.99 & 447.44 \\
\hline MINIMUM & - & 459.04 & 453.81 & 450.30 & 448.87 & 448.54 & 447.71 & 447.32 & 446.99 \\
\hline
\end{tabular}


Table 7. Daily mean water-level altitudes for piezometer WSQ-B4

[Station number 383925090450201; latitude 383925; longitude 0904502; piezometer depth 66.0 feet; altitudes are in feet above sea level; $\cdots$, no data]

\begin{tabular}{|c|c|c|c|c|c|c|c|}
\hline \multirow[b]{2}{*}{ Day } & \multicolumn{3}{|c|}{1994} & \multicolumn{4}{|c|}{1995} \\
\hline & Oct & Nov & Dec & Jan & Feb & Mar & Apr \\
\hline 1 & $\cdots$ & $-\cdot$ & 445.33 & 443.93 & 445.82 & 445.08 & 445.21 \\
\hline 2 & - &.- & 445.31 & 443.88 & 445.82 & 444.95 & 445.12 \\
\hline 3 & - & - & 445.25 & 443.80 & 445.91 & 444.90 & 445.08 \\
\hline 4 & -- & $\cdots$ & 445.23 & 443.77 & 446.07 & 444.83 & 444.95 \\
\hline 5 & $\therefore$ & $-\therefore$ & 445.19 & 443.78 & 446.19 & 444.77 & 445.02 \\
\hline 6 & -- & -- & 445.22 & 443.82 & 446.31 & 444.70 & 444.99 \\
\hline 7 & -- & -- & 445.14 & 443.61 & 446.39 & 445.10 & 444.94 \\
\hline 8 & -- & -- & 445.13 & 443.55 & 446.38 & 445.37 & 444.88 \\
\hline 9 & -- & - & 445.10 & 443.49 & 446.51 & 445.30 & 444.73 \\
\hline 10 & -- & -- & 445.11 & 443.46 & 446.55 & 445.27 & 444.67 \\
\hline 11 & -- & - & 445.09 & 443.46 & 446.47 & 445.24 & 444.64 \\
\hline 12 & -- & -- & 445.09 & 443.37 & 446.43 & 445.15 & 444.59 \\
\hline 13 & - & -- & 445.00 & 443.48 & 446.40 & 445.04 & 444.66 \\
\hline 14 & -- & - & 444.95 & 444.09 & 446.37 & 444.97 & 444.90 \\
\hline 15 & -- & -- & 444.89 & 444.12 & 446.26 & 444.93 & 445.05 \\
\hline 16 & -- & - & 444.89 & 444.27 & 446.05 & 444.83 & 445.10 \\
\hline 17 & -- & -- & 444.77 & 444.38 & 445.97 & 444.72 & 445.22 \\
\hline 18 & -- & -- & 444.65 & 444.46 & 445.95 & 444.67 & 445.34 \\
\hline 19 & -- & 443.59 & 444.61 & 444.82 & 445.88 & 444.71 & 445.38 \\
\hline 20 & $-\cdot$ & 443.71 & 444.53 & 444.95 & 445.82 & 444.77 & 445.78 \\
\hline 21 & -- & 443.80 & 444.44 & 445.04 & 445.70 & 444.86 & 446.05 \\
\hline 22 & - & 443.98 & 444.49 & 445.11 & 445.69 & 444.96 & 446.22 \\
\hline 23 & -- & 444.22 & 444.49 & 445.15 & 445.58 & 444.96 & 446.45 \\
\hline 24 & -- & 444.48 & 444.47 & 445.17 & 445.45 & 444.93 & 446.64 \\
\hline 25 & -- & 444.66 & 444.42 & 445.22 & 445.48 & 444.93 & 446.83 \\
\hline 26 & -- & 444.86 & 444.35 & 445.25 & 445.39 & 445.01 & 447.04 \\
\hline 27 & -- & 445.08 & 444.26 & 445.36 & 445.31 & 445.06 & 447.13 \\
\hline 28 & -- & 445.10 & 444.18 & 445.41 & 445.20 & 445.10 & 447.28 \\
\hline 29 & $\because$ & 445.17 & 444.13 & 445.43 & -- & 445.15 & 447.47 \\
\hline 30 & -- & 445.29 & 444.08 & 445.57 & - & 445.20 & 447.72 \\
\hline 31 & - & - & 444.03 & 445.74 & -- & 445.25 & -- \\
\hline MEAN & -- & 444.49 & 444.77 & 444.42 & 445.98 & 444.99 & 445.64 \\
\hline MAXIMUM & $\cdots$ & 445.29 & 445.33 & 445.74 & 446.55 & 445.37 & 447.72 \\
\hline MINIMUM & - & 443.59 & 444.03 & 443.37 & 445.20 & 444.67 & 444.59 \\
\hline
\end{tabular}


Table 7. Daily mean water-level altitudes for piezometer WSQ-B4-Continued

\begin{tabular}{|c|c|c|c|c|c|c|c|}
\hline \multirow[b]{2}{*}{ Day } & \multicolumn{7}{|c|}{1995} \\
\hline & May & June & July & Aug & Sept & Oct & Nov \\
\hline 1 & 448.14 & - & -. & 458.18 & - & 446.32 & 445.78 \\
\hline 2 & 448.68 & - & - & 458.17 & -- & 446.28 & 445.81 \\
\hline 3 & 449.14 & - & - & 458.08 & $\cdots$ & 446.31 & 445.78 \\
\hline 4 & 449.52 & - & -- & 458.01 & -- & 446.28 & 445.81 \\
\hline 5 & 449.91 & - & - & 457.92 & -. & 446.26 & 445.91 \\
\hline 6 & 450.29 & - & -- & 457.82 & -. & 446.17 & 446.01 \\
\hline 7 & 450.63 & - & - & 458.48 & 448.93 & 446.09 & 445.97 \\
\hline 8 & 451.06 & - & - & 458.37 & 448.81 & 446.09 & 445.87 \\
\hline 9 & 451.62 & - & -- & 458.06 & 448.68 & 446.02 & 446.10 \\
\hline 10 & 452.34 & - & -- & - & .448 .48 & 445.92 & 446.16 \\
\hline 11 & 453.05 & - & -- & -- & 448.27 & 445.93 & 446.10 \\
\hline 12 & 453.81 & - & - & -- & 448.16 & 445.92 & 446.16 \\
\hline 13 & 454.47 & - & - & $\because$ & 448.01 & 445.92 & 446.18 \\
\hline 14 & 454.79 & - & -- & -- & 447.80 & 445.85 & 446.16 \\
\hline 15 & 455.19 & - & - & -- & 447.66 & 445.82 & 446.17 \\
\hline 16 & 455.65 & - & -- & $\cdots$ & 447.61 & 445.65 & 446.20 \\
\hline 17 & 457.27 & - & -- & $\cdots$ & 447.50 & 445.64 & 446.23 \\
\hline 18 & -. & - & - & - & 447.31 & 445.53 & 446.11 \\
\hline 19 & -- & - & -- & -- & 447.26 & 445.51 & 446.00 \\
\hline 20 & -- & -- & -- & -- & 447.16 & 445.42 & 445.91 \\
\hline 21 & $-\cdot$ & $\cdots$ & 460.74 & -- & 447.11 & 445.47 & 445.91 \\
\hline 22 & - & - & 460.57 & 454.52 & 447.05 & 445.44 & -- \\
\hline 23 & -- & - & 460.38 & 454.20 & 447.00 & 445.39 & $\cdots$ \\
\hline 24 & - & -- & 460.21 & 453.92 & 446.97 & 445.26 &.- \\
\hline 25 & -- & -- & 459.95 & 453.60 & 446.86 & 445.29 & -- \\
\hline 26 & $\ldots$ & -- & 459.67 & 453.28 & 446.76 & 445.36 & -- \\
\hline 27 & -. & $\cdots$ & 459.51 & 452.94 & 446.63 & 445.34 & -- \\
\hline 28 & -- & - & 459.17 & 452.15 & 446.54 & 445.28 & -- \\
\hline 29 & -- & - & 458.93 & 452.02 & 446.51 & 445.36 & -- \\
\hline 30 & - & - & 458.66 & 451.79 & 446.46 & 445.49 & -- \\
\hline 31 & -- & $\cdots$ & 458.38 & 451.72 & - & 445.65 & -- \\
\hline MEAN & 452.09 & - & 459.65 & 455.43 & 447.48 & 445.75 & 446.02 \\
\hline MAXIMUM & 457.27 & - & 460.74 & 458.48 & 448.93 & 446.32 & 446.23 \\
\hline MINIMUM & 448.14 & -- & 458.38 & 451.72 & 446.46 & 445.26 & 445.78 \\
\hline
\end{tabular}


Table 8. Daily mean water-level altitudes for monitoring well MW-1019

[Station number 383921090451001 ; latitude 383921; longitude 0904510; well depth 68.0 feet; altitudes are in feet above sea level; --, no data]

\begin{tabular}{|c|c|c|c|c|c|c|}
\hline \multirow[b]{2}{*}{ Day } & \multicolumn{6}{|c|}{1995} \\
\hline & Feb & Mar & Apr & May & June & July \\
\hline 1 & -- & 445.92 & 446.16 & 449.08 & - & -- \\
\hline 2 & - & 445.80 & 446.05 & 449.73 & -- & - \\
\hline 3 & -- & 445.74 & 445.97 & 450.21 & -- & -- \\
\hline 4 & 447.00 & 445.67 & 445.82 & 450.60 & -- & - \\
\hline 5 & 447.00 & 445.59 & 445.87 & 450.94 & -- & - \\
\hline 6 & 447.00 & 445.50 & 445.80 & 451.30 & - & - \\
\hline 7 & 447.00 & 446.07 & 445.72 & 451.57 & - & -- \\
\hline 8 & 447.01 & 446.39 & 445.63 & 451.90 & -- & - \\
\hline 9 & 447.29 & 446.32 & 445.46 & 452.45 & - & - \\
\hline 10 & 447.55 & 446.29 & 445.40 & 453.10 & - & - \\
\hline 11 & 447.42 & 446.23 & 445.39 & 453.70 & - & -- \\
\hline 12 & 447.34 & 446.11 & 445.37 & 454.40 & -. & $\because$ \\
\hline 13 & 447.26 & 445.96 & 445.53 & 455.05 & -- & -- \\
\hline 14 & 447.22 & 445.83 & 445.86 & 455.22 & - & - \\
\hline 15 & 447.09 & 445.70 & 446.02 & 455.47 & $\cdots$ & - \\
\hline 16 & 446.90 & 445.59 & 446.07 & 455.84 & -- & -- \\
\hline 17 & 446.82 & 445.45 & 446.17 & 457.68 & - & - \\
\hline 18 & 446.82 & 445.43 & 446.29 & -- & -. & -. \\
\hline 19 & 446.75 & 445.52 & 446.38 & -- & -- & -- \\
\hline 20 & 446.68 & 445.64 & 446.86 & - & $\cdots$ & - \\
\hline 21 & 446.51 & 445.73 & 447.13 & -- & - & 460.11 \\
\hline 22 & 446.50 & 445.82 & 447.30 & - & -- & 459.92 \\
\hline 23 & 446.37 & 445.79 & 447.54 & -- & -- & 459.78 \\
\hline 24 & 446.23 & 445.74 & 447.69 & - & - & 459.62 \\
\hline 25 & 446.28 & 445.76 & - & -- & -- & 459.26 \\
\hline 26 & 446.20 & 445.84 & -- & - & -- & 459.04 \\
\hline 27 & 446.14 & 445.93 & - & - & - & 458.83 \\
\hline 28 & 446.03 & 445.99 & 448.15 & - & -- & 458.43 \\
\hline 29 & - & 446.04 & 448.21 & -. & - & 458.13 \\
\hline 30 & -- & 446.11 & 448.57 & - & -- & 457.84 \\
\hline 31 & - & 446.21 & $-\cdot$ & - & -- & 457.54 \\
\hline MEAN & 446.82 & 445.86 & 446.39 & 452.84 & - & 458.95 \\
\hline MAXIMUM & 447.55 & 446.39 & 448.57 & 457.68 & -- & 460.11 \\
\hline MINIMUM & 446.03 & 445.43 & 445.37 & 449.08 &.- & 457.54 \\
\hline
\end{tabular}


Table 8. Daily mean water-tevel altitudes for monitoring well MW-1019-Continued

\begin{tabular}{|c|c|c|c|c|c|c|c|}
\hline \multirow[b]{2}{*}{ Day } & \multicolumn{5}{|c|}{1995} & \multicolumn{2}{|c|}{1996} \\
\hline & Aug & Sept & Oct & Nov & Dec & Jan & Feb \\
\hline 1 & 457.42 & - & 447.26 & 446.83 & 446.45 & 444.71 & 444.09 \\
\hline 2 & 457.46 & - & 447.22 & 446.87 & 446.38 & 444.70 & 444.20 \\
\hline 3 & 457.36 & - & 447.26 & 446.86 & 446.24 & 444.63 & 444.30 \\
\hline 4 & 457.33 & -- & 447.25 & 446.89 & 446.18 & 444.59 & 444.29 \\
\hline 5 & $\begin{array}{c}457.35 \\
:\end{array}$ & - & 447.24 & 447.01 & 446.17 & 444.50 & 444.42 \\
\hline 6 & 457.42 & - & 447.14 & 447.14 & 446.10 & 444.50 & 444.46 \\
\hline 7 & 458.62 & 449.76 & 447.04 & 447.06 & 446.07 & 444.48 & 444.53 \\
\hline 8 & 458.33 & 449.66 & 447.04 & 446.80 & 446.07 & 444.44 & 444.49 \\
\hline 9 & 457.76 & 449.53 & 446.96 & 447.22 & 445.93 & 444.41 & 444.44 \\
\hline 10 & 457.24 & 449.35 & 446.85 & 447.31 & 445.92 & 444.32 & 444.45 \\
\hline 11 & 456.86 & 449.12 & 446.88 & 447.20 & 445.92 & 444.34 & 444.36 \\
\hline 12 & 456.50 & 449.03 & 446.87 & 447.27 & 445.81 & 444.24 & 444.33 \\
\hline 13 & 456.29 & 448.88 & 446.88 & 447.30 & 445.82 & 444.27 & 444.44 \\
\hline 14 & 455.85 & 448.67 & 446.82 & 447.27 & 445.69 & 444.24 & 444.46 \\
\hline 15 & 455.55 & 448.55 & 446.80 & 447.27 & 445.60 & 444.14 & 444.44 \\
\hline 16 & 455.38 & 448.54 & 446.64 & 447.28 & 445.53 & 444.26 & 444.47 \\
\hline 17 & 455.52 & 448.42 & 446.64 & 447.33 & 445.44 & 444.20 & 444.62 \\
\hline 18 & 455.38 & 448.25 & 446.54 & 447.13 & 445.37 & 444.15 & 444.63 \\
\hline 19 & 455.28 & 448.22 & 446.53 & 446.93 & 445.31 & 444.08 & 444.69 \\
\hline 20 & 455.14 & 448.13 & 446.48 & 446.79 & 445.24 & 444.19 & 444.66 \\
\hline 21 & 454.82 & 448.06 & 446.51 & 446.77 & 445.22 & 444.17 & 444.62 \\
\hline 22 & 454.48 & 448.00 & 446.48 & 446.79 & 445.11 & 444.18 & 444.69 \\
\hline 23 & 454.23 & 447.95 & 446.42 & 446.65 & 445.07 & 444.25 & 444.72 \\
\hline 24 & 453.96 & 447.92 & 446.28 & 446.64 & 445.06 & 444.27 & 444.63 \\
\hline 25 & 453.68 & 447.81 & 446.35 & 446.73 & 444.99 & 444.38 & 444.69 \\
\hline 26 & 453.40 & 447.70 & 446.44 & 446.78 & 444.99 & 444.42 & 444.72 \\
\hline 27 & 453.08 & 447.55 & 446.41 & 446.66 & 444.88 & 444.21 & 444.72 \\
\hline 28 & 452.36 & 447.45 & 446.30 & 446.50 & 444.82 & 444.28 & -- \\
\hline 29 & 452.39 & 447.43 & 446.33 & 446.52 & 444.81 & 444.16 & - \\
\hline 30 & 452.24 & 447.38 & 446.46 & 446.57 & 444.83 & 444.05 & - \\
\hline 31 & -- & -- & 446.67 & -- & 444.80 & 444.01 & -- \\
\hline MEAN & 455.62 & 448.39 & 446.74 & 446.95 & 445.54 & 444.32 & 444.50 \\
\hline MAXIMUM & 458.62 & 449.76 & 447.26 & 447.33 & 446.45 & 444.71 & 444.72 \\
\hline MINIMUM & 452.24 & 447.38 & 446.28 & 446.50 & 444.80 & 444.01 & 444.09 \\
\hline
\end{tabular}


Table 9. Daily mean stage for Femme Osage Slough (staff gage WSQ-SG5)

[Station number 383925090450601; latitude 383925; longitude 0904506; datum 470 feet; stage is in feet above sea level; --, no data]

\begin{tabular}{|c|c|c|c|c|c|c|c|}
\hline \multirow[b]{2}{*}{ Day } & \multicolumn{7}{|c|}{1995} \\
\hline & Jan & Feb & Mar & Apr & May & June & July \\
\hline 1 & - & 450.10 & 450.06 & 450.19 & 451.90 & $\cdots$ & $\cdots$ \\
\hline 2 & -- & 450.10 & 450.04 & 450.19 & 452.80 & - & -- \\
\hline 3 & -- & 450.16 & 450.03 & 450.17 & 453.68 & -- & - \\
\hline 4 & - & 450.20 & 450.03 & 450.16 & 454.30 & $-\cdot$ & - \\
\hline 5 & $\therefore$ & 450.20 & 450.05 & 450.15 & 454.68 & -- & -- \\
\hline 6 & - & 450.20 & 450.18 & 450.13 & 454.83 & -- & -- \\
\hline 7 & -- & 450.20 & 450.35 & 450.13 & 454.92 & - & -- \\
\hline 8 & - & 450.20 & 450.38 & 450.11 & 455.02 & - & -- \\
\hline 9 & -- & 450.20 & 450.38 & 450.09 & 455.16 & - & - \\
\hline 10 & -- & 450.20 & 450.38 & 450.07 & 455.12 & - & - \\
\hline 11 & -- & 450.19 & 450.38 & 450.05 & 455.08 & - & -- \\
\hline 12 & -- & 450.19 & 450.38 & 450.05 & 455.06 & -- & $\cdots$ \\
\hline 13 & - & 450.18 & 450.38 & 450.04 & 455.10 & - & -- \\
\hline 14 & -- & 450.16 & 450.37 & 450.03 & 455.12 & -- & $\because$ \\
\hline 15 & -- & 450.16 & 450.36 & 450.00 & 455.14 & - & $\cdots$ \\
\hline 16 & -- & 450.14 & 450.36 & 449.98 & 455.20 & -- & $\cdots$ \\
\hline 17 & $\cdots$ & 450.14 & 450.35 & 449.97 & 456.08 & -- & -- \\
\hline 18 & - & 450.13 & 450.32 & 449.97 & -- & -- & $\cdots$ \\
\hline 19 & -- & 450.09 & 450.29 & 449.98 & -- & - & -- \\
\hline 20 & $\because$ & 450.09 & 450.29 & 450.43 & - & -- & - \\
\hline 21 & -- & 450.09 & 450.29 & 450.77 & -- & -- & -- \\
\hline 22 & -- & 450.09 & 450.26 & 450.94 & -- & -- & -- \\
\hline 23 & -- & 450.09 & 450.19 & 451.00 & $\cdots$ & -- & $\cdots$ \\
\hline 24 & $\therefore$ & 450.08 & 450.19 & 451.02 & - & -- & - \\
\hline 25 & -- & 450.06 & 450.19 & 451.00 & - & - & - \\
\hline 26 & -- & 450.06 & 450.20 & 450.99 & - & -- & - \\
\hline 27 & -- & 450.09 & 450.26 & 450.98 & - & -- & -- \\
\hline 28 & 450.10 & 450.08 & 450.24 & 450.98 & - & -- & -- \\
\hline 29 & 450.10 & - & 450.23 & 450.98 & - & - & - \\
\hline 30 & 450.10 & -- & -- & 451.17 & - & - & - \\
\hline 31 & 450.10 & -- & 450.19 & -- & -- & -- & -- \\
\hline MEAN & 450.10 & 450.14 & 450.25 & 450.39 & 454.66 & - & -. \\
\hline MAXIMUM & 450.10 & 450.20 & 450.38 & 451.17 & 456.08 & - & -- \\
\hline MINIMUM & .450 .10 & 450.06 & 450.03 & 449.97 & 451.90 & - & - \\
\hline
\end{tabular}


Table 9. Daily mean stage for Femme Osage Slough (staff gage WSQ-SG5)-Continued

\begin{tabular}{|c|c|c|c|c|c|c|c|}
\hline \multirow[b]{2}{*}{ Day } & \multicolumn{5}{|c|}{1995} & \multicolumn{2}{|c|}{1996} \\
\hline & Aug & Sept & Oct & Nov & Dec & Jan & Feb \\
\hline 1 & - & - & 452.29 & 451.27 & 450.69 & 450.48 & 450.33 \\
\hline 2 & - & - & 452.27 & 451.27 & 450.67 & 450.48 & 450.30 \\
\hline 3 & -- & - & 452.23 & 451.24 & 450.65 & 450.49 & 450.28 \\
\hline 4 & -- & - & 452.14 & 451.19 & 450.63 & 450.49 & 450.26 \\
\hline 5 & -- & - & 452.08 & 451.16 & 450.60 & 450.49 & 450.25 \\
\hline 6 & -- & - & 452.03 & 451.13 & 450.59 & 450.48 & 450.23 \\
\hline 7 & -- & - & 452.01 & 451.11 & 450.58 & 450.47 & 450.22 \\
\hline 8 & - & 453.51 & 451.99 & 451.10 & 450.55 & 450.47 & 450.22 \\
\hline 9 & - & 453.43 & 451.98 & 451.07 & 450.52 & 450.43 & 450.20 \\
\hline 10 & -- & 453.35 & 451.97 & 451.05 & 450.52 & 450.41 & 450.19 \\
\hline 11 & - & 453.26 & 451.97 & 451.06 & 450.50 & 450.40 & 450.17 \\
\hline 12 & -- & 453.17 & 451.96 & 451.05 & 450.47 & 450.38 & 450.17 \\
\hline 13 & - & 453.10 & 451.96 & 451.05 & 450.45 & 450.38 & 450.16 \\
\hline 14 & - & 453.08 & 451.96 & 451.03 & 450.45 & 450.38 & 450.14 \\
\hline 15 & -- & 453.08 & 451.95 & 451.03 & 450.44 & 450.37 & 450.13 \\
\hline 16 & -. & 453.13 & 451.95 & 451.01 & 450.43 & 450.36 & 450.12 \\
\hline 17 & - & 453.11 & 451.95 & 450.99 & 450.42 & 450.34 & 450.10 \\
\hline 18 &.- & 453.05 & 451.95 & 450.97 & 450.41 & 450.38 & 450.09 \\
\hline 19 &.- & 452.98 & 451.95 & 450.95 & 450.59 & 450.40 & 450.09 \\
\hline 20 & -- & 452.92 & 451.95 & 450.92 & 450.63 & 450.40 & 450.08 \\
\hline 21 & -- & 452.85 & 451.95 & 450.88 & 450.63 & 450.40 & 450.07 \\
\hline 22 & $\cdots$ & 452.78 & 451.95 & 450.87 & 450.62 & 450.39 & 450.06 \\
\hline 23 & -- & 452.72 & 451.95 & 450.85 & 450.61 & 450.40 & 450.04 \\
\hline 24 & -- & 452.67 & 451.95 & 450.83 & 450.58 & 450.43 & 450.02 \\
\hline 25 & -- & 452.57 & 451.68 & 450.80 & 450.56 & 450.42 & 450.02 \\
\hline 26 & -- & 452.50 & 451.33 & 450.77 & 450.55 & 450.42 & 450.01 \\
\hline 27 &.- & 452.45 & 451.34 & 450.74 & 450.55 & 450.40 & -- \\
\hline 28 & -- & 452.40 & 451.32 & 450.74 & 450.53 & 450.38 & -. \\
\hline 29 & - & 452.34 & 451.31 & 450.74 & 450.51 & 450.37 & -- \\
\hline 30 & -. & 452.31 & 451.30 & 450.71 & 450.50 & 450.36 & - \\
\hline 31 & -- & - & 451.29 & -- & 450.48 & 450.34 & -- \\
\hline MEAN & - & 452.90 & 451.87 & 450.99 & 450.55 & 450.41 & 450.15 \\
\hline MAXIMUM & -. & 453.51 & 452.29 & 451.27 & 450.69 & 450.49 & 450.33 \\
\hline MINIMUM & -- & 452.31 & 451.29 & 450.71 & 450.41 & 450.34 & 450.01 \\
\hline
\end{tabular}




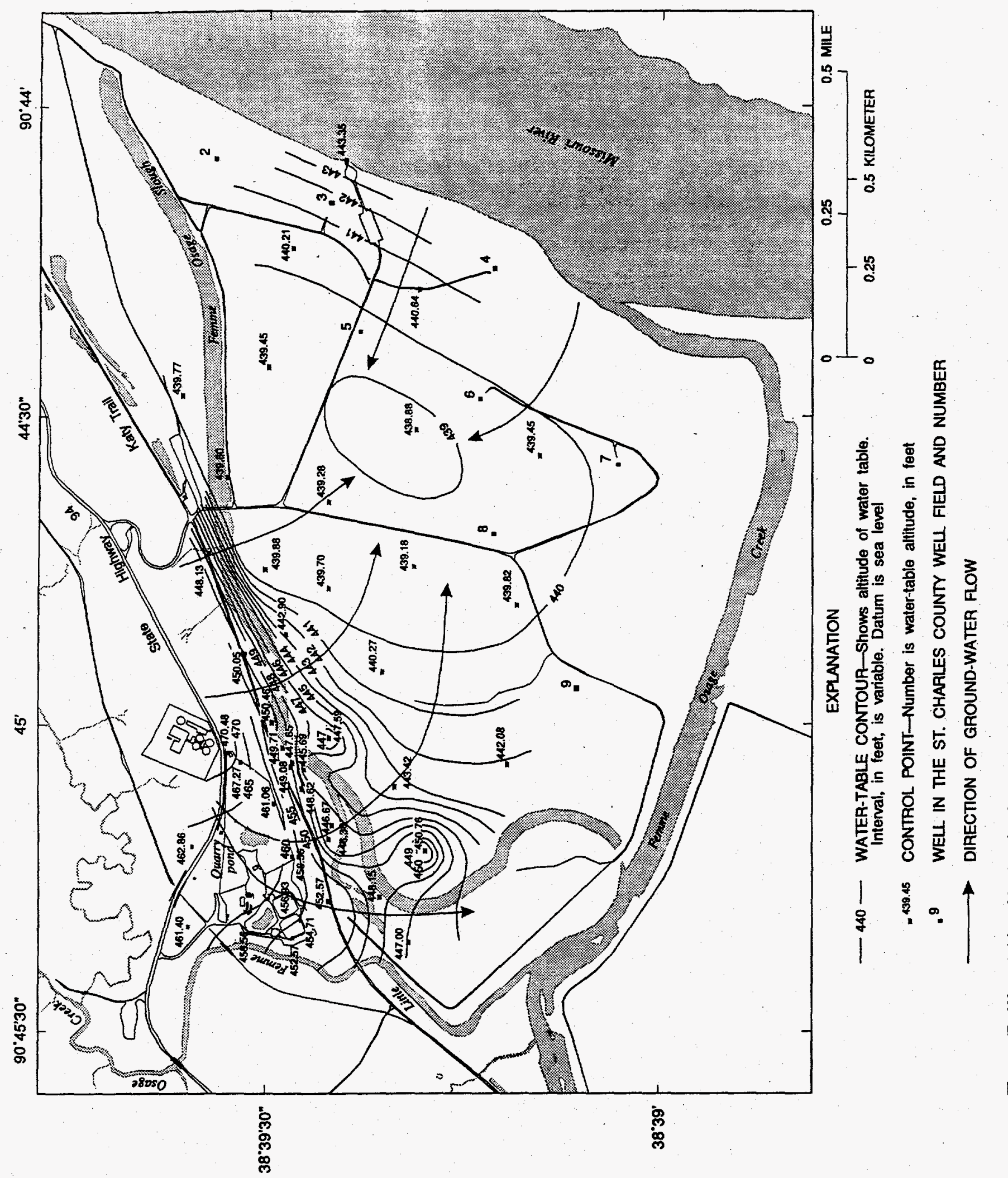

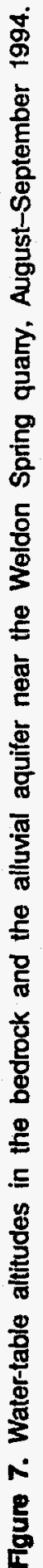




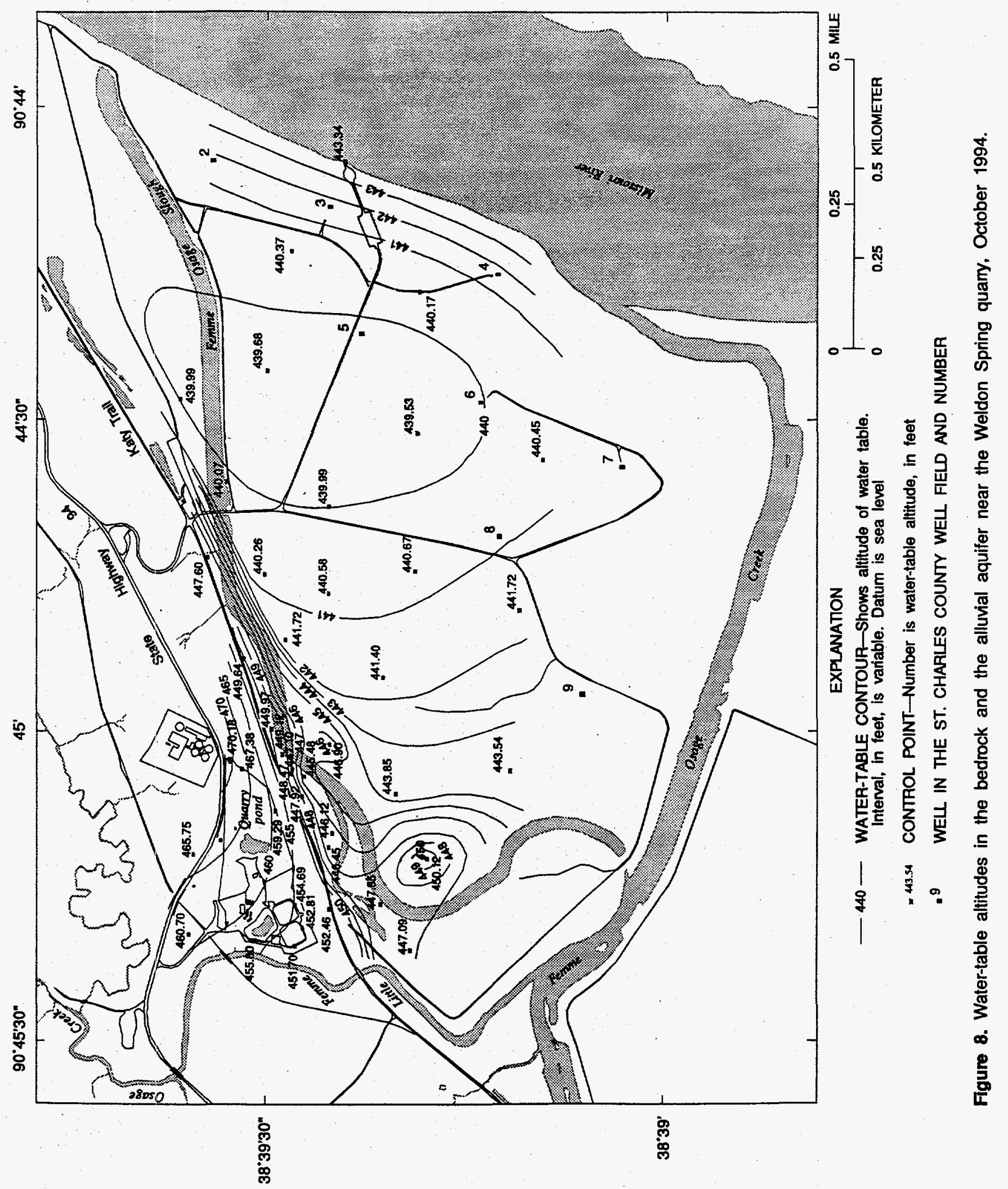




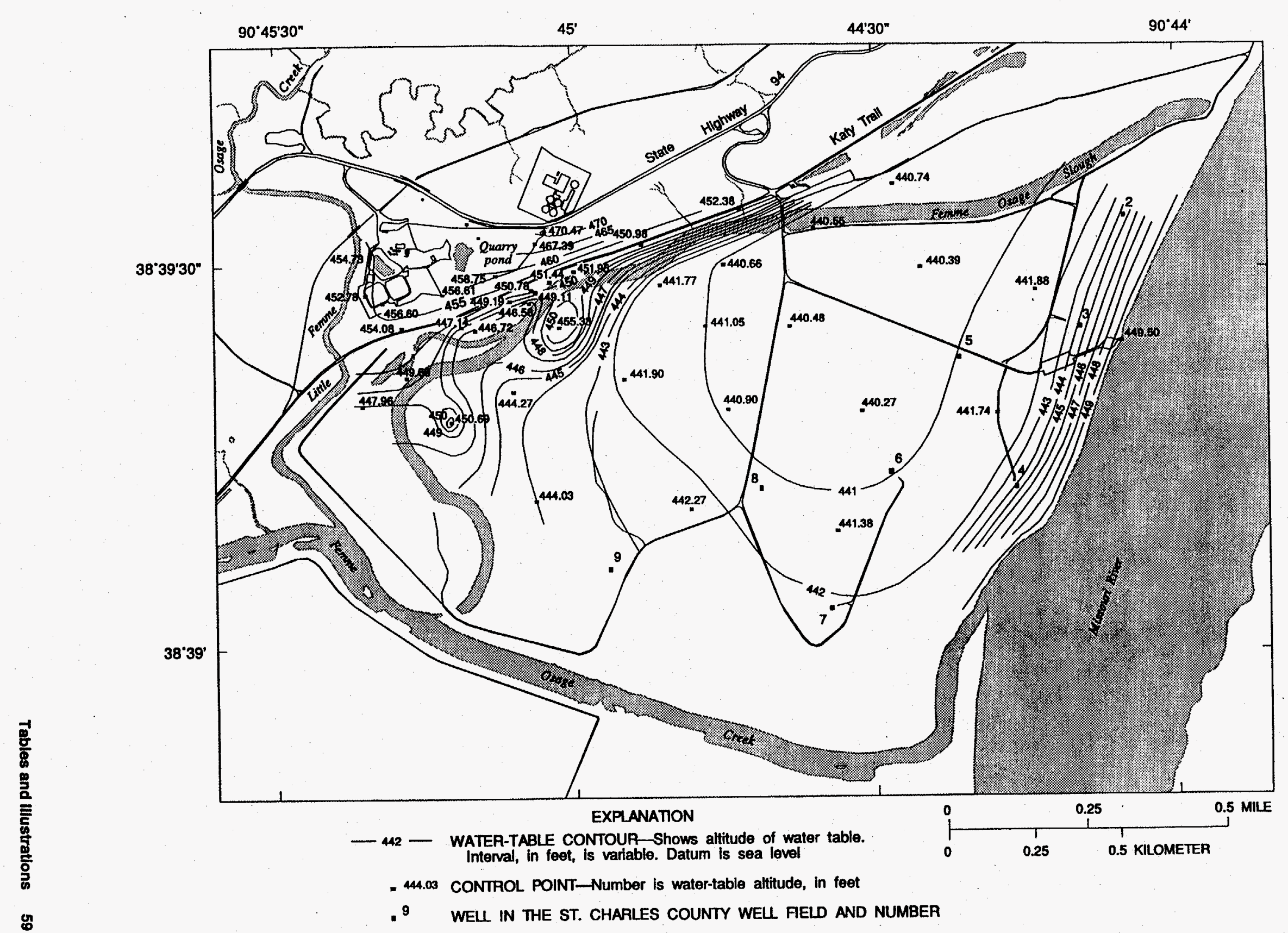

Figure 9. Water-table altitudes in the bedrock and the alluvial aquifer near the Weldon Spring quarry, November 1994. 


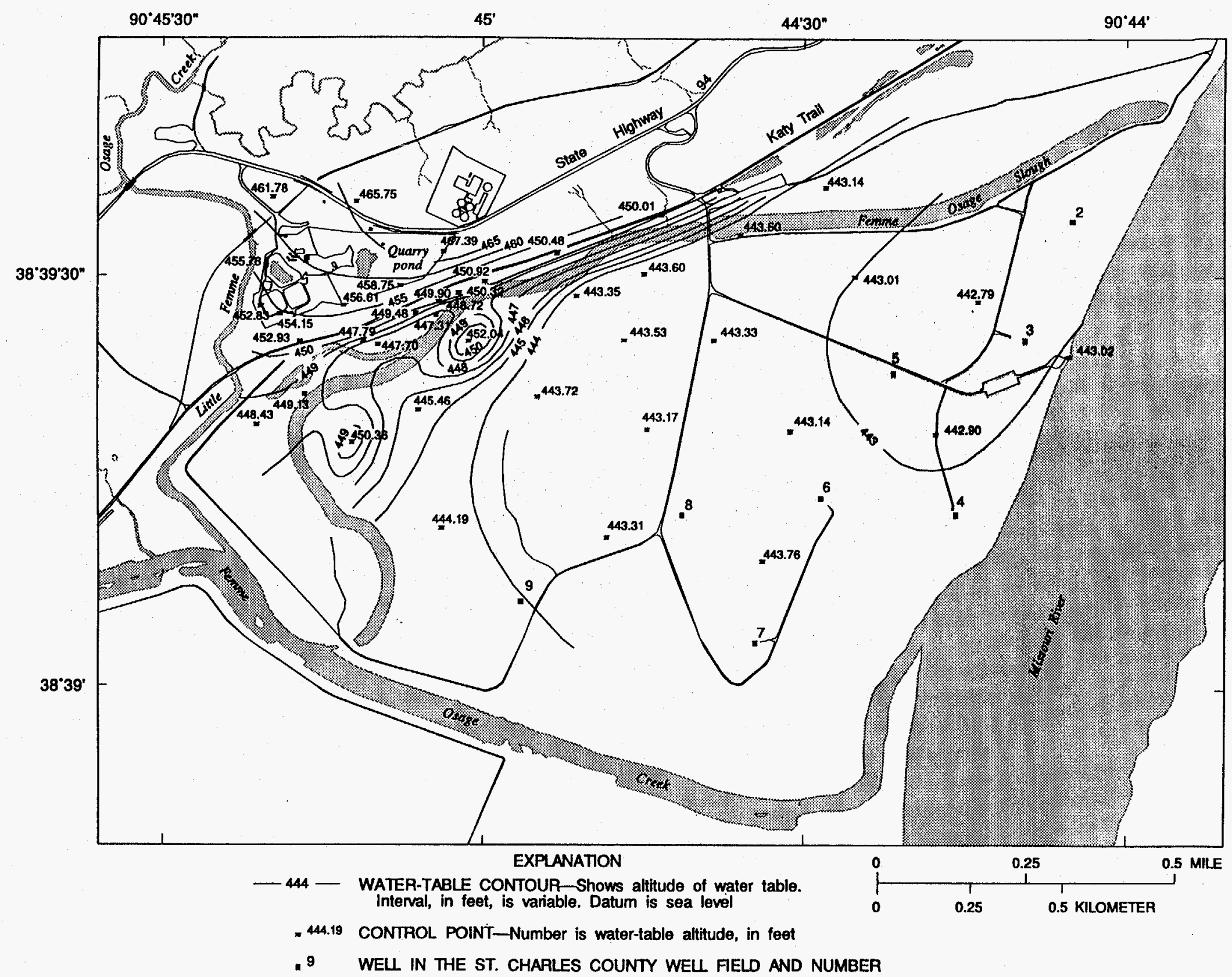

Figure 10. Water-table altitudes in the bedrock and the alluvial aquifer near the Weldon Spring quamy, December 1994. 


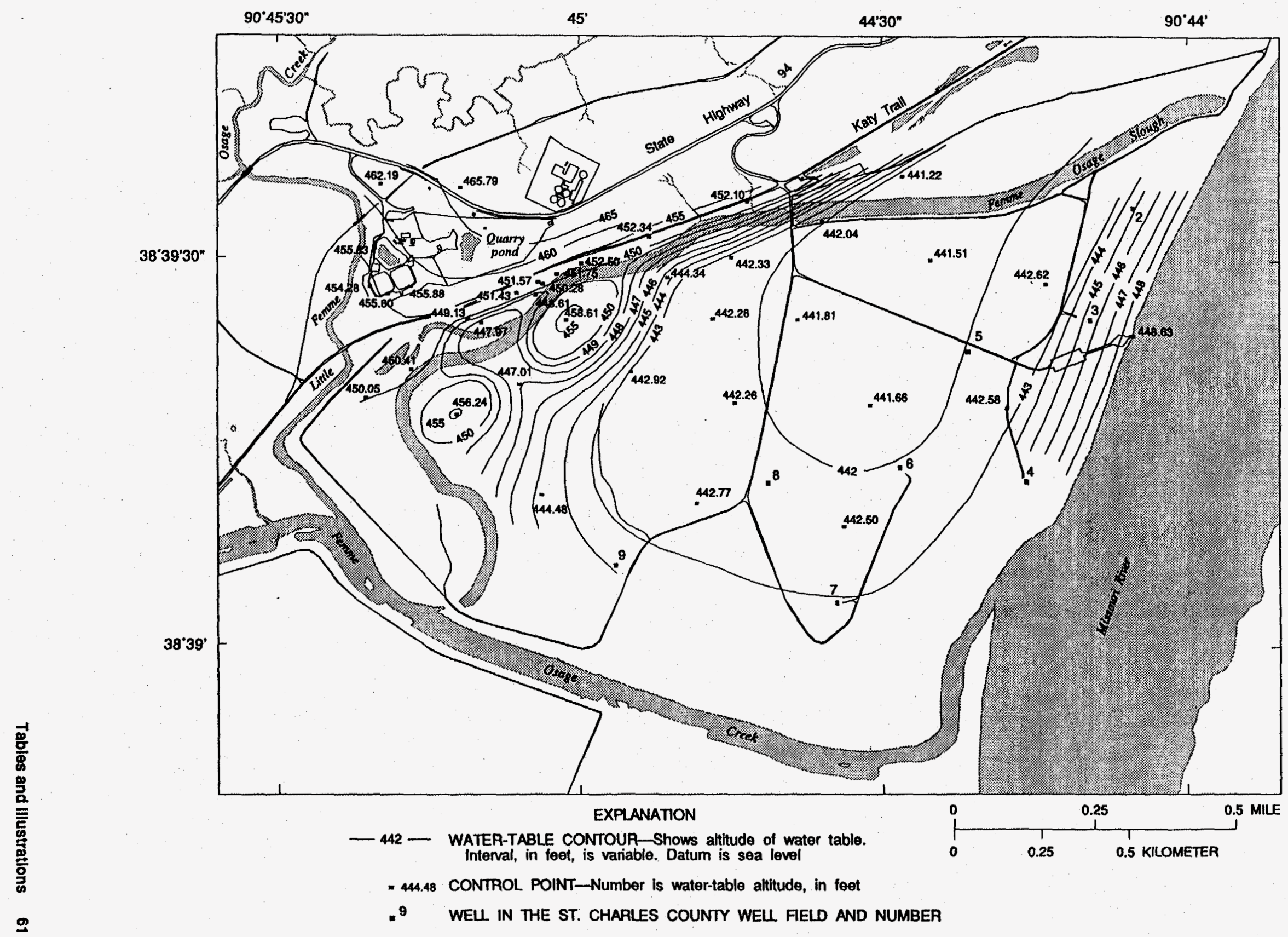

Figure 11. Water-table altitudes in the bedrock and the alluvial aquifer near the Weldon Spring quary, January 1995. 


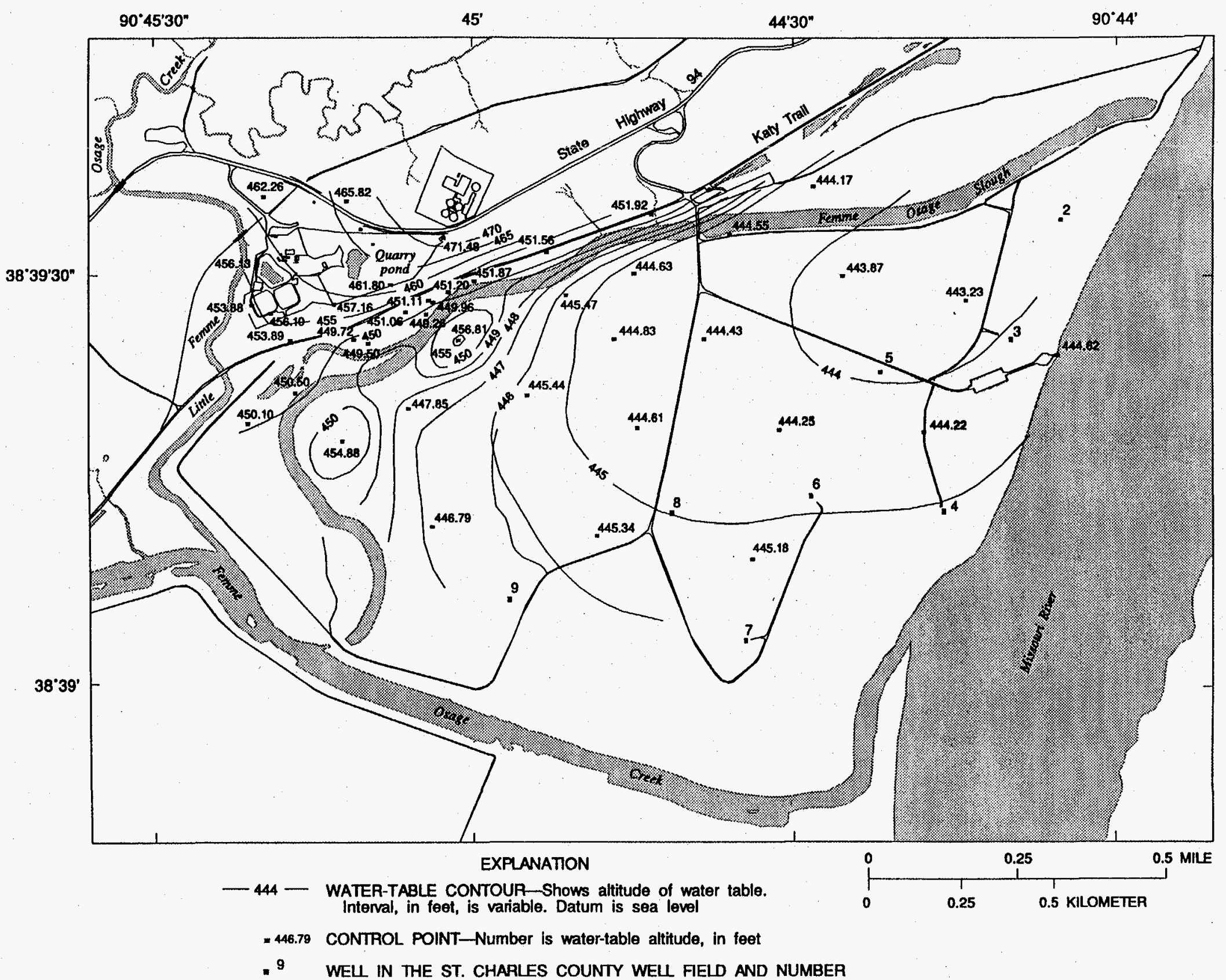

Figure 12. Water-table altitudes in the bedrock and the alluvial aquifer near the Weldon Spring quary, February 1995. 


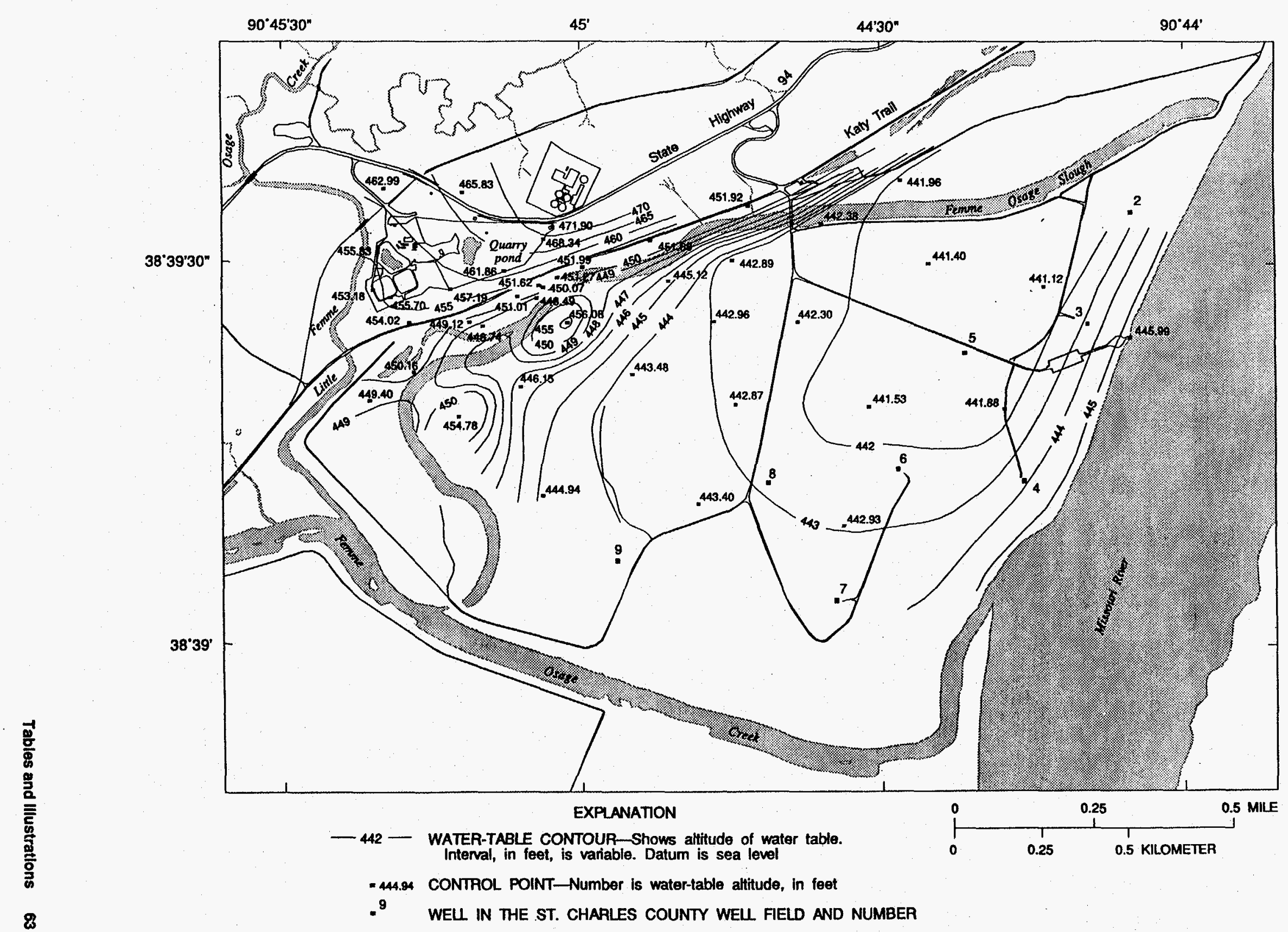

Figure 13. Water-table altitudes in the bedrock and the alluvial aquifer near the Weldon Spring quarry, March 1995. 


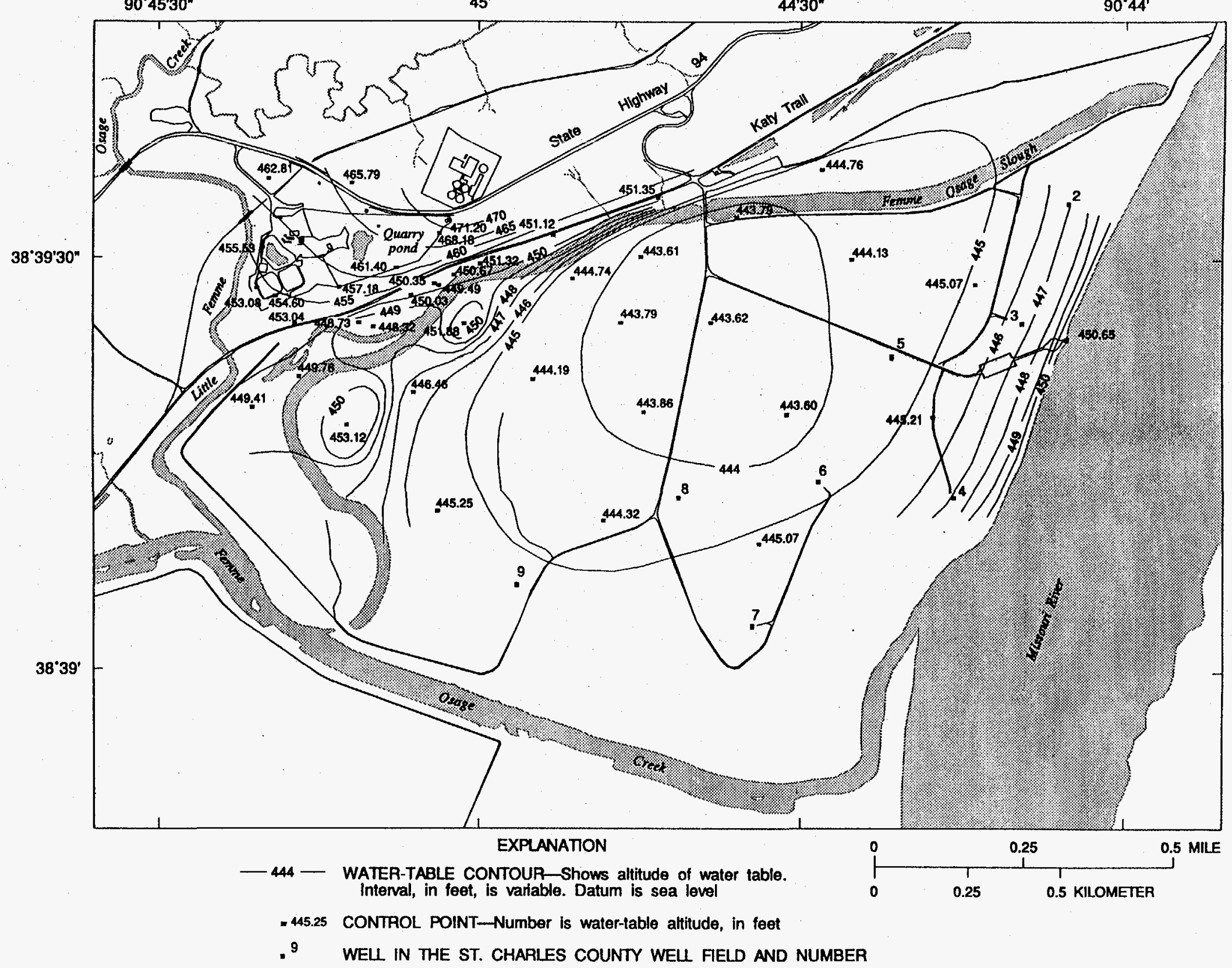

Figure 14. Water-table altitudes in the bedrock and the alluvial aquifer near the Weldon Spring quarry, April 1995. 


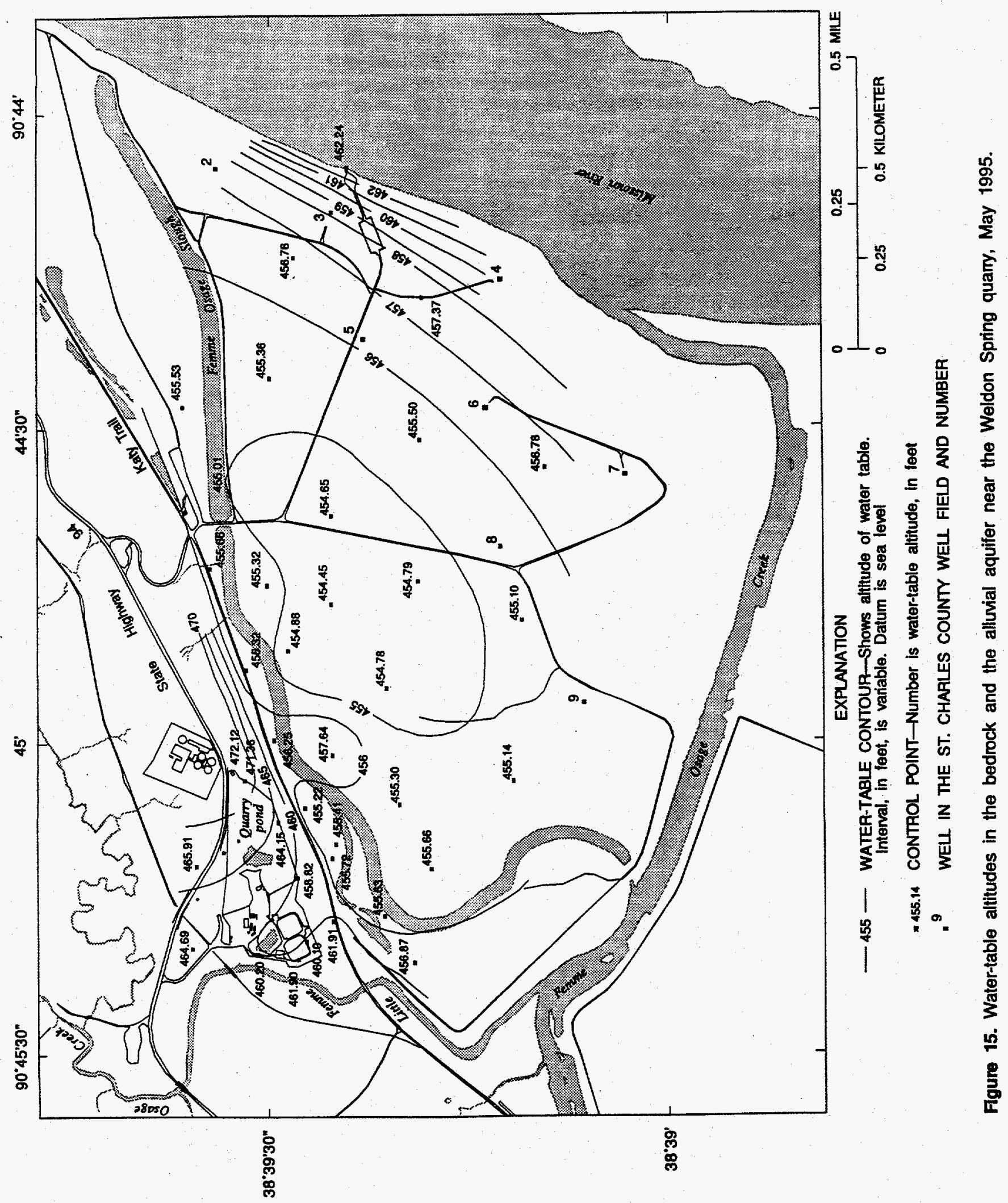




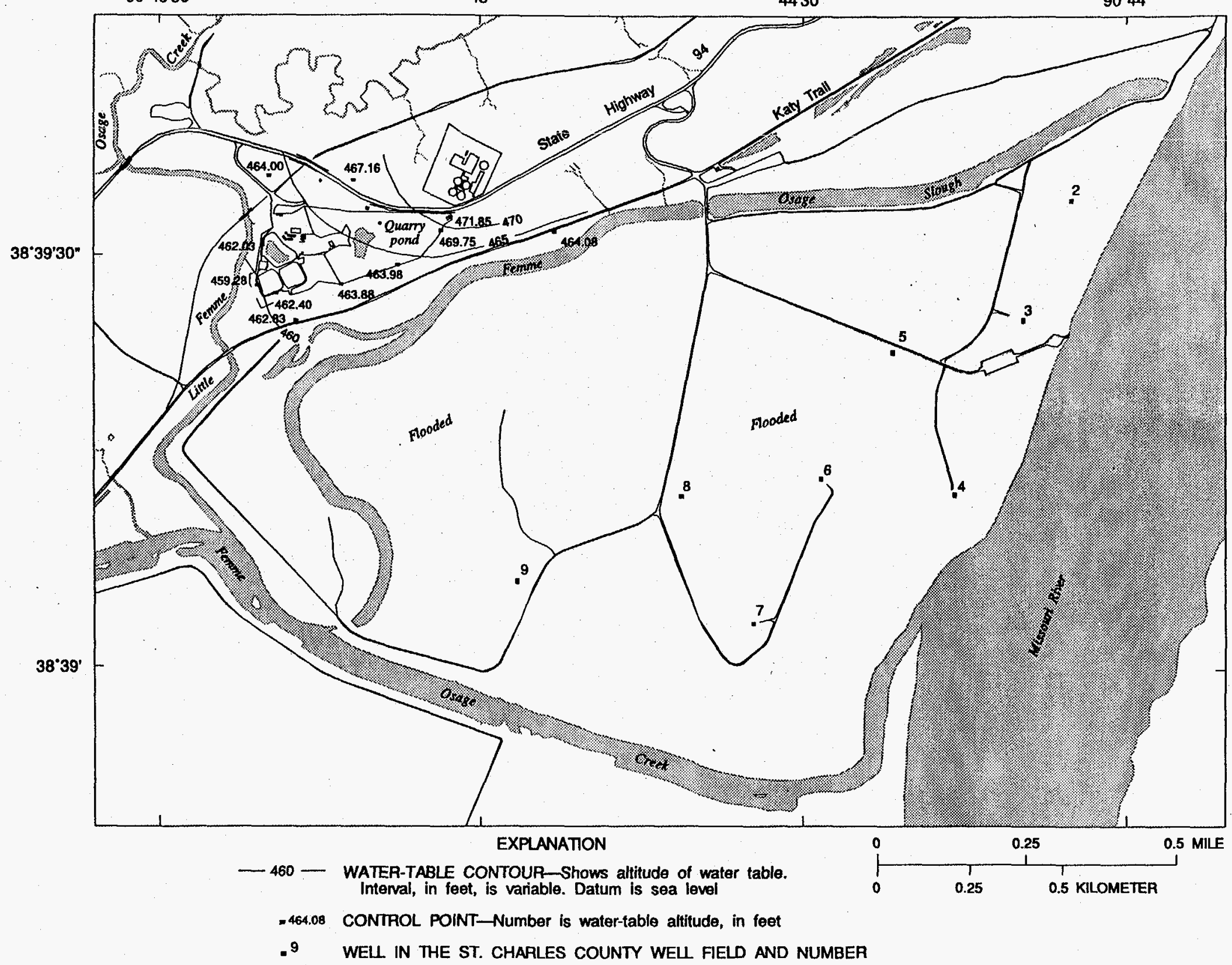

Figure 16. Water-table altitudes in the bedrock and the alluvial aquiter near the Weidon Spring quary, early July 1995. 


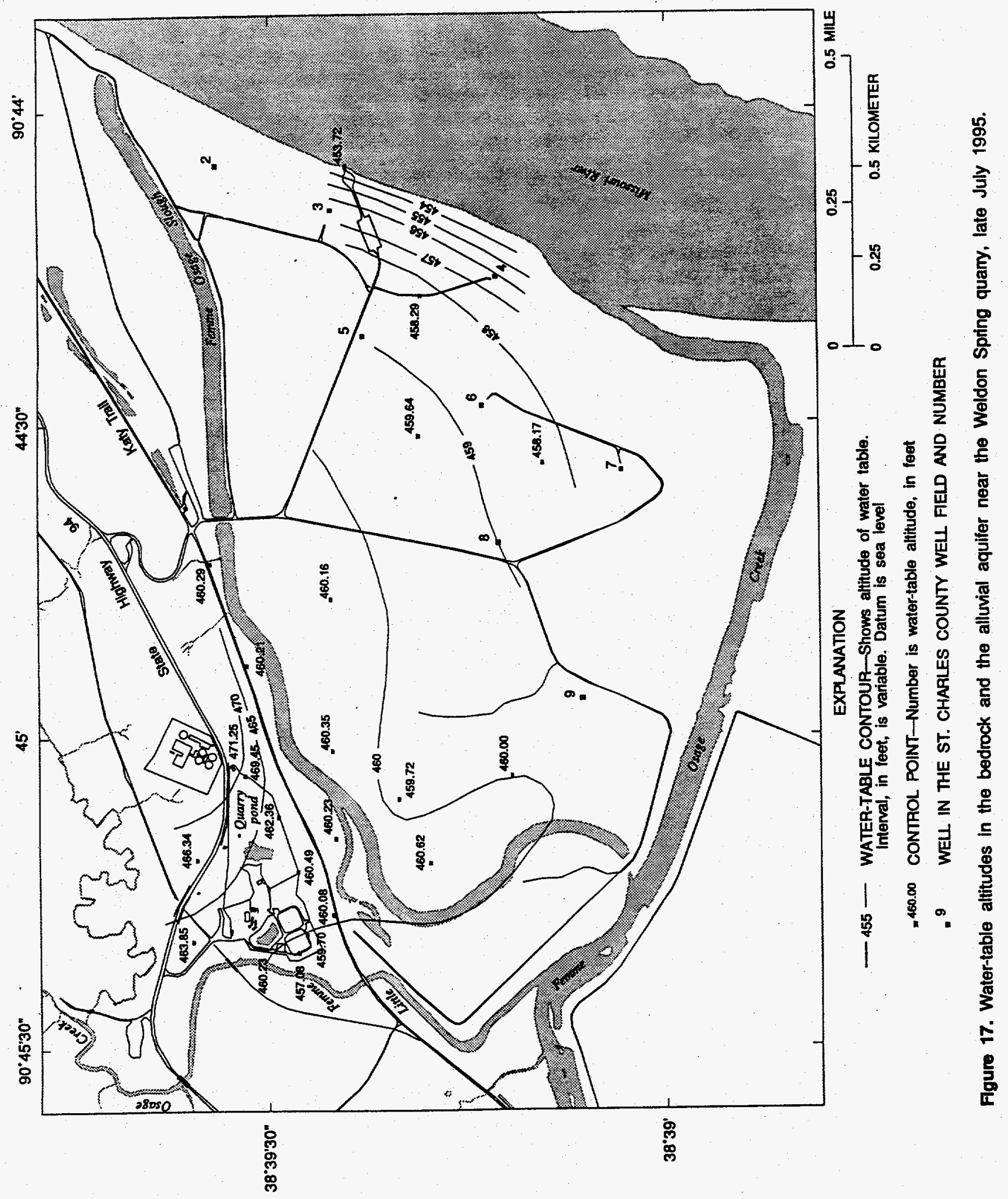




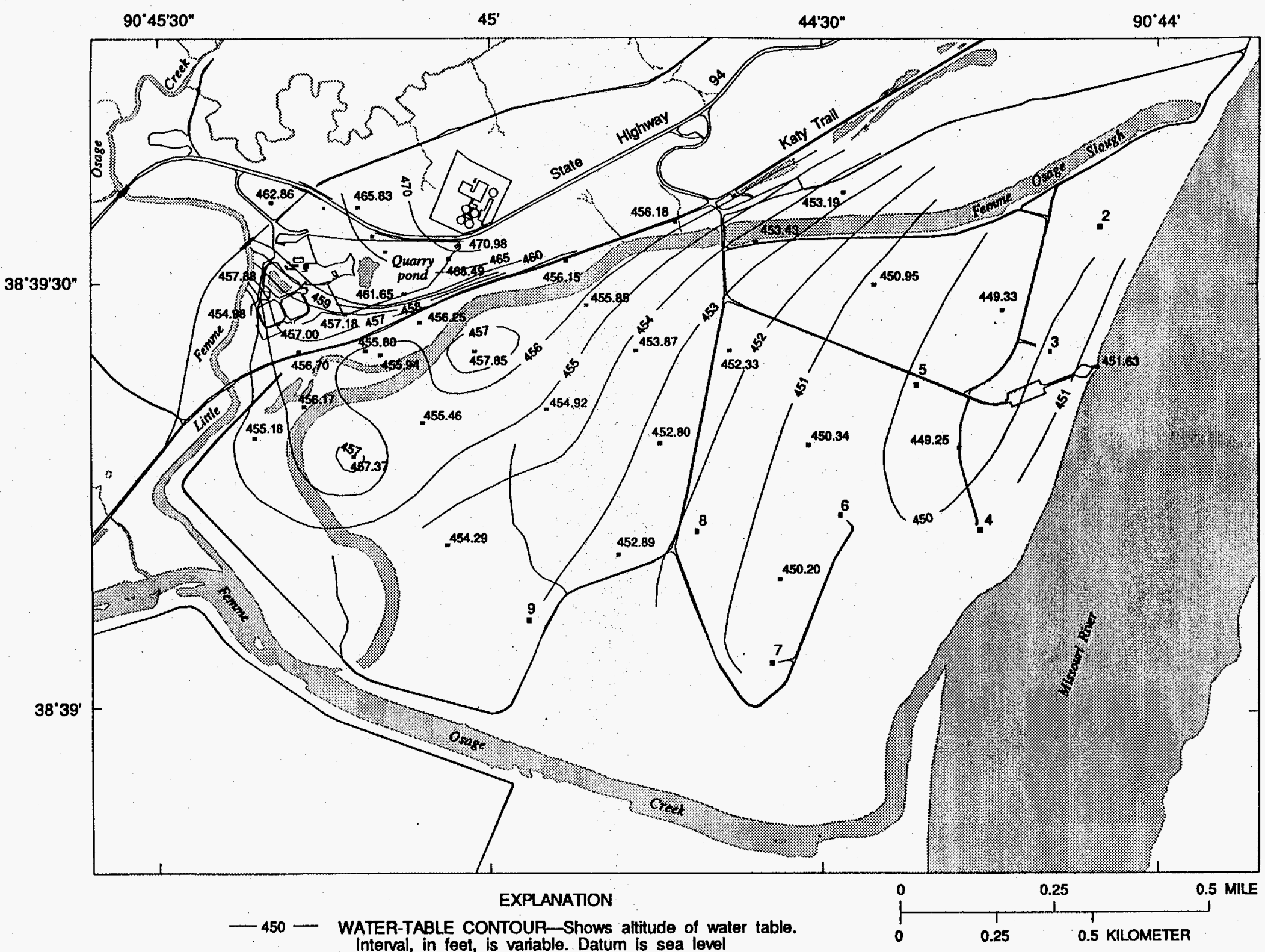

- 454.29 CONTROL POINT-Number is water-table altitude, in feet

9 WELL IN THE ST. CHARLES COUNTY WEL FIELD AND NUMBER

Figure 18. Water-table altitudes in the bedrock and the alluvial aquifer near the Weldon Spring quarry, August 1995. 


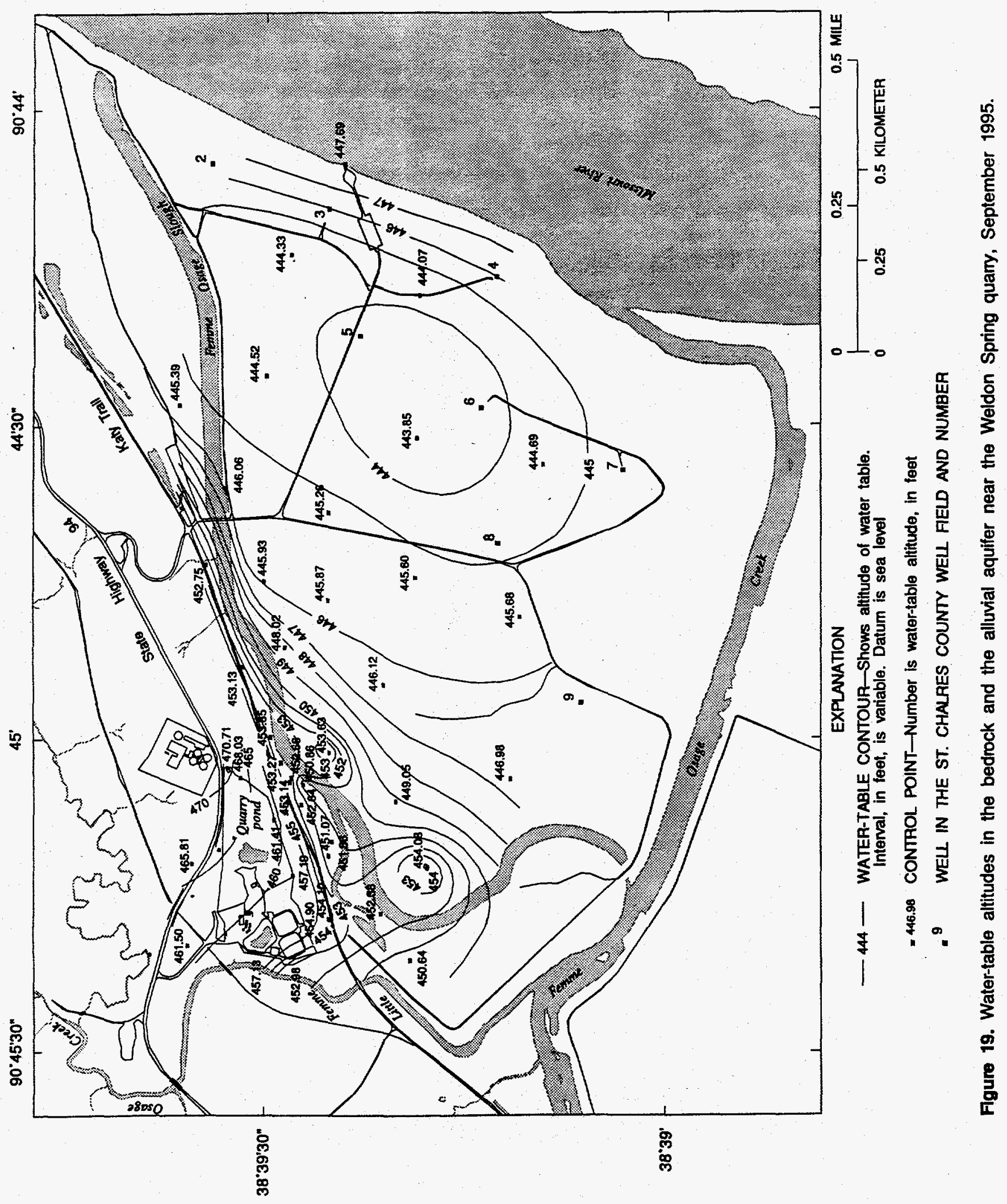




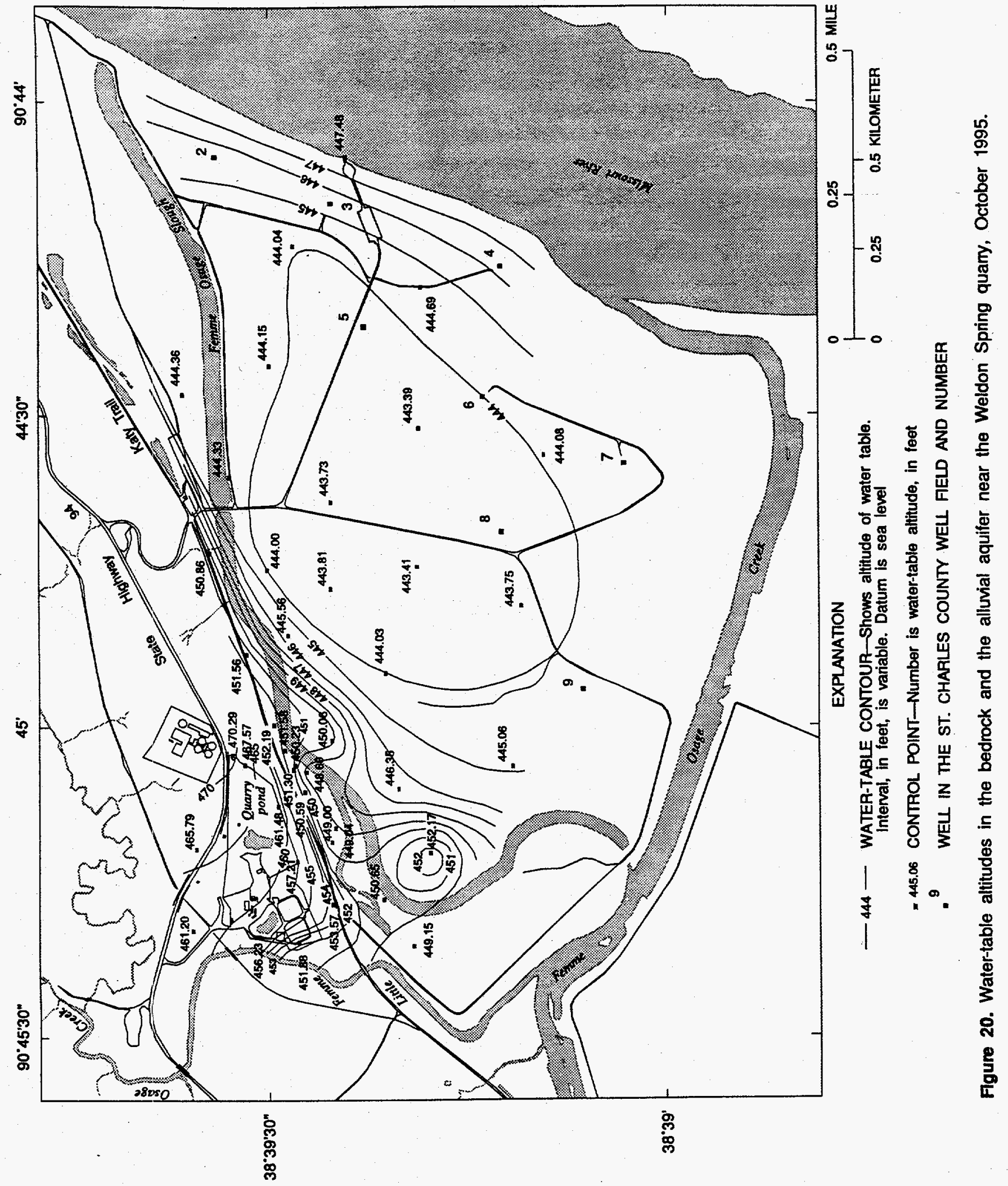




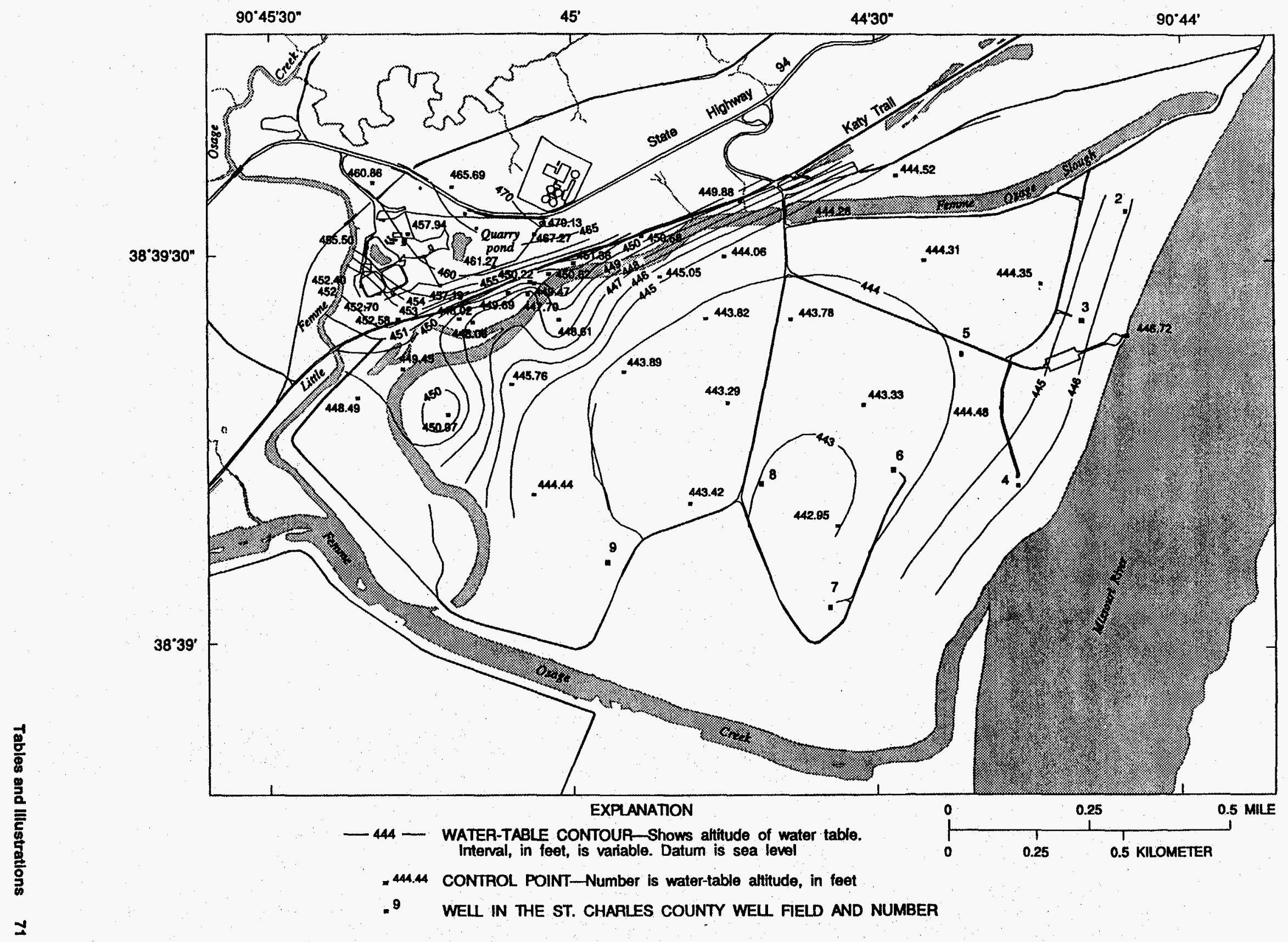

Figure 21. Water-table altitudes in the bedrock and the alluvial aquifer near the Weldon Spring quarry, December 1995. 


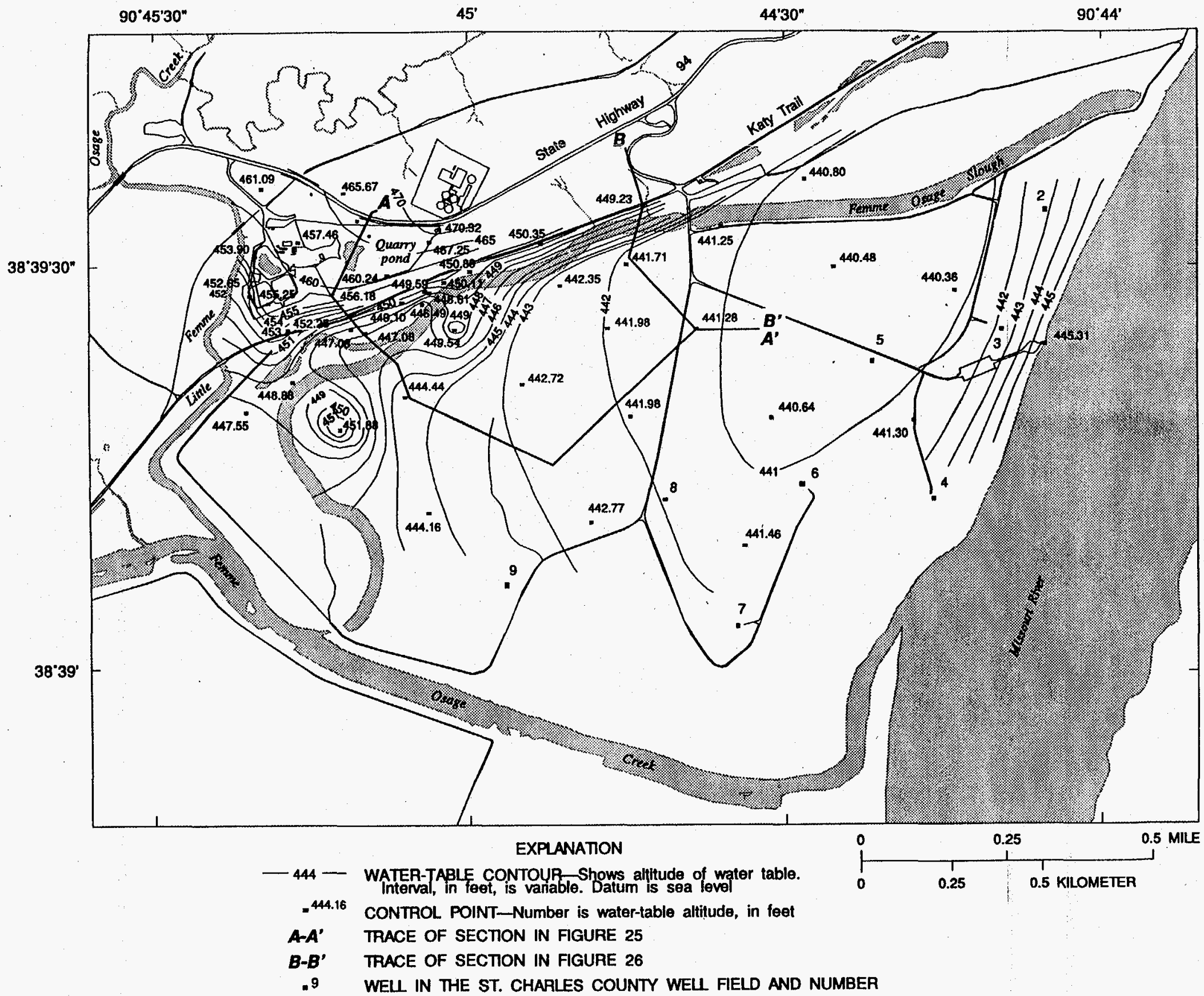

Figure 22. Water-table altitudes in the bedrock and the alluvial aquifer near the Weldon Spring quary, February 1996. 